\title{
MODUL PERKULIAHAN
}

$$
\text { GER DAN }
$$

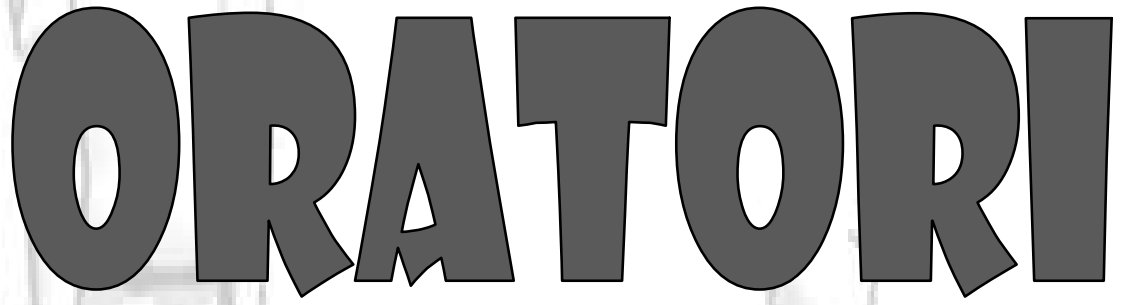




\section{BAB I \\ ORATORI}

DESKRIPSI

Materi oratori berkaitan dengan penjelasan mendasar mengenai keterampilan oratori, menjadi seorang orator, unsur-unsur yang turut mendukung keterampilan komunikasi oratori, dan hubungan antara oratori dengan seni pertunjukan.

\section{MANFAAT}

Manfaat materi ini adalah agar mahasiswa dapat memahami konsep tentang oratori dan hubungan terapannya dalam seni pertunjukan.

TUJUAN INSTRUKSIONAL KHUSUS

Setelah memahami materi ini, mahasiswa dapat 1) memahami konsep dasar oratori, 2) memahami keterampilan dasar seorang orator, 3) dan memahami hubungan antarak keterampilan oratori dan seni pertunujukan.

\section{ORATORI}

Oratori adalah ilmu bertutur di muka umum. Beberapa rujukan menyejajarkan oratori dengan hal-hal terkakit ilmu berpidato hingga retorika. Bagaimanapun, setiap istilah perlu dibedakan dan dikenali batasam-batasannya agar tidak bercampur aduk dan dapat mengaburkan konsep tunggalnya. Oratori sebagai ilmu merujuk pada ilmu-ilmu yang mengkaji seluk beluk manusia atau individu dalam bertutur di muka umum. Di dalamnya, oratori menjelaskan berbagai 
aspek yang mempengaruhi proses berbicara di muka umum. Di antaranya adalah pesan, pewicara / penutur, dan cara bertutur.

Di samping sebagai ilmu, oratori adalah sebuah kecakapan. Sebagai kecakapan, oratori tentunya merujuk pada kemampuan atau keterampilan seseorang dalam bertutur di depan umum. Kecakapan ini dibutuhkan oleh seorang pewicara publik, atau orang yang melakukan kegiatan wicara di depan umum atau publik. Pada perkembangannya, makna oratori meluas dan merujuk pada semua kegiatan (baik tuturan ataupun bukan) yang dilakukan oleh seseorang di depan umum untuk tujuan tertentu. Selanjutnya, penulis menetapkan orator untuk menyebut orang yang menerapkan keterampilan-keterampilan menyampaikan pesan di muka publik.

\section{ORATORI, RETORIKA, DAN STILISTIKA}

Di atas telah dijelaskan secara singkat tentang oratori sebagai sebuah ilmu tentang bertutur di muka umum. Kemudian, pengertian oratori diperluas pengertiannya dengan segala keterampilan dalam mengampaikan sesuatu (baik lisan maupun gerak, atau keduanya) di depan umum. Sejalan dengan oratori, retorika juga membahas tentang ilmu bertutur di muka umum. Maka keduanya seringkali dianggap sama dan dapat saling menggantikan. Namun, yang membedakan oratori dari retorika adalah rincian aspek yang dikajinya. Jika oratori mengkaji kegiatan yag secara umum dilakukan di depan publik, retorika secara khusus mengkaji kebahasaan dan penggunaan fungsi-fungsi kebahasaan dalam kegiatan bertutur di muka umum.

Retorika sebagai sebuah kecakapan di muka umum adalah kecakapan dalam menggunakan bahasa dan fungsi-fungsi kebahasaan tertentu untuk menyampaikan isi tuturan secara efektif. Sebuah tuturan yang disampaikan oleh orator, menurut Aristoteles, secara retorik dapat dikatakan efektif jika : a) menampilkan kebenaran dan b) disiapkan dan ditata secara ilmiah. Efektifitas tuturan umum tidak hanya menyangkut persoalan tersampaikan dan terpahaminya pesan penutur. Lebih dari itu, tuturan retorik memuat tujuan-tujuan seperti persuasi, politik, provokasi, mempengaruhi pikiran, dan lain sebagainya. Tujuan tersebut dirangkum sebagai feedback audien atas persepsinya terhadap kebenaran tuturan penutur. 
Pada intinya, tuturan yang retoris ini memanipulasi perilaku audien melalui bahasa yang disampaikannya.

Upaya manipulasi publik oleh seorang penutur tuturan retoris seperti orator didukung dengan gaya yang kemudian dapat kita kenali dengan sebutan stilistika (dari kata style). Melalui stilistika, gaya bahasa dan berbahasa seorang orator diulas secara jelas. Hal ini memungkinkan kita untuk mengetahui bagaimana usaha seorang orator sebagai penutur bahasa retoris untuk memilih, memilah, dan mengonstruk satuan-satuan ujaran yang dapat 'memikat' pikiran audiennya. Pada dasarnya, stilistika mengacu pada bentukan gaya bahasa untuk tujuan estetik. Melihat bagaimana seorang orator mengonstruk sebuah bahasa yang indah dan nyaman untuk didengar. Namun diluar tujuan keindahan itu, keinginan penutur untuk 'memikat' pendengarnya jauh lebih menarik untuk dipahami.

Bagaimanakah kedudukan antara ketiga konsep (oratori, retorika, dan stilistika) ini? Sebagai ilmu tentang bertutur yang umum, oratori tidak hanya berkutat pada bagaimana wujud eksternal dan fisik seorang orator. Retorika dan stilistika juga menjadi bagian perhatiannya. Seorang orator sebagai pewicara publik perlu untuk memahami kebahasaan dan fungsi-fungsi kebahasaan untuk dapat 'dipandang' dan 'didengar' oleh audiennya. Selain itu, gaya bertutur yang khas dan penuh makna juga akan turut memperkuat posisiya sebagai orator.

\section{UNSUR-UNSUR ORATORI}

Secara umum, oratori secara tepat berkaitan dengan kecakapan dalam mengatur mimik wajah, gestur, bahasa, dan gaya bertutur dalam menyampaikan sesuatu di depan publik. Setiap unsur ini memiliki peran masing-masing yang sangat penting dalam menciptakan citraan bagi publik yang dihadapinya. Bagaimana publik menilai dan meresepsi maksud seorang pewicara (misalnya), dipengaruhi oleh citra yang diterima oleh audien. Apakah citra tersebut harus baik? Bagaimana jika seorang orator tidak dalam kondisi yang baik? Akankah dia memasang 'topeng' di depan udiennya?

Mimik wajah atau facial expression merujuk pada gambaran fisik yang ditampilkan oleh wajah orator dalam menyampaikan tuturan. Secara wajar, seseorang akan menampilkan ekspresi wajah yang sesuai dengan pikiran dan 
perasaannya. Mungkin inilah yang harus diperhatikan seorang pewicara publik. Berbicara di depan publik dapat menjauhkan seseorang dari sebuah kewajaran. Hal ini dikarenakan wicara publik adalah kegiatan yang ditata sedemikian rupa sesuai dengan tujuan berwicara. Dengan begitu, apakah seorang orator akan memperlihatkan ekspresi wajah yang sewajarnya? Ataukah hanya terlihat wajar dalam subjektifitas umum, yang berarti tersenyum ramah?

Gestur atau kinetical expression adalah gambaran fisik sikap kinetik yang ditunjukkan seorang orator dalam bertutur di muka umum. Seperti halnya mimik wajah, secara wajar,seseorang akan menampilkan ekspresi kinetik yang sesuai dengan kondisi psikologisnya. Ketika seseorang menyampaikan sesuatu di depan publik, nervous system pada alam bawah sadarnya akan bereaksi terhadap perhatian semua mata audien di depannya. Dengan begitu, aliran darah, denyut nadi dan jantung, asam lambung, dan bagian-bagian tubuh lain akan bereaksi terhadap perubahan psikis ini. Utamanya jika orator tersebut belum berpengalaman dalam melakukan wicara di depan publik. Reaksi fisik akibat kondisi psikis akan berlangsung cukup lama pada masa berwicara dan menyebabkan pula hilangnya kontrol orator terhadap gerakan anggota tubuhnya. Seperti yang sering kita lihat, seorang orator seringkali menggerakkan tangan, kepala, bahu, dan kakinya bahkan hingga pada intensitas yang berlebihan atau diluar kebutuhan. Hal ini menandakan bahwa dirinya tidak pada kondisi psikis yang baik. Selanjutnya, bagaimana orator dapat mengatasi permasalahan ini? Pastinya, tidak ada audien yang merasa nyaman dengan gerakan-gerakan pewicara yang dirasa berlebihan. Meski disebut sebagai audien, bukankah mereka juga memperhatikan?

Bahasa adalah alat verbal-auditori yang digunakan orator dalam menyampaikan pesan. Secara wajar, seseorang orator menggunakan bahasa sesuai dengan keperluan informasi atau proposisi yang ingin disampaikannya. Seorang orator atau pewicara publik jelas tidak dalam kondisi yang wajar atau biasa. Komunikasi publik yang dilakukan oratot memiliki muatan yang lebih dari sekedar informasi representatif, apa yang diucapkan adalah apa yang dimaksud dalam arti sesungguhnya. Proposisi tuturan orator diikuti oleh banyak tujuan, setidaknya untuk dapat dipercaya. Maka, sistematika lokusi, ilokusi, dan perlokusi nya jelas tidak dalam alur yang sewajarnya. Tindak direktif mungkin akan diterima sebagai tindak komisif bergantung pada konteks dan cara bertutur orator, dan mungkin 
memang begitulah tujuan tuturannya. Bagaimana? Apakah dengan begini anda masih berpikir bahwa orang yang bertutur di muka umum benar-benar menyatakan kebenaran?

Terakhir, bahasa tidak menjadi berguna jika hanya diujarkan secara datar. Untuk menciptakan citra atas dirinya, orator perlu menggunakan seperangkat gaya bertutur tertentu. Pada umumnya, gaya bertutur digunakan sebagai alat supralingual untuk tujuan estetika. Namun dalam hal berwicara di depan umum, gaya bahasa bukan sekedar mendukung keindahan tuturan. Gaya bertutur dapat digunakan sebagai alat untuk menarik perhatian audien, memikat perhatian dan pikiran mereka. Selain itu, jika mencoba mengembalikan bahasa oratori pada unsur retorika, maka gaya bertutur akan menemukan tempatnya untuk melengkapi gaya bahasa / stilistika, kebenaran, intelegensia, dan kepentingan informasi. Bukankah anda hanya akan mendengar dan membenarkan kata-kata seorang orator yang 'terlihat meyakinkan' dalam bertutur?

\section{FUNGSI KOMUNIKASI EFEKTIF DALAM ORATORI}

Dalam bertutur untuk menyampaikan pesan verbal, penting bagi seorang orator untuk mengetahui efektifitas komunikasi yang dilakukannya dengan audien. Komunikasi efektif dimulai dengan memahami terlebih dahulu bagaimana proses komunikasi terlaksana. Untuk mendeskripsikan proses komunikasi, kita dapat memahami bagan alur model SCMR di bawah ini. proses komunikasi dimulai dari seorang sender (penyampai) atau penutur, message (pesan) atau proposisi tuturan, channel (saluran) atau perantara atau penyalur pesan, dan receiver (penerima) pesan arau audien.

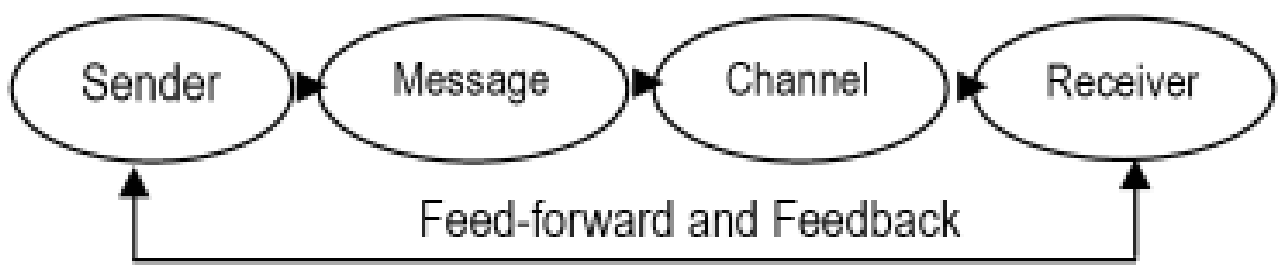


Penutur adalah orang yang menyampaikan pesan, informasi, atau proposisi tuturan. Dialah awal dari runtutan proses komunikasi. Seorang penutur harus memahami enam variabel penting yang harus diperhatikan ketika berkomunikasi dengan orang lain. Keenam variabel tersebut adalah : sender's communication skills (kemampuan berkomunikasi penutur), sender's attitudes (sikap penutur), sender's knowledge level (tingkat pengetahuan penutur), sender's social position (posisi sosial penutur), sender's culture (budaya penutur), dan feedback received by sender (penerimaan umpan-balik oleh penutur). Setiap variabel berpengaruh terhadap pengiriman dan penerimaan pesan.

\section{PESAN}

Pesan adalah segala hal yang ingin disampaikan secara kognitif oleh penutur kepada pendengarnya. Pesan terdiri atas tiga komponen yaitu konten, konteks, dan treatment (perlakuan). Konten sederhananya adalah apa yang ingin dikomunikasikan penutur. Konteks menyangkut adaptasi penyaian penutur pada konten yang dimiliki audien. Konten audien dapat berupa tujuan mereka untuk mengikuri proses komunikasi yang dibuka oleh penutur. Perlakuan adalah perencanaan atau permintaan konten oleh setiap anggota komunikasi (baik penutur maupun audien). Dengan mengondisikan ketika komponen pesan ini, maka segala hal yang ingin disampaikan secara kognitif dapat dipersiapkan dengan baik oleh penutur, disampaikan, dan pada akhirnya diterima dan diresepsi oleh penerima pesan.

\section{PERANTARA}

Channel (saluran) atau perantara atau penyalur pesan adalah seperangkat hal yang dapat digunakan penutur untuk menyampaikan pesan. Ada dua tipe perantara yang saling berkaitan yaitu sensory channel (perantara sensori) dan institutional channel (perantara institusional / instrumental). Perantara sensori didasarkan pada kelima pengindera yaitu penglihatan, pendengaran, merabaan, 
penciuman, dan pencecap. Seorang penutur akan mendapatkan atensi penuh penerimanya jika dia telah menggunakan dua atau lebih perantara sensori dalam menyampaikan informasi. Institutional channel (perantara institusional / instrumental) adalah metode yang dipilih untuk menebarkan informasi seperti obrolan tatap-muka, materi tercetak, dan penggunaan media elektronik. Setiap media institusional memerlukan satu atau lebih saluran sensori untuk membawakan pesan. Contohnya, ketika melakukan obrolen tatap muka sebagai media, penutur membutuhkan sensori penglihatan (ekspresi, gestur), pendengaran (suara), dan mungkin sentuhan, bau, atau rasa untuk memperkuat penerimaan pesan.

\section{PENERIMA}

Penerima pesan juga harus memiliki dan menggunakan kemampuan yang sama seperti halnya penutur pesan. Keterampilan komunikasi, sikap, tingkat pengetahuan, posisi sosial, kultur / budaya, dan umpan balik, semuanya penting untuk dipahami. Lebih dari itu, penerima memiliki variabel tambahan yaitu praanggapannya terhadap kredibilitas penutur. Jika penerima pesan menganggap bahwa penutur informasi adalah orang yang kredibel, objektif, dan memiliki keahlian terkait topik yang dibicarakan, dia akan cenderung menerima segala informasi yang diberikan. Selebihnya, penutur harus memiliki keahlian atau menemukan seseorang dengan keahlian (pengetahuan) yang sama untuk mengomunikasikan pesannya.

\section{ORATORI DALAM DRAMA (UNGKAPAN KEBENARAN DI ATAS PANGGUNG)}

Pada bagian awal modul ini, kita telah memahami oratori sebagai kegiatan menyampaikan sesuatu di depan publik. Penjelasannya tentu lebih banyak mengarah pada penyampaian lisan, didukung dengan beberapa aspek nonlisan seperti ekspresi wajah dan gestur. Lalu apakah hubungan antara kemampuan oratori dengan pemeranan dalam seni pertunjukan?

Suatu kesamaan yang entig dan menjadi benang penghubung antara kemampuan oratori dan pemeranan seni pertunjukan adalah keduanya adalah bentuk kegiatan menyapaikan pesan di depan publik. Bagaimanapun, seorang aktor 
bukan sekedar boneka penaskah peran. Lebih dari itu, aktor secara aktif dan sadar mengemban tugas besar untuk menyampaikan setiap pesan penaskah pada audiennya. Denan begitu, apakah seorang aktor tidak membutuhkan kemampuan oratori untuk memperkuat penyampaian pesannya?

Selain dalam hal menyampaikan pesan di depan publik, hal oratori dalam seni pertunjukan menempatkan seseorang pada posisi fokus perhatian publik. Sebagai orang dalam perhatian publik, seorang aktor dalam seni pertunjukan tidak berada dalam kondisi yang wajar. Aktor harus mengondisikan dirinya sesuai dengan tuntutan penaskah, memosisikan dirinya sebagai pusat perhatian, dan memikat audien dengan pertunjukannya. Meski begitu, aktor harus memerankan tugasnya dengan penuh kewajaran. Wajar dalam arti sesuai dengan tuntutan naskah.

Pada akhirnya kita sampai pada sebuah penyimpulan bahwa seni pertunjukan tidak dapat dipisahkan dari keterampilan seorag orator. Aktor yang baik adalah seorang orator yang luar biasa. Di dalam diri seorang aktor, terdapat kemampuan seorang orator dalam bertutur di depan publik. Seperti halnya seorang orator, aktor memikat audien dengan tuturannya. 


\section{BAB II \\ BLOKING}

DESKRIPSI

Materi bloking atau olah gerak berisi penjelasan praktikal untuk melatih gerakan aktor oratoris. Latihan gerak bertujuan agar aktor memiliki keterampilam dalam penguasaan medan oratori (mis. Panggung) dan keleluasaan gerak di atasnya. Kemampuan aktor oratori dalam bergerak tidak semata-mata atas dasar keleluasaan, melainkan pula dasar tujuan estetika dan keseimbangan, baik dengan aktor lain maupun benda-benda properti di sekitarnya.

\section{MANFAAT}

Dengan memahami materi praktikal ini mahasiswa dapat melaksanakan praktik latihan bloking (olah gerak) dengan baik dan dengan arahan yang jelas.

\section{TUJUAN INSTRUKSIONAL KHUSUS}

Setelah memahami materi ini, mahasiswa dapat 1) memahami tata kegiatan olah gerak yang baik, 2) melaksanakan kegiatan olah gerak, dan 3) menyusun dan mengembangkan langkah kegiatan olah gerak.

\section{BLOKING}

Sutradara diwajibkan memahami cara mengatur pemain di atas pentas. Bukan hanya akting tetapi juga blocking. Secara mendasar blocking adalah gerakan fisik atau proses penataan (pembentukan) sikap tubuh seluruh aktor di atas panggung. Blocking dapat diartikan sebagai aturan berpindah tempat dari titik (area) satu ke titik (area) yang lainnya bagi aktor di atas panggung. Untuk 
mendapatkan hasil yang baik, maka perlu diperhatikan agar blocking yang dibuat tidak terlalu rumit, sehingga lalulintas aktor di atas panggung berjalan dengan lancar. Jika blocking dibuat terlalu rumit, maka perpindahan dari satu aksi menuju aksi yang lain menjadi kabur. Yang terpenting dalam hal ini adalah fokus atau penekanan bagian yang akan ditampilkan. Fungsi blocking secara mendasar adalah sebagai berikut.

- Menerjemahkan naskah lakon ke dalam sikap tubuh aktor sehingga penonton dapat melihat dan mengerti.

- Memberikan pondasi yang praktis bagi aktor untuk membangun karakter dalam pertunjukan.

- Menciptakan lukisan panggung yang baik.

Dengan blocking yang tepat, kalimat yang diucapkan oleh aktor menjadi lebih mudah dipahami oleh penonton. Di samping itu, blocking dapat mempertegas isi kalimat tersebut. Jika blocking dikerjakan dengan baik, maka karakter tokoh yang dimainkan oleh para aktor akan tampak lebih hidup.

\section{PEMBAGIAN AREA PANGGUNG}

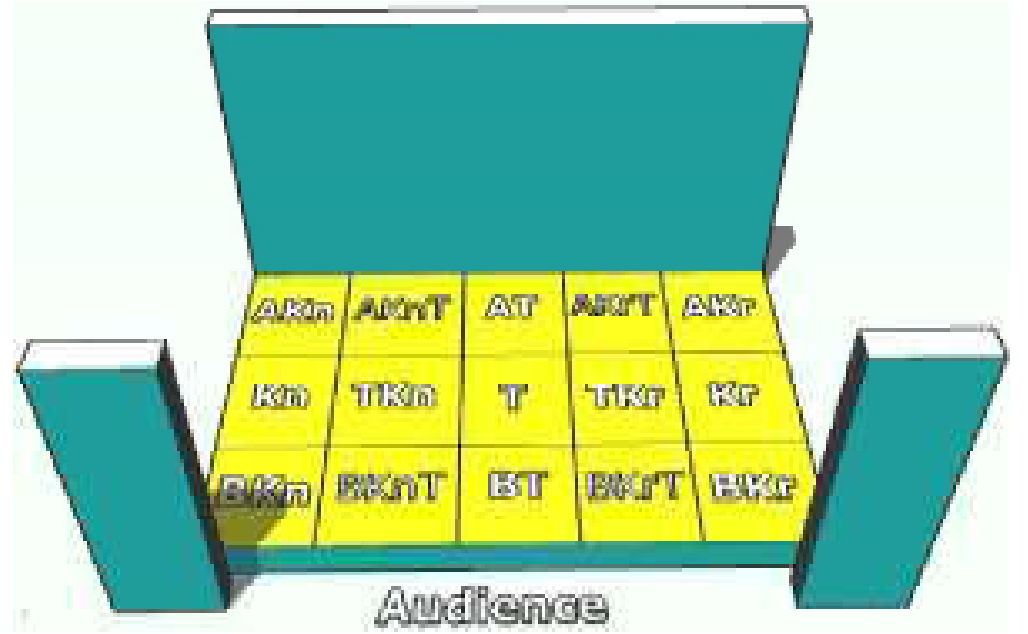

Pembagian lima belas area panggung

Akn = Atas Kanan, AknT = Atas Kanan Tengah, AT = Atas Tengah, AkrT = Atas Kiri Tengah, Akr = Atas Kiri, Kn = Kanan, TKn = Tengah Kanan, $\mathbf{T}=$ Tengah, $\mathbf{T K r}=$ Tengah Kiri, $\mathbf{K r}=$ Kiri, BKn = Bawah Kanan, BKnT = Bawah Kanan Tengah, BT = Bawah Tengah, BKrT = Bawah Kiri Tengah, BKr = Bawah Kiri 
Untuk membuat atau merencanakan blocking bagi para pemain, perlu diketahui terlebih dahulu pembagian area panggung. Panggung pertunjukan secara kompleks dibagi dalam lima belas area, yaitu tengah, tengah kanan, tengah kiri, kanan, kiri, bawah tengah, bawah kanan tengah, bawah kiri tengah, bawah kanan, bawah kiri, atas tengah, atas kanan tengah, atas kiri tengah, atas kanan, dan atas kiri. Pembagian panggung dalam lima belas area ini biasanya digunakan untuk panggung yang berukuran besar.

Letak kanan dan kiri atau atas dan bawah ditentukan berdasar pada arah hadap aktor ke penonton. Kanan adalah kanan pemain dan bukan kanan penonton dan kiri adalah kiri pemain. Atas adalah jarak terjauh dari penonton, sedangkan bawah adalah jarak terdekat dengan penonton, sedangkan kanan adalah posisi kanan arah hadap aktor atau sisi kiri penonton.

Secara sederhana dan umum panggung dibagi sembilan area, yaitu tengah, tengah kanan, tengah kiri, bawah tengah, bawah kanan, bawah kiri, atas tengah, atas kanan, dan atas kiri. Panggung yang tidak terlalu luas jika dibagi menjadi lima belas area, maka luas masing-masing area akan terlalu sempit sehingga tidak memungkinkan sebuah pergerakan yang leluasa baik untuk pemain maupun perabot. Pembagian sembilan area juga memudahkan sutradara dalam memberikan arah gerak kepada para aktornya.

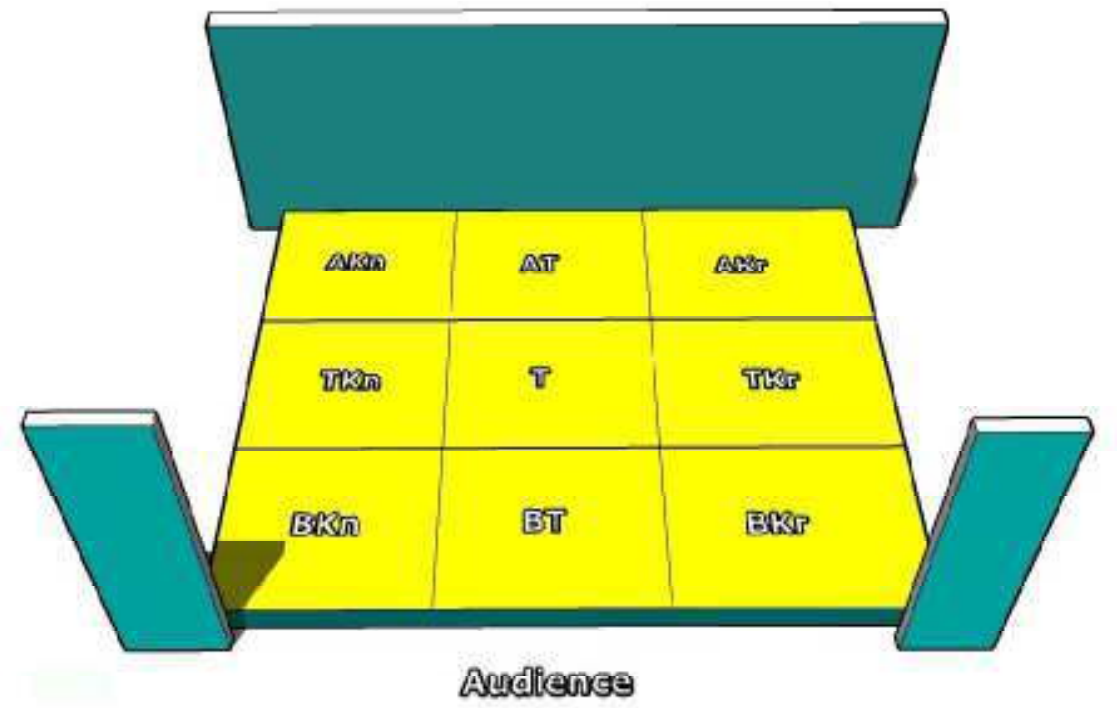

Pembagian sembilan area panggung

$\mathbf{A K n}=$ Atas Kanan, $\mathbf{A T}=$ Atas Tengah, $\mathbf{A K r}=$ Atas Kiri, $\mathbf{T K n}=$ Tengah Kanan, $\mathbf{T}=$ Tengah, $\mathbf{T K r}=$ Tengah Kiri, BKn = Bawah Kanan, BT = Bawah Tengah, $\mathrm{BKr}=$ Bawah Kiri 
Komposisi dapat diartikan sebagai pengaturan atau penyusunan pemain di atas pentas. Sekilas komposisi mirip dengan blocking. Bedanya, blocking memiliki arti yang lebih luas karena setiap gerak, arah laku, perpindahan pemain serta perubahan posisi pemain dapat disebut blocking. Sedangkan komposisi, lebih mengatur posisi, pose, dan tinggi rendah pemain dalam keadaan diam (statis). Pengaturan posisi pemain seperti ini dilakukan agar semua pemain di atas pentas dapat dilihat dengan jelas oleh penonton. Ada dua ragam komposisi pemain, yaitu komposisi simetris dan komposisi asimetris yang ditata dengan mempertimbangkan keseimbangan.

\section{KOMPOSISI SIMETRIS}

Komposisi simetris adalah komposisi yang membagi pemain dalam dua bagian dan menempatkan bagian-bagian tersebut dalam posisi yang benar-benar sama dan seimbang. Jika digambarkan komposisi ini mirip cermin. Bagian yang satu merupakan cerminan bagian yang lain. Di bawah ini adalah contoh komposisi simetris.

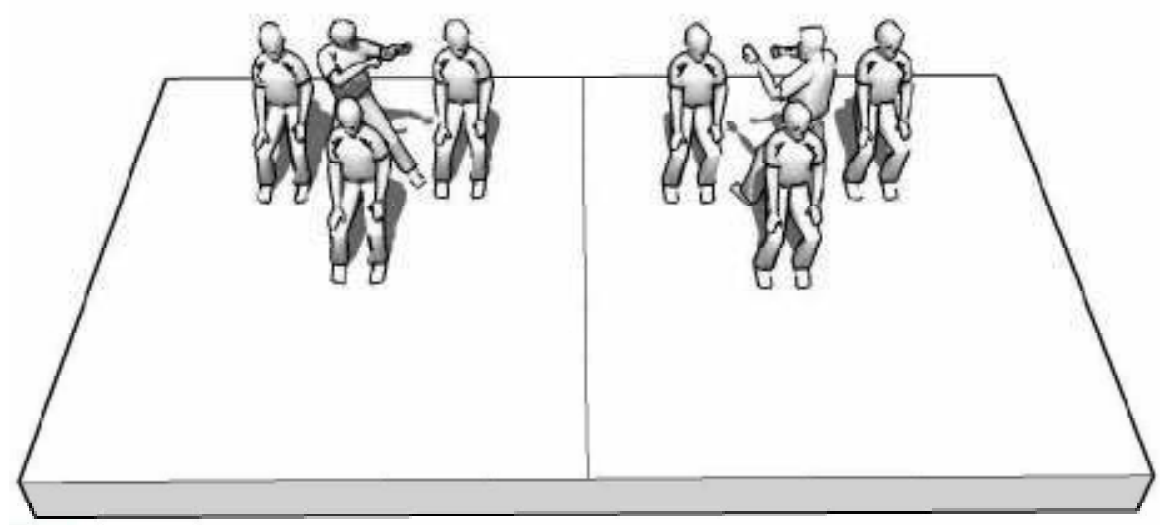

Gambar Komposisi simteris 
Komposisi asimetris tidak membagi pemain dalam dua bagian yang sama persis, tetapi membagi pemain dalam dua bagian atau lebih dengan tujuan memberi penonjolan (penekanan) bagian tertentu. Di bawah ini contoh komposisi asimetris.

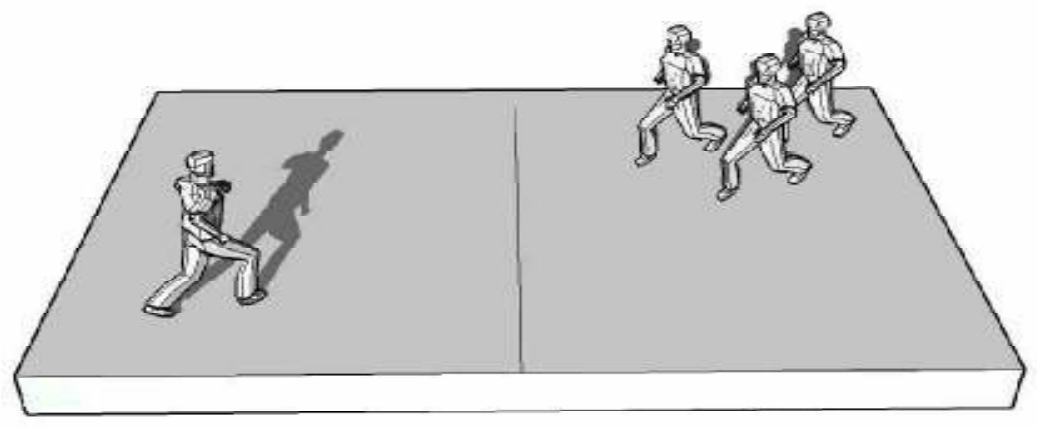

Gambar Komposisi asimetris

\section{KOMPOSISI KESEIMBANGAN}

Dalam menata komposisi pemain di atas pentas hal yang paling penting untuk diperhatikan adalah keseimbangan. Keseimbangan adalah pengaturan atau pengelompokan aktor di atas pentas yang ditata sedemikian rupa sehingga tidak menghasilkan ketimpangan. Hal ini diperlukan untuk memenuhi ruang dan menghindari komposisi aktor yang berat sebelah. Jika salah satu ruang dibiarkan kosong sementara ruang yang lain terisi penuh, maka hal ini akan menimbulkan pemandangan yang kurang menarik dan jika hal ini berlangsung lama, maka penonton akan menjadi jenuh.

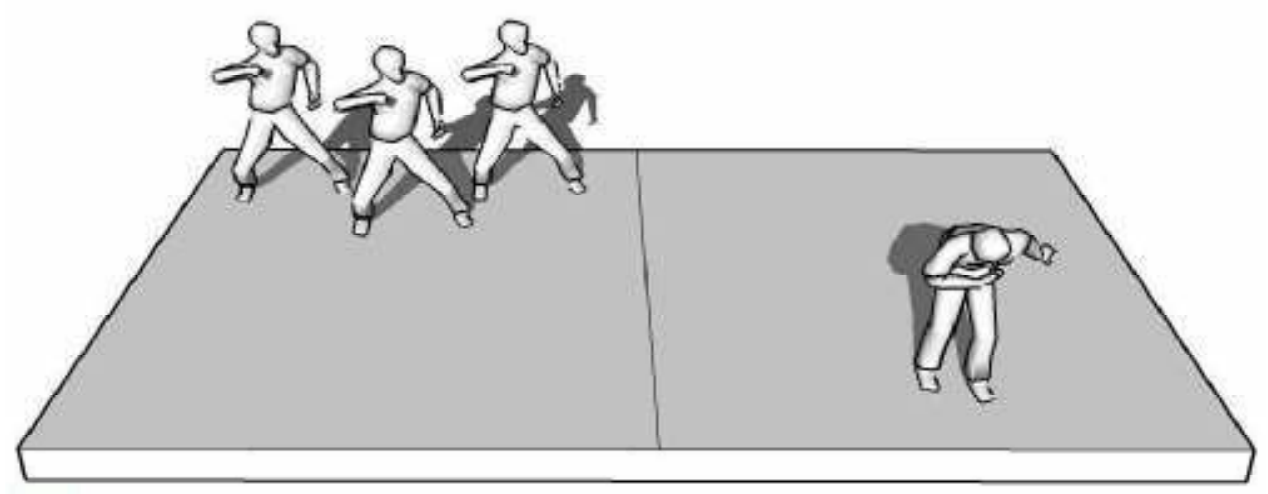

Gambar Komposisi yang seimbang 
Gambar di atas memperlihatkan komposisi yang seimbang, meskipun jumlah pemain di sisi kanan dan kiri berbeda. Jumlah pemain yang banyak diimbangi dengan pemain tunggal yang mengambil jarak dengan memanfaatkan area lain yang kosong.

Gambar di bawah memperlihatkan ketidakseimbangan komposisi karena posisi atau kedudukan pemain berat sebelah sehingga areal panggung yang lain nampak kosong. Komposisi seperti ini jika berlangsung dalam waktu yang cukup lama akan memberikan gambaran yang jelek dan membuat mata penonton lelah.

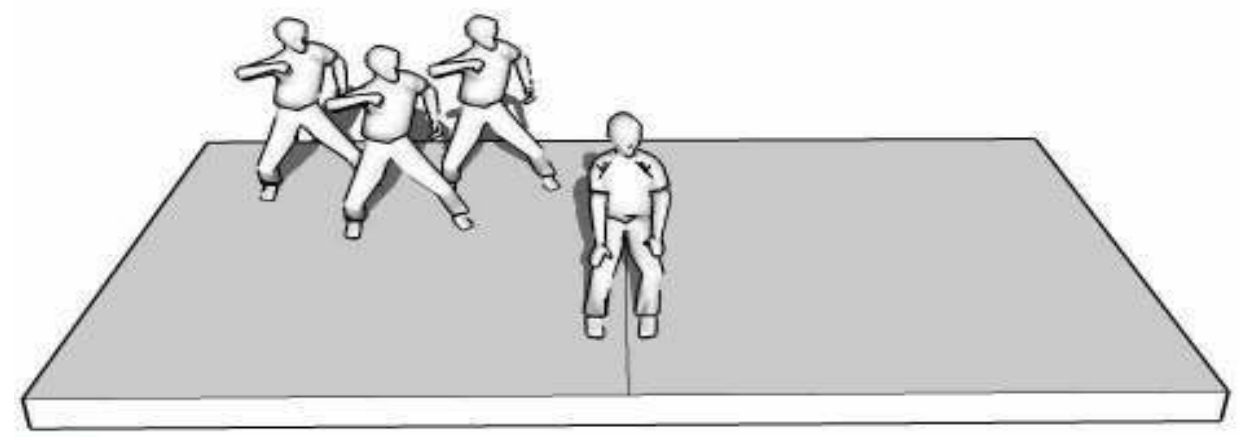

Gambar Komposisi yang tidak seimbang

\section{FOKUS}

Dalam mengatur blocking, hal yang paling utama untuk diperhatikan sutradara adalah perhatian penonton. Setiap aktivitas, karakter, perubahan ekspresi dan aksi di atas pentas harus dapat ditangkap mata penonton dengan jelas. Oleh karena itu, pengaturan blocking harus mempertimbangkan pusat perhatian (fokus) penonton. Hal ini dapat dikerjakan dengan menempatkan pemain dalam posisi dan situasi tertentu sehingga ia lebih menonjol atau lebih kuat dari yang lainnya.

\section{PRINSIP DASAR FOKUS}

Pada dasarnya fokus adalah membuat pemain menjadi terlihat jelas oleh mata penonton. Oleh karena itu, prinsip-prinsip dasar di bawah ini dapat digunakan sebagai petunjuk dalam menempatkan posisi dan mengatur pose pemain. 
- Kurangilah menempatkan pemain dalam posisi menghadap lurus ke arah penonton atau menyamping penuh. Usahakan pemain menghadap diagonal (kurang lebih 45 derajat) ke arah penonton. Menghadap lurus ke arah penonton akan memberikan efek datar dan kurang memberikan dimensi kepada pemain, sedangkan menyamping penuh akan menyembunyikan bagian tubuh yang lain. Dengan menghadap secara diagonal, maka dimensi dan keutuhan tubuh pemain akan dilihat dengan jelas oleh mata penonton. Gambar di bawah memperlihatkan pemain dengan pose menyamping, diagonal, dan ke depan. Jika diperhatikan dengan seksama, pemain dengan pose diagonal lebih memiliki dimensi dibandingkan pemain dengan pose yang lain.

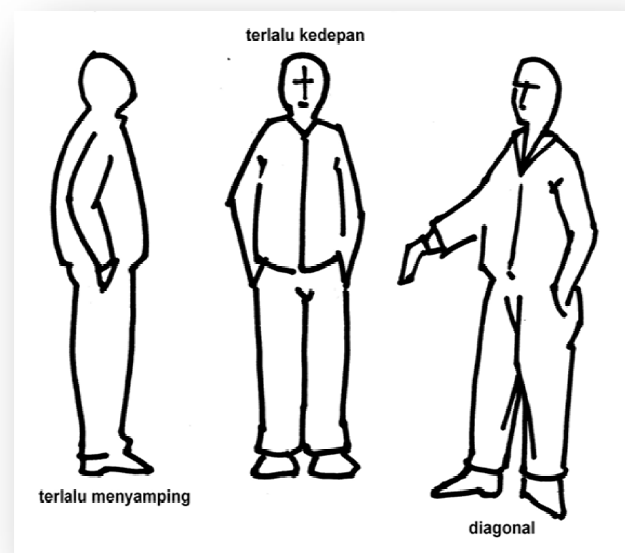

Gambar pose arah hadap pemain

- Jika pemain hendak melangkah, maka awali dan akhiri langkah tersebut dengan kaki panggung atas (yang jauh dari mata penonton). Jika melangkah dengan kaki panggung bawah (yang dekat dari mata penonton), maka kaki yang jauh akan tertutup dan wajah pemain secara otomatis akan menjauh dari mata penonton. Hal ini menjadikan gerak pemain kurang terlihat dengan jelas. Gambar di bawah memperlihatkan pemain yang melangkah menggunakan kaki panggung bawah dan kaki panggung atas. Pemain yang melangkah dengan kaki panggung atas tampak lebih luwes dan memberi keluasan pandangan bagi penonton 


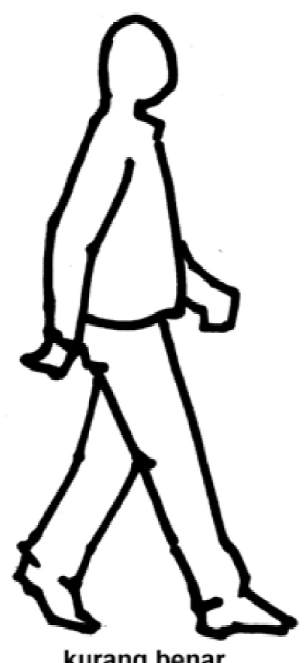

kurang benar

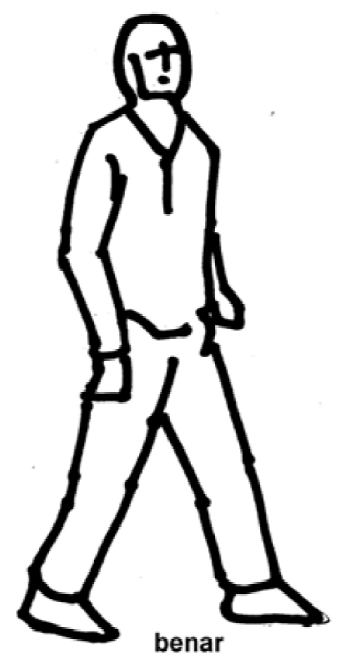

Gambar gerak langkah pemain

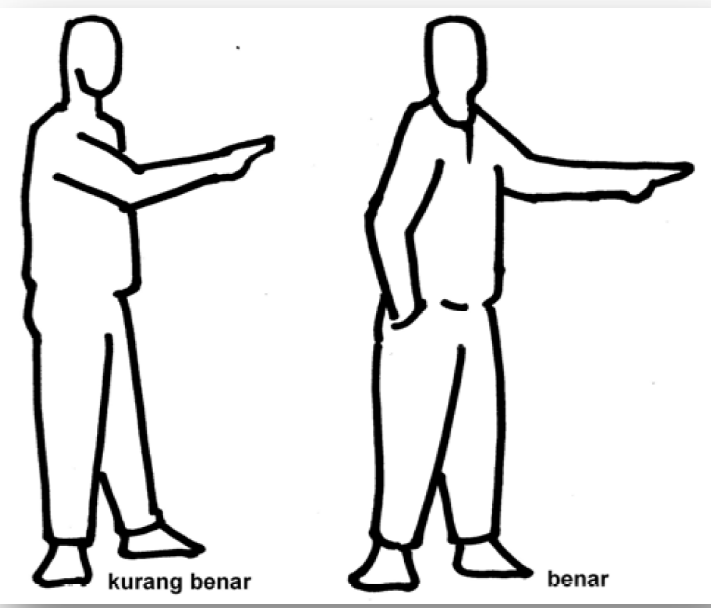

Gambar pose menunjuk

- Gunakan lengan atau tangan panggung atas (yang jauh dari mata penonton) untuk menunjuk ke arah panggung atas dan gunakan lengan atau tangan panggung bawah (yang dekat dengan mata penonton) untuk menunjuk ke panggung bawah. Jika yang dilakukan sebaliknya, maka gerakan lengan dan tangan akan menutupi bagian tubuh lain. Gambar di atas memperlihatkan pemain yang menunjuk dengan lengan panggung atas nampak lebih serasi dan memberi keluasan pandangan. 
- Jangan pernah memegang benda atau piranti tangan di depan wajah ketika sedang berbicara, karena hal ini akan menutupi suara dan pandangan penonton. Gambar di bawah memperlihatkan betapa mengganggunya memegang piranti (telepon) dengan menutupi muka. Jika tangan yang digunakan adalah tangan yang tidak menganggu pandangan penonton, maka gerak laku aktor dalam menggunakan telepon akan kelihatan. Hal ini mempertegas laku aksi yang sedang dikerjakan.

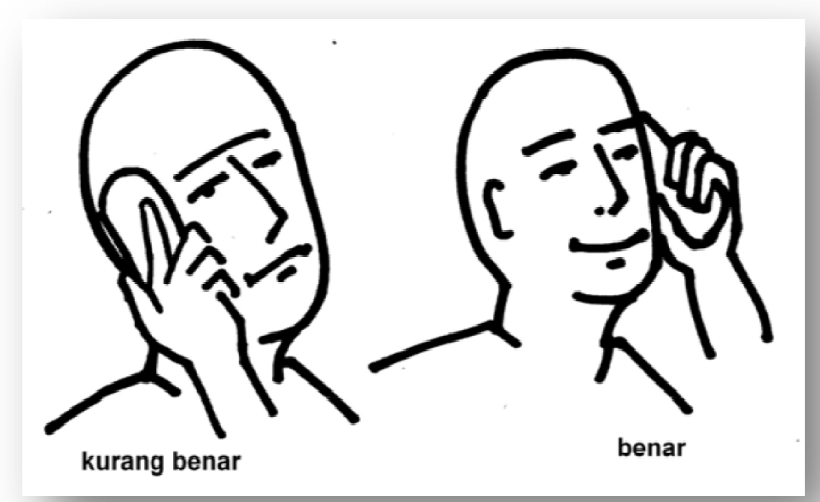

Gambar cara memegang piranti

- Usahakan agar para aktor saling menatap (berkontak mata) pada saat mengawali dan mengakhiri dialog (percakapan). Selebihnya, usahakan untuk berbicara kepada penonton atau kepada aktor lain yang berada di atas panggung. Membagi arah pandangan ini sangat penting untuk menegaskan dan memberi kejelasan ekspresi karakter kepada penonton. Perhatikan gambar aktor yang melakukan kontak mata ketika berbicara di bawah ini.

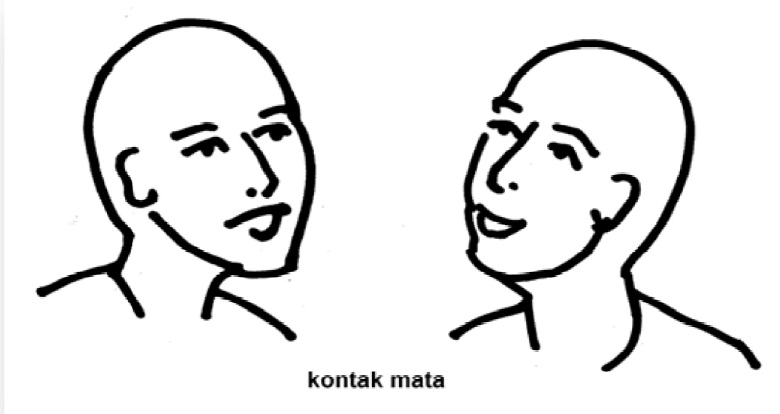

Gambar kontak mata antar aktor 


\section{TEKNIK FOKUS}

Marsh Cassady (1997) menyebutkan beberapa teknik untuk menciptakan fokus pemain di atas panggung, di antaranya dengan memanfaatkan area panggung, memanfaatkan tata panggung, trianggulasi, individu dan kelompok, serta kelompok besar.

\section{PEMANFAATAN AREA PANGGUNG}

Dalam tata panggung, suatu area memiliki kekuatan berbeda dibanding area yang lain. Kekuatan dalam makna blocking di sini adalah, area yang lebih mudah mendapat perhatian mata penonton. Semua area panggung kelihatan sama jika dalam keadaan kosong, tetapi setelah para aktor hadir di dalamnya, maka segera perhatian penonton akan tertuju ke area tertentu yang lebih kuat dibanding area lain. Secara umum, area tengah, area terdekat dengan penonton, serta jarak area, dapat dimanfaatkan untuk menciptakan fokus.

- Area tengah, secara natural lebih kuat jika dibandingkan dengan area di sisi kiri atau kanan. Pemain yang berada di tengah secara otomatis menjadi pusat perhatian penonton sementara pemain yang berada di sisi kanan dan kirinya seolah-olah hadir sebagai penyeimbang. Gambar A di bawah menunjukkan bahwa pemain yang berada di tengah menjadi pusat perhatian. Gambar B di bawah juga menunjukkan hal yang sama, meskipun jumlah pemain di sisi kanan dan kiri lebih banyak tetapi tetap saja pemain yang berada di tengah menjadi pusat perhatian. 


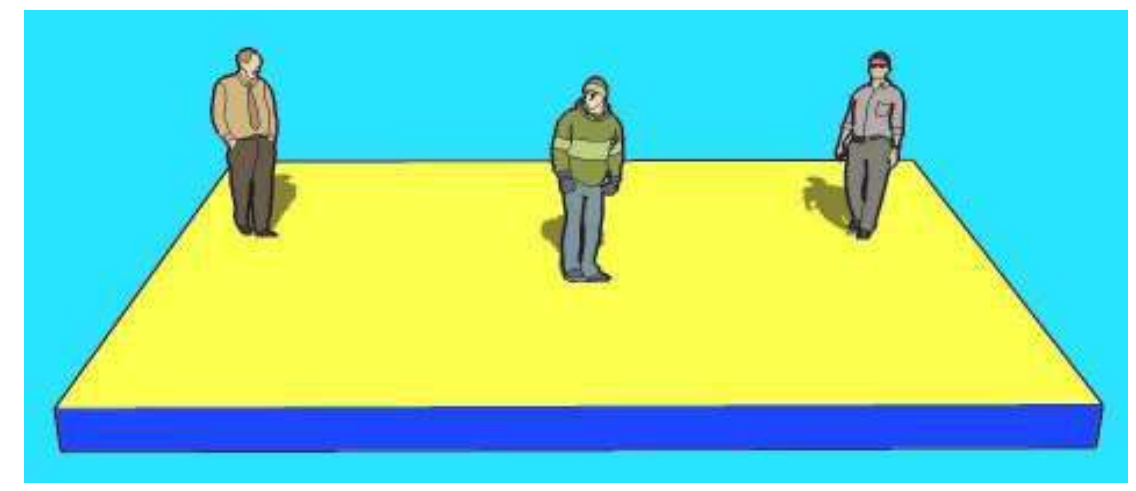

Gambar A Pemain yang berada di tengah menjadi fokus

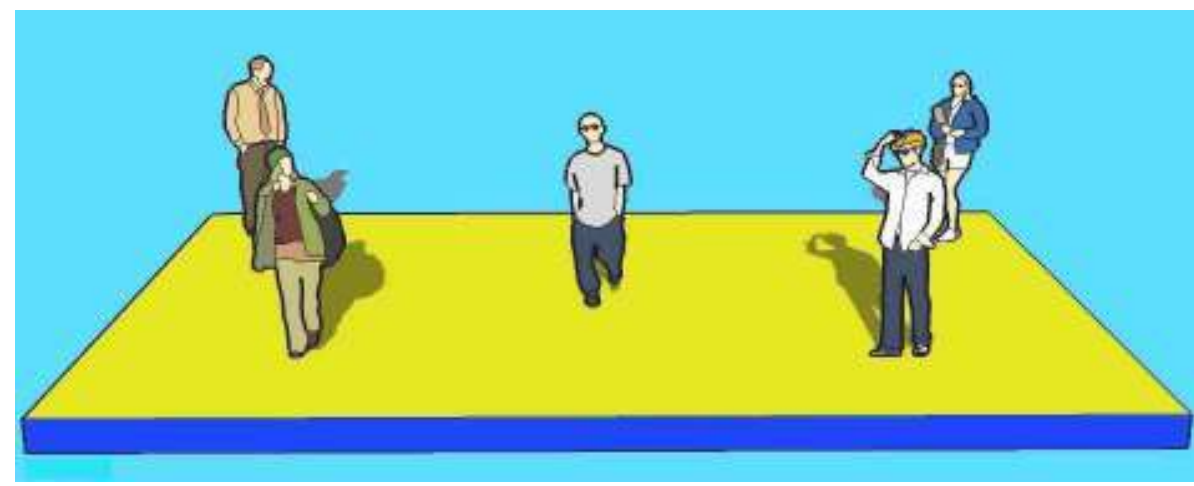

Gambar B Pemain yang berada di tengah tetap menjadi fokus meskipun jumlah pemain di sisi kiri dan kanan lebih banyak

- Area terdekat dengan penonton lebih memiliki kekuatan dibanding dengan area yang jauh dari mata penonton. Gambar di bawah ini memperlihatkan bahwa secara otomatis perhatian penonton akan mengarah pada pemain yang berada lebih dekat daripada yang berdiri di area yang jauh. Mata penonton secara otomatis akan menangkap objek yang lebih dekat dan jelas. Hal ini memberikan jawaban mengapa dalam pertunjukan teater tradisional pemain yang berbicara dan hendak melontarkan pernyataan penting selalu mendekat ke arah penonton. Mereka ingin menjadi pusat perhatian. 


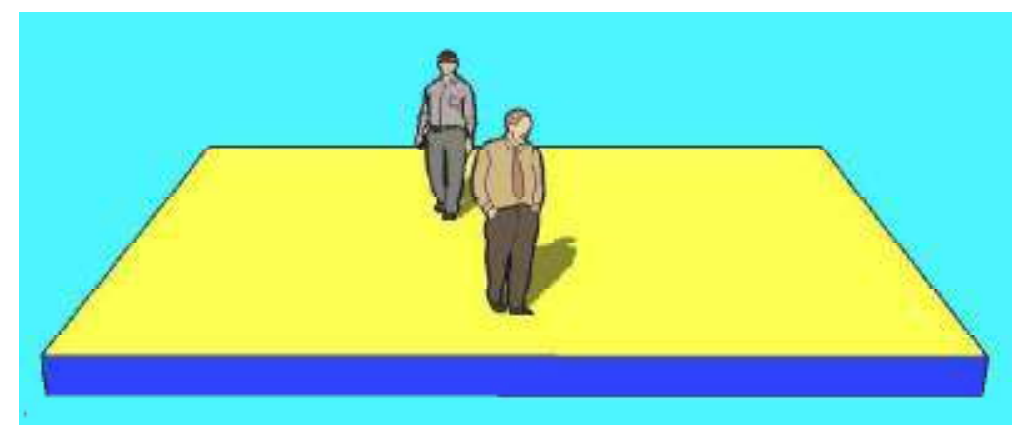

Pemain yang berada lebih dekat dengan penonton menjadi fokus perhatian

- Jarak area satu dengan yang lain jika dimanfaatkan dengan baik dapat menciptakan fokus. Dengan analogi yang lebih terang akan lebih mudah terlihat, maka jarak antararea dapat digunakan untuk memberi penonjolan pada pemain tertentu. Dalam gambar 65 di bawah diperlihatkan bahwa seorang pemain yang menjaga jarak dari sekelompok pemain akan lebih mudah dan enak dilihat.

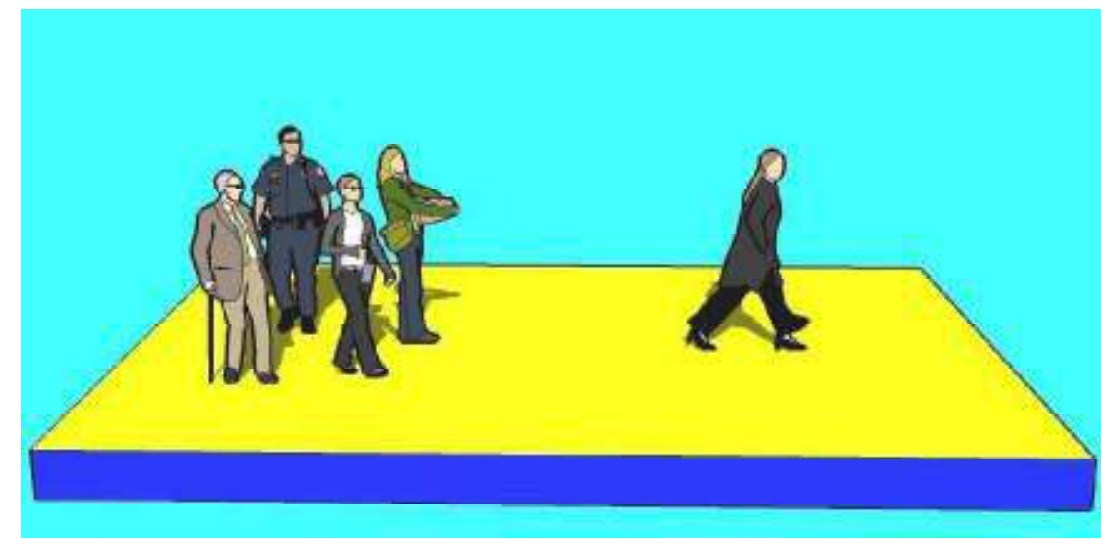

Pemain yang mengambil jarak dari sekelompok pemain akan menjadi fokus

\section{PEMANFAATAN TATA PANGGUNG}

Tata panggung, sesederhana apapun dapat dimanfaatkan untuk menciptakan fokus. Dengan sedikit kejelian, tata dekorasi pentas menghasilkan ruang yang dapat dimaknai secara khusus untuk kepentingan fokus pemain.

- Dengan memanfaatkan posisi tinggi rendah pemain menurut tatanan set dekor yang ada, fokus dapat diciptakan. Posisi pemain yang berdiri di ketinggian biasanya lebih kuat jika dibanding dengan pemain yang ada di 
bawah. Tetapi jika ada dua pemain yang sama tingginya, maka pemain yang berada di bawah justru akan menjadi fokus karena kedudukan tinggi dua pemain akan saling menghapuskan kekuatan satu sama lain.

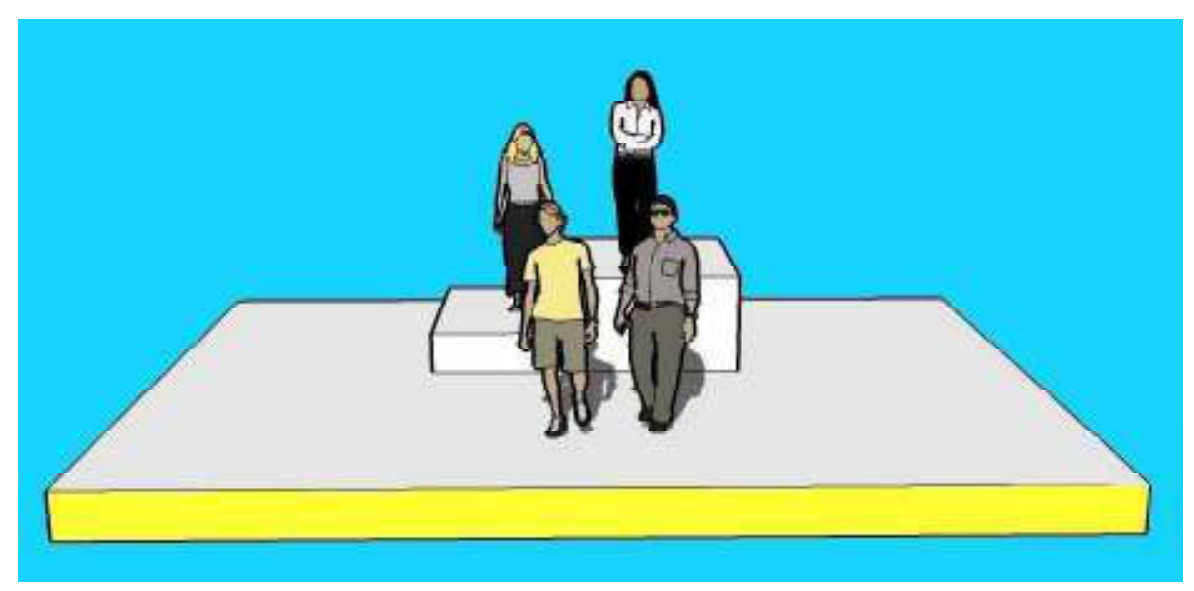

Gambar A. Pemain yang lebih tinggi dari pemain lain menjadi fokus

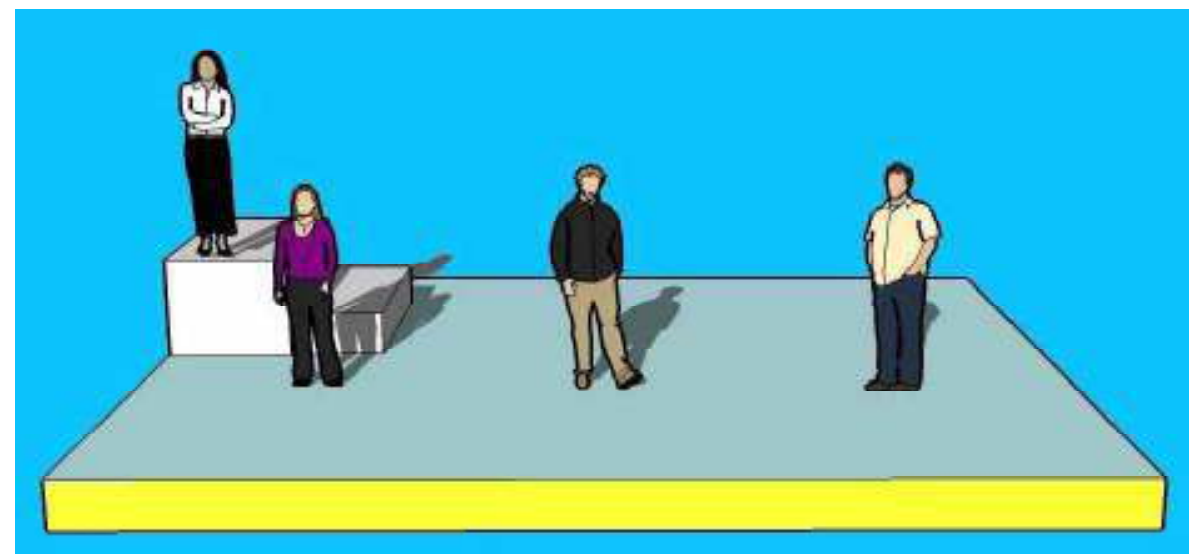

Gambar B

Pemain yang berada pada level tinggi tetap menjadi fokus meskipun pemain lain mengambil jarak 


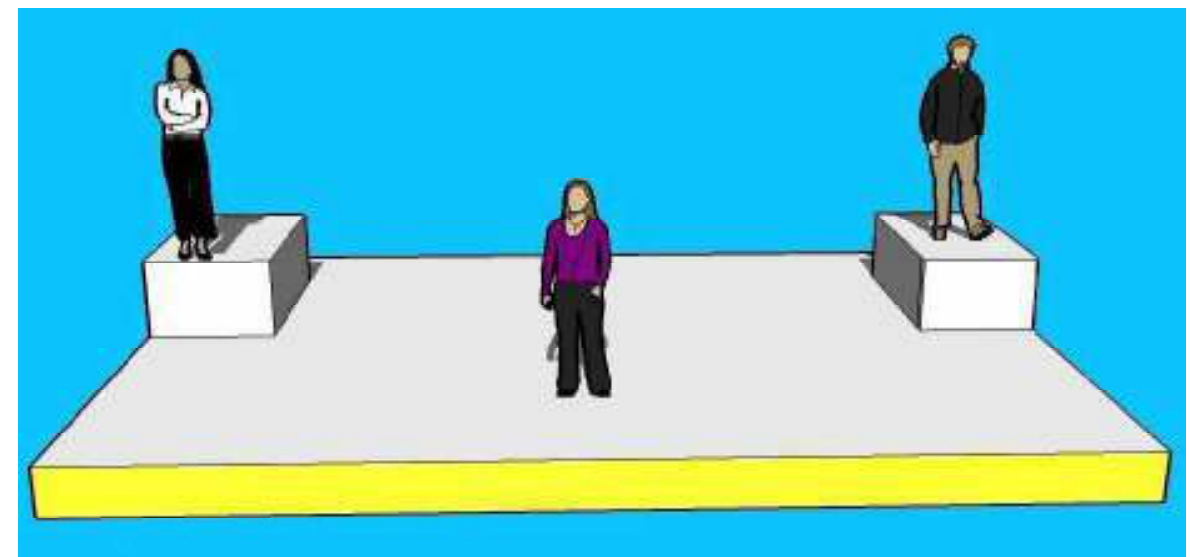

Gambar C. Pemain yang berdiri di tengah menjadi fokus

Dalam gambar A di atas pemain yang berdiri paling tinggi di antara sekumpulan pemain mencuri perhatian dan menjadi fokus. Meskipun posisi pemain disebar tetap saja pemain yang berdiri paling tinggi menjadi pusat perhatian (Gb.B). Sementara dalam gambar $\mathrm{C}$, pemain yang berdiri paling rendah justru menjadi pusat perhatian karena pemain yang berdiri tinggi di kanan dan kiri justru saling menghapuskan fokus.

- Tata dekorasi pentas sering menggunakan bingkai dalam wujud jendela, pintu atau bingkai yang lain. Selain sebagai penguat artistik pementasan, bingkai dapat dimanfaatkan untuk menciptakan fokus

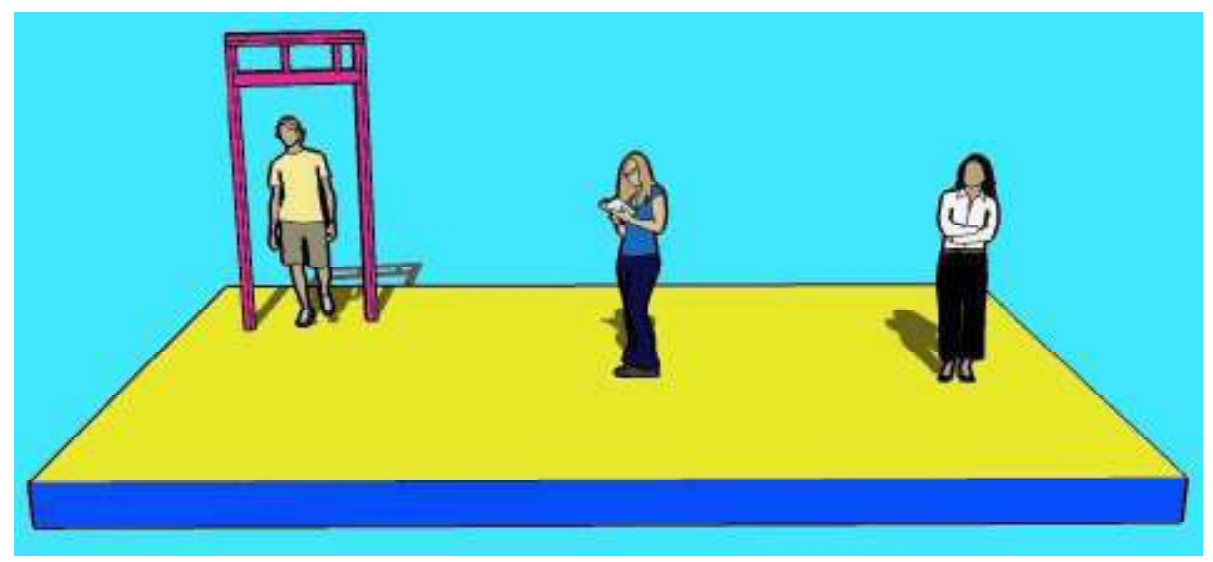

Gambar A Fokus dengan memanfaatkan bingkai 


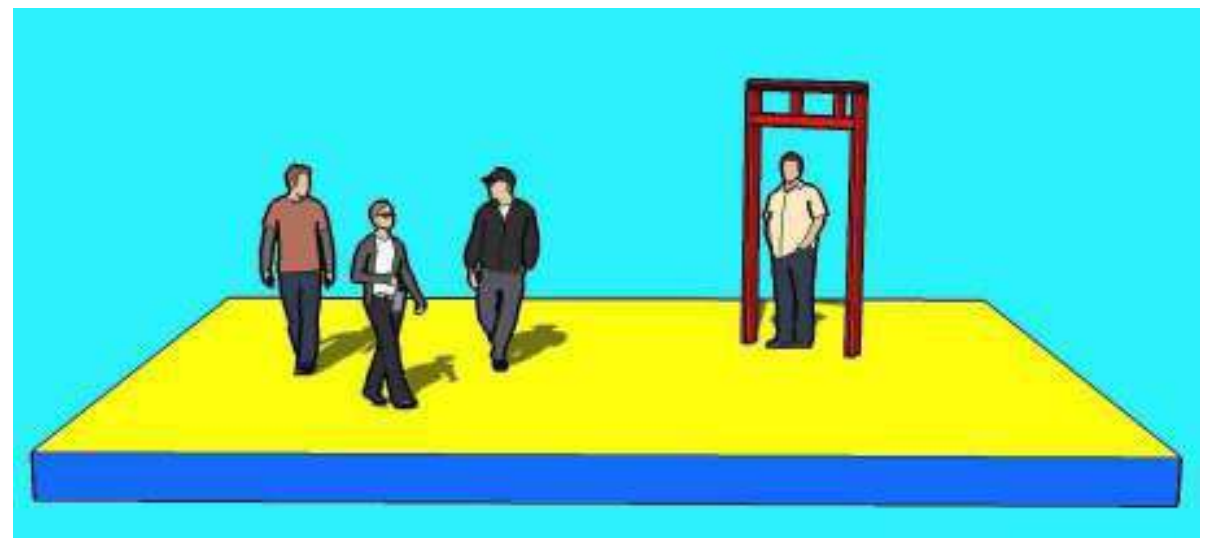

Gambar B Pemain yang berada di tengah bingkai menjadi fokus

Pemain yang berada di dalam bingkai lebih memiliki kekuatan dibanding dengan yang berada di luar bingkai. Dalam dua gambar di atas (Gb.A dan Gb.B) diperlihatkan bahwa posisi pemain yang beradar di dalam bingkai lebih menarik perhatian dibanding yang lainnya.

\section{TRIANGGULASI}

Untuk menciptakan fokus yang mudah dan natural adalah menempatkan pemain dalam posisi segitiga. Setiap pemain akan mudah terlihat oleh penonton dan mereka dapat melihat satu sama lain sehingga perubahan gerak dan karakter akan lebih cepat ditangkap. Selain itu posisi segitiga memudahkan perpindahan pemain dari titik satu ke titik yang lain tanpa menghilangkan fokus. Penempatan pemain dengan berdasar pada bentuk segitiga ini disebut trianggulasi. Banyak kreasi segitiga yang bisa diwujudkan baik dengan jumlah pemain sedikit ataupun banyak. Gambar di bawah ini (Gb.A, B dan C) memperlihatkan variasi fokus trianggulasi dengan jumlah pemain minimal 3 orang. 


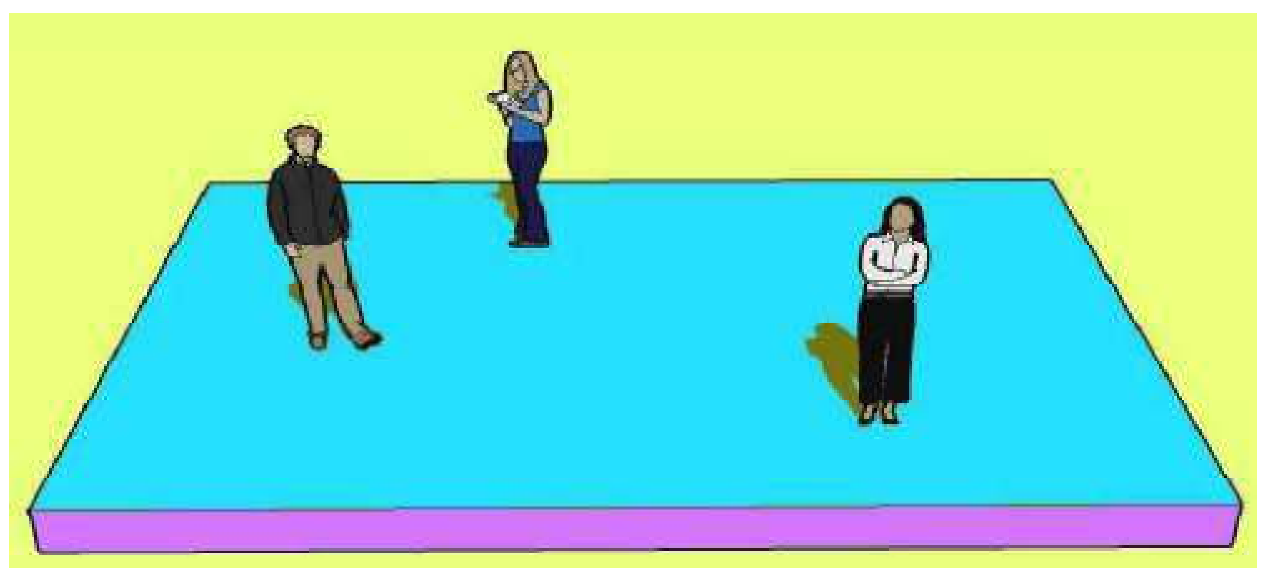

Gambar A Variasi trianggulasi 1

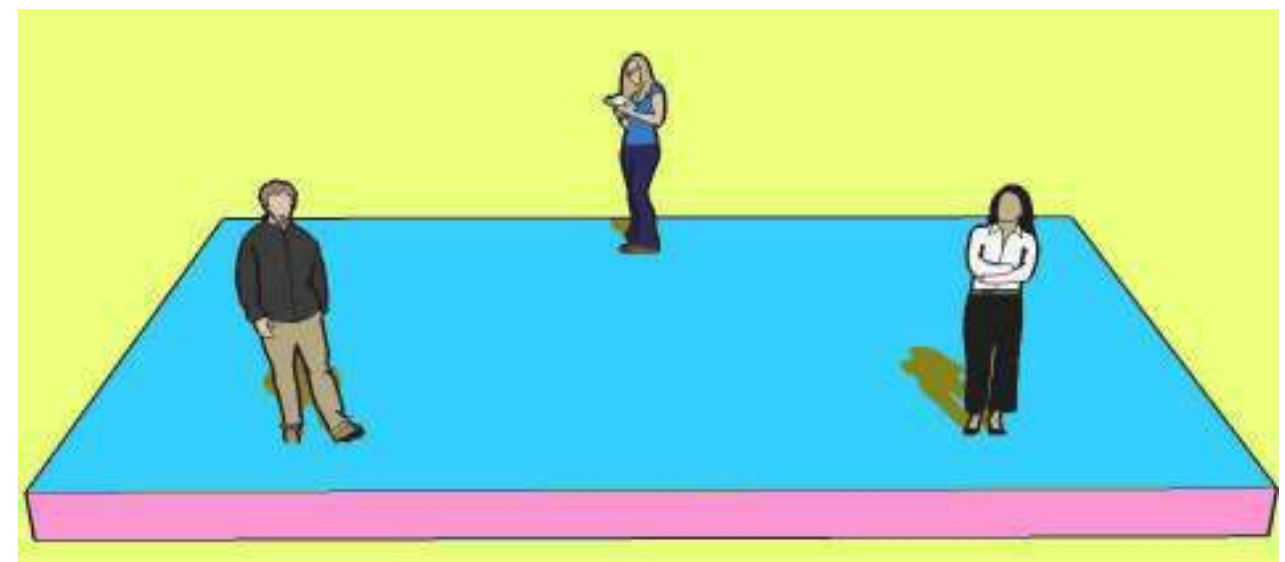

Gambar B Variasi trianggulasi 2

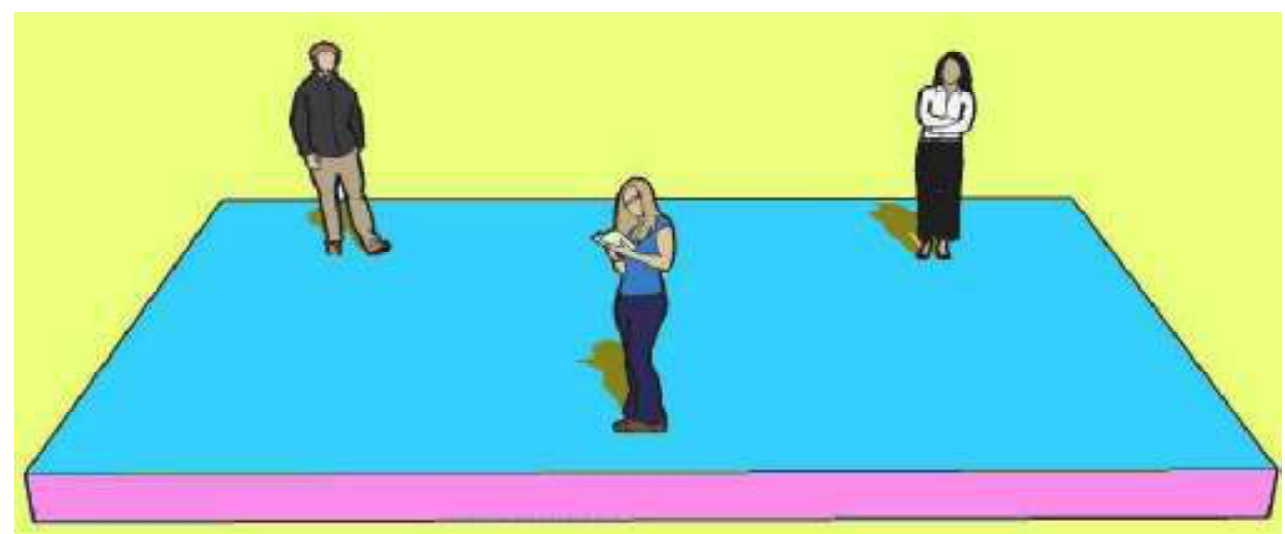

Gambar C Variasi trianggulasi 3 
Dari gambar di atas dapat diketahui bahwa pergeseran posisi satu pemain dan pemain yang lain menghasilkan bocking yang tidak saling menutupi. Semua dapat ditangkap dengan jelas oleh penonton. Pada posisi ini fokus bisa bergantiganti tergantung dari arah gerak dan laku aksi yang diperagakan oleh pemain di atas pentas.

\section{INDIVIDU DAN KELOMPOK}

Fokus juga dapat diciptakan dengan memisahkan satu orang pemain dari sekelompok pemain yang ada. Penonton akan lebih tertarik untuk melihat satu orang daripada sejumlah orang dalam sebuah kelompok yang biasanya memiliki gestur, pose, dan aktivitas yang sama. Gambar A dan B di bawah memperlihatkan penataan individu yang berjarak dengan kelompok.

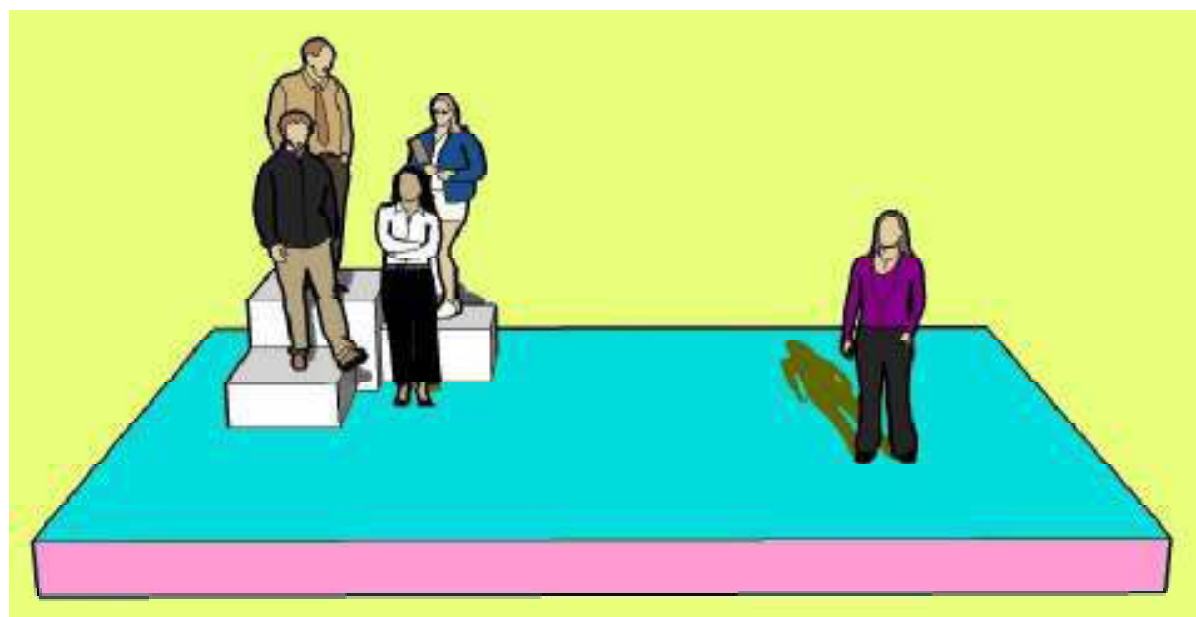

Gambar A Fokus Individu dari kelompok 1

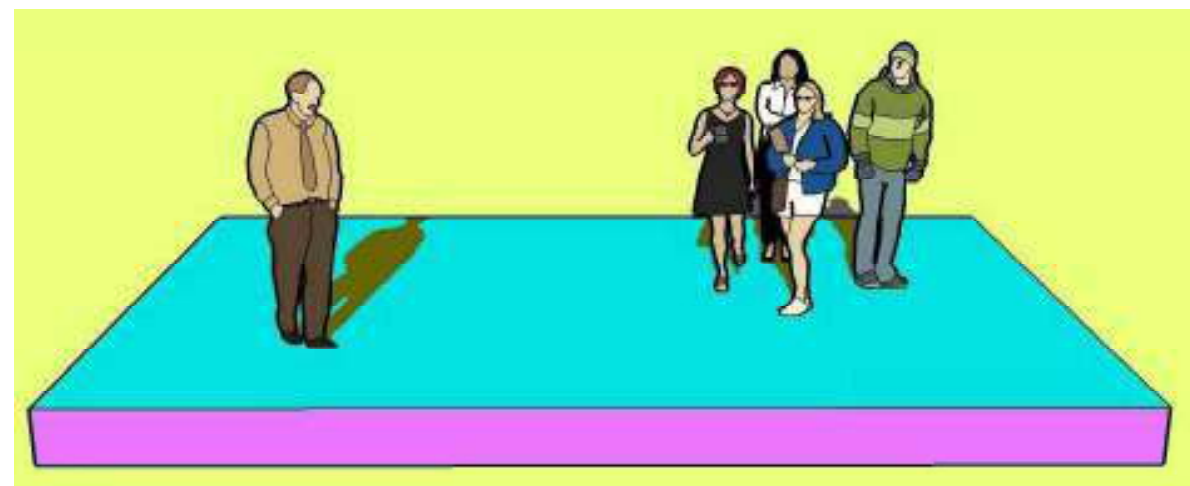

Gambar B Fokus individu dari kelompok 2 


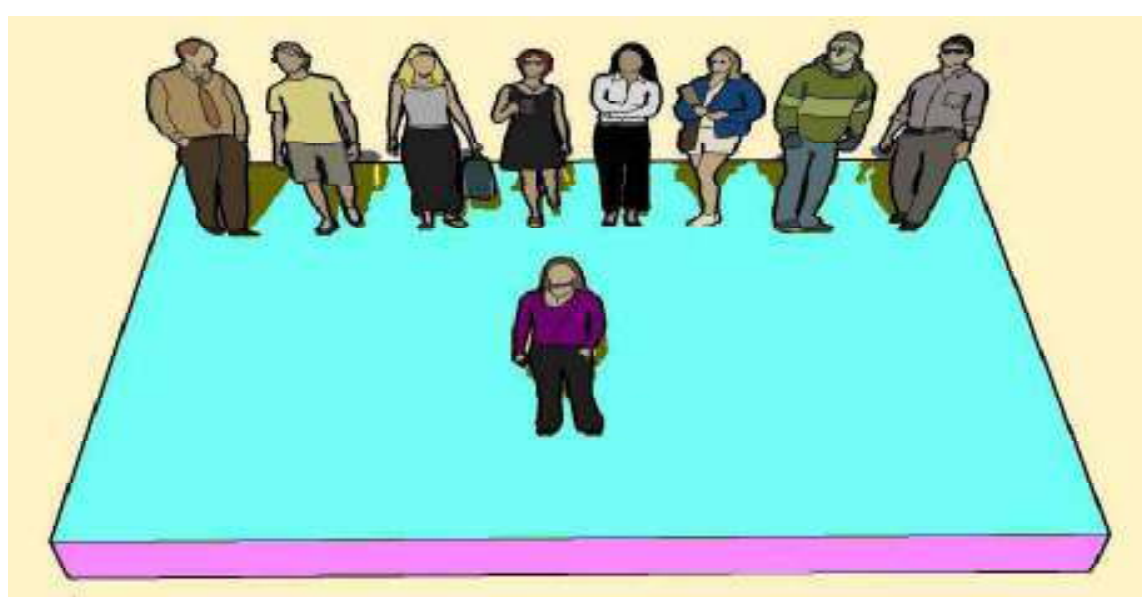

Gambar C Fokus individu dari kelompok yang membentuk komposisi garis lurus

Gambar C di atas memperlihatkan pemisahan individu dan kelompok, dimana kelompok membentuk garis lurus. Sedangkan dalam gambar D di bawah kelompok membentuk setengah lingkaran sehingga energi dan perhatian yang diberikan kepada individu menjadi lebih besar.

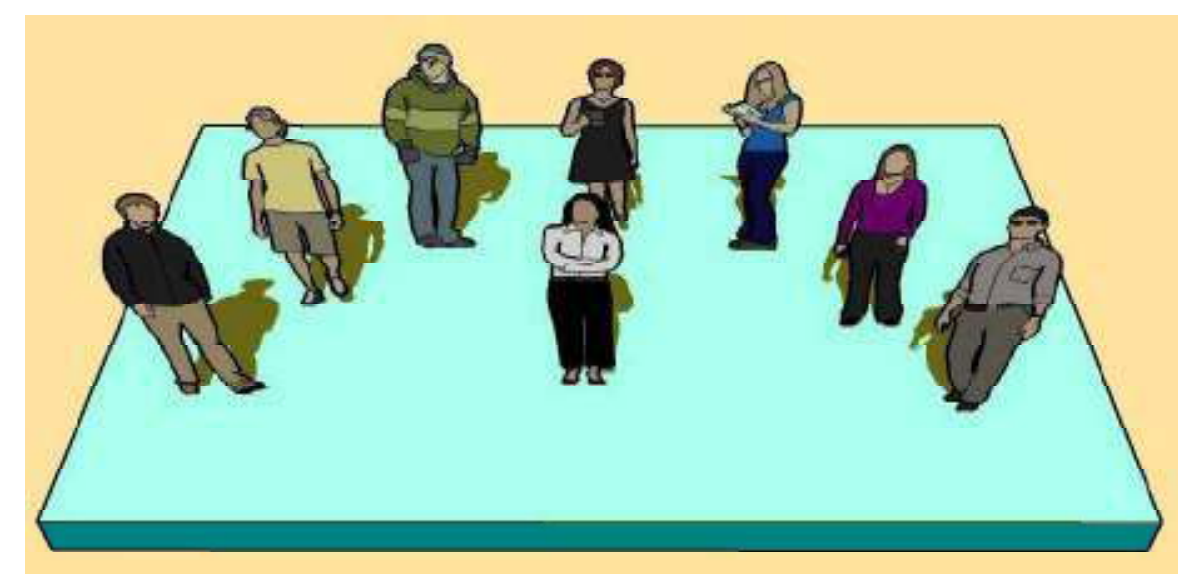

Gambar D Fokus individu dari kelompok yang membentuk komposisi setengah lingkaran

Seorang pemain yang posisinya berbeda dari sekelompok pemain secara otomatis akan lebih menarik perhatian penonton. Seseorang yang jongkok di antara beberapa orang yang berdiri pasti memliki daya tarik yang lebih kuat untuk dilihat, demikian juga sebaliknya. 


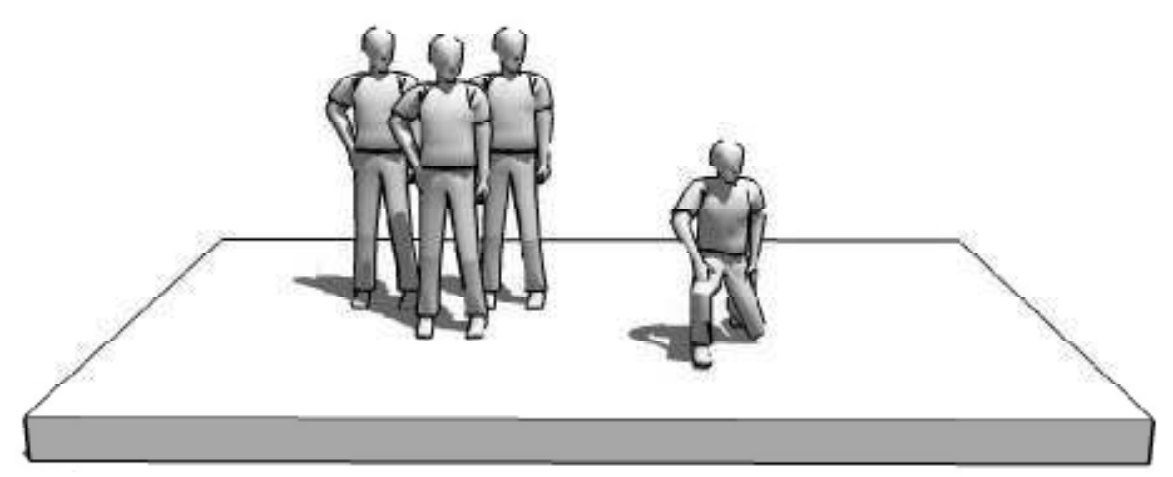

Gambar E Fokus dengan membedakan pose dan level pemain 1

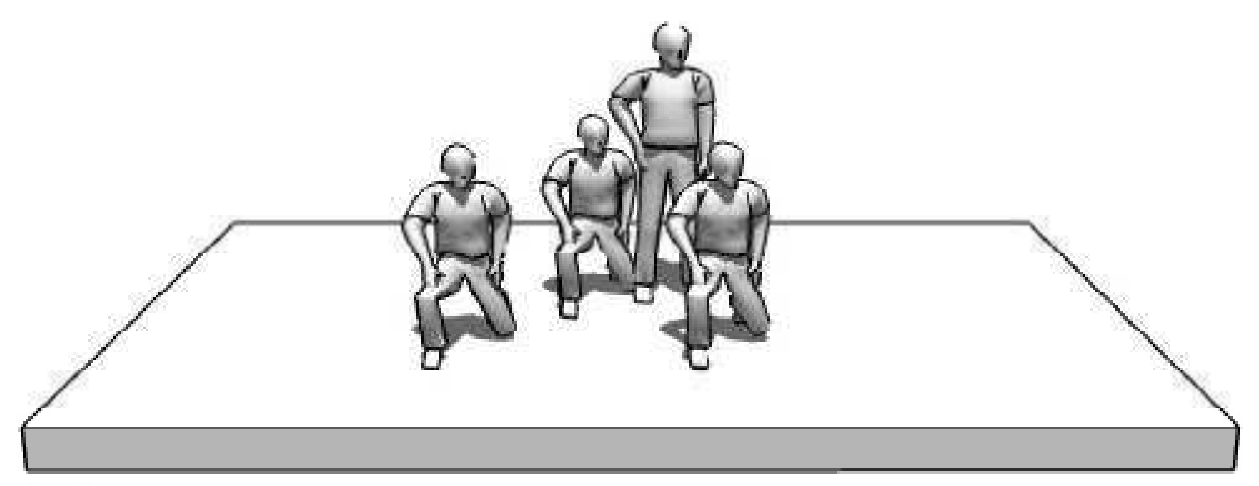

Gambar F Fokus dengan membedakan pose dan level pemain 2

Gambar $\mathrm{E}$ dan $\mathrm{F}$ di atas memperlihatkan bahwa perhatian penonton akan terarah pada pemaian yang berbeda di antara yang lain. Pembedaan pose dan level ini tentu saja harus diikuti pembedaan laku aksi dalam lakon. Misalnya, pemain yang mengambil pose berbeda adalah pimpinan kelompok sehingga ia memiliki peran yang lebih besar daripada yang lainnya.

\section{KELOMPOK BESAR}

Menempatkan pemain dalam kelompok besar membutuhkan teknik tersendiri karena dalam sebuah blocking kelompok tidak ada individu yang lebih menonjol dari yang lain. Artinya, fokus atau perhatian penonton ditujukan kepada sekelompok pemain. Untuk itu ada empat teknik dasar yang bisa diterapkan, yaitu garis, lingkaran, setengah lingkaran, dan segitiga. 


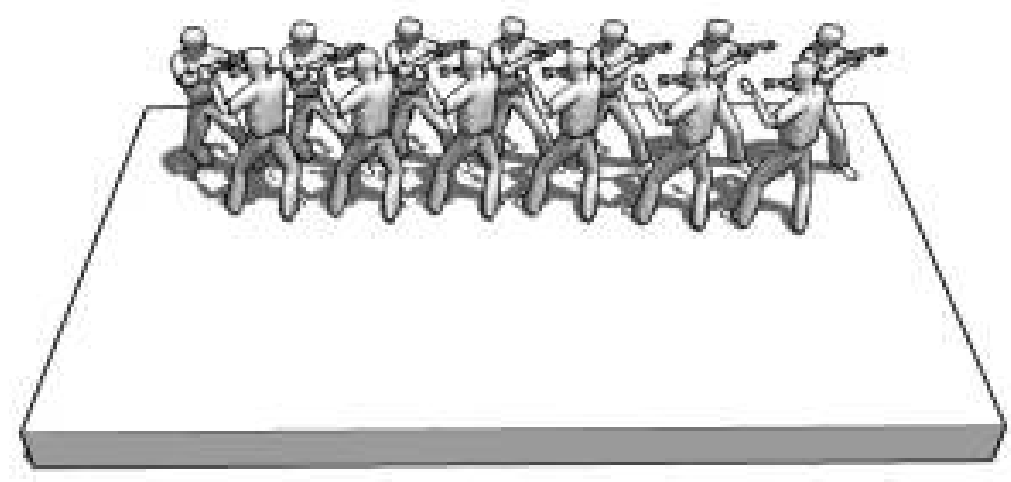

Teknik garis

Penempatan pemain dengan teknik garis seperti gambar di atas menguntungkan pemain, karena semua berada dalam posisi sejajar sehingga tidak ada pemain yang lebih mononjol. Teknik ini dapat diterapkan dengan membentuk satu atau lebih dari satu garis dengan kombinasi tinggi rendah pemain. Dalam adegan chorus atau paduan suara, penempatan kelompok dengan teknik garis sering digunakan.

Penempatan pemain dengan teknik lingkaran seperti gambar di bawah (lingkaran 1) sangat tidak menguntungkan karena sebagin pemain yang berdiri di belakang tidak dapat dilihat oleh penonton. Meski demikian, teknik ini seringkali digunakan dengan mengkombinasikan gerak kelompok. Artinya, jika semua pemain dalam keadaan diam dalam waktu yang lama, teknik lingkaran kurang menguntungkan tetapi jika semua pemain bergerak bersama sehingga posisi antarpemain saling berpindah maka teknik ini memiliki kekuatan fokus yang besar.

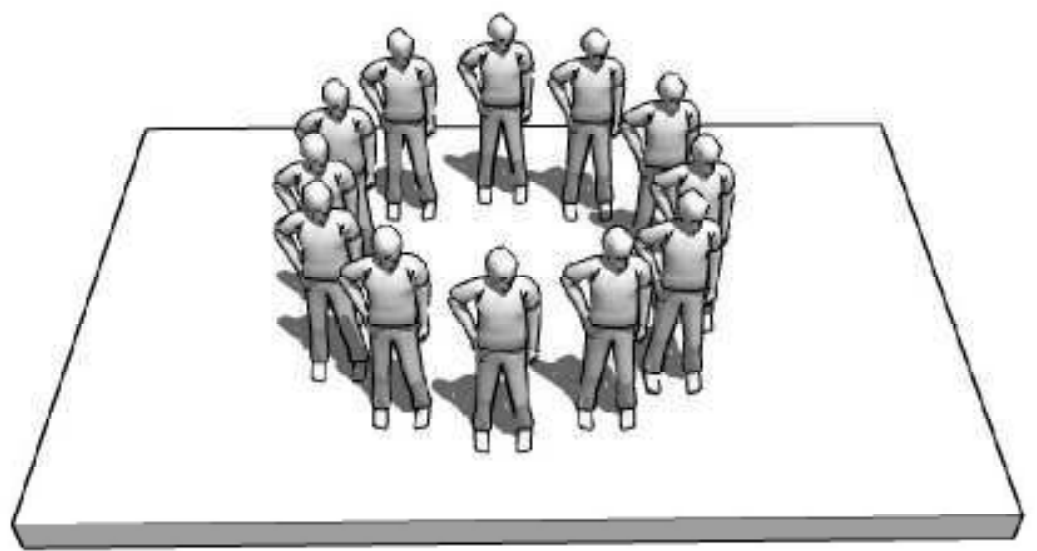

Teknik lingkaran 1 


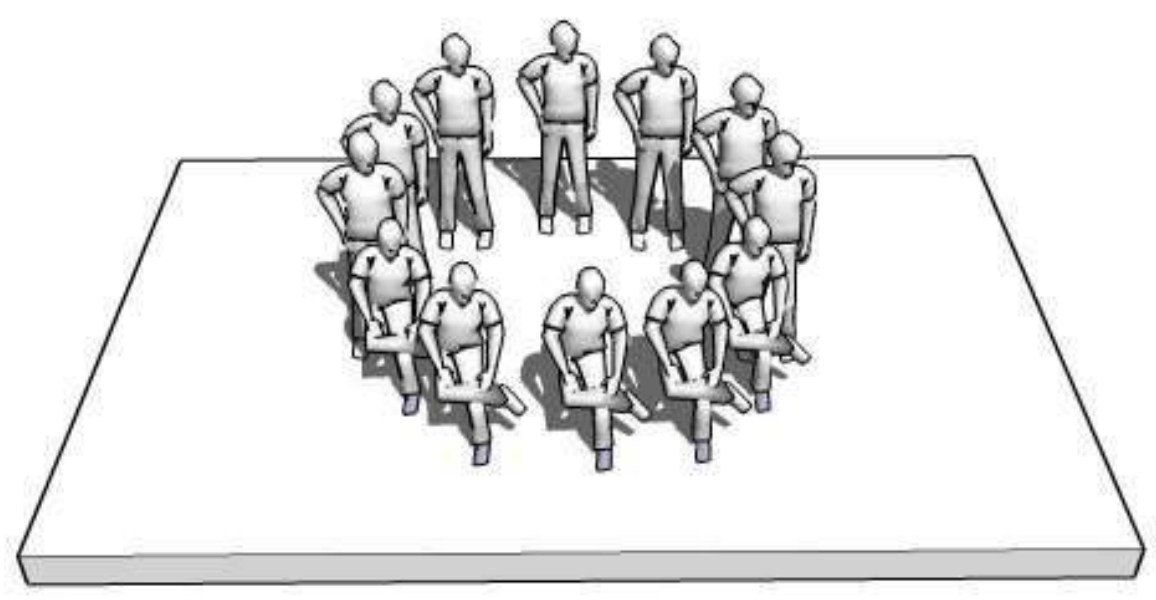

Teknik lingkaran 2

Dalam bentuk lingkaran posisi pemain dapat dimodifikasi seperti gambar Teknik lingkaran 2. Pemain yang berada di depan mengambil posisi lebih rendah dari pemain yang ada di belakang sehingga semua pemain dapat terlihat. Hal ini menguntungkan karena posisi pemain dapat bertahan lama meskipun dalam kondisi statis.

Bentuk setengah lingkaran, memliki keuntungan seperti teknik garis (Gb di bawah). Semua pemain terlihat. Tetapi bentuk ini secara dimensional lebih menguntungkan tetapi untuk uang pentas yang kecil kurang menguntungkan. Bentuk setengah lingkaran membutuhkan tempat yang lebih luas untuk memberi ruang kosong di tengah. Posisi ini sering juga digunakan untuk chorus.

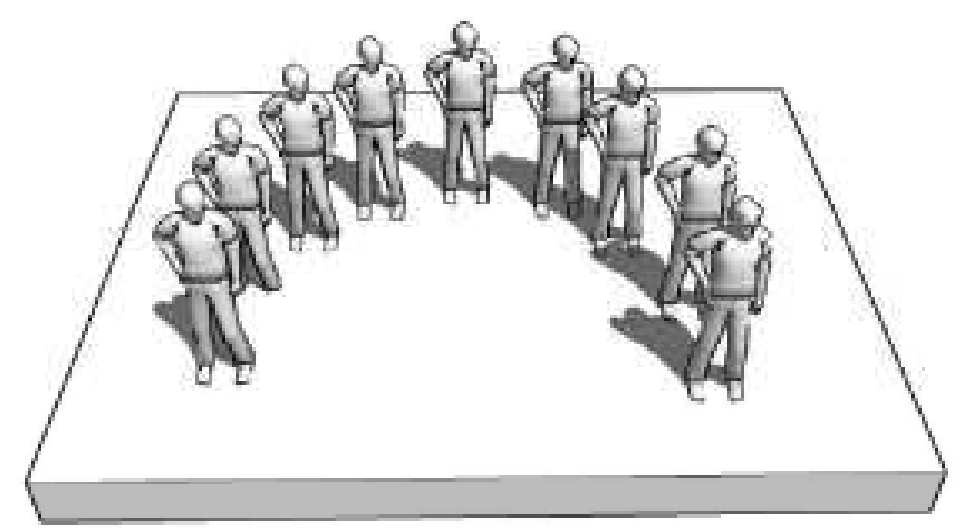

Teknik setengah lingkaran 
Penempatan kelompok pemain dengan teknik segitiga lebih memiliki kemungkinan kreativitas. Dengan mengkombinasikan bentuk segitiga masingmasing kelompok pemain dapat ditempatkan secara proporsional sehingga tidak saling menutupi. Seperti dalam gambar di bawah, semua pemain dapat dilihat oleh penonton sehingga penonjolan pemain sangat tergantung dari aksi dan aktifitas peran yang dimainkan.

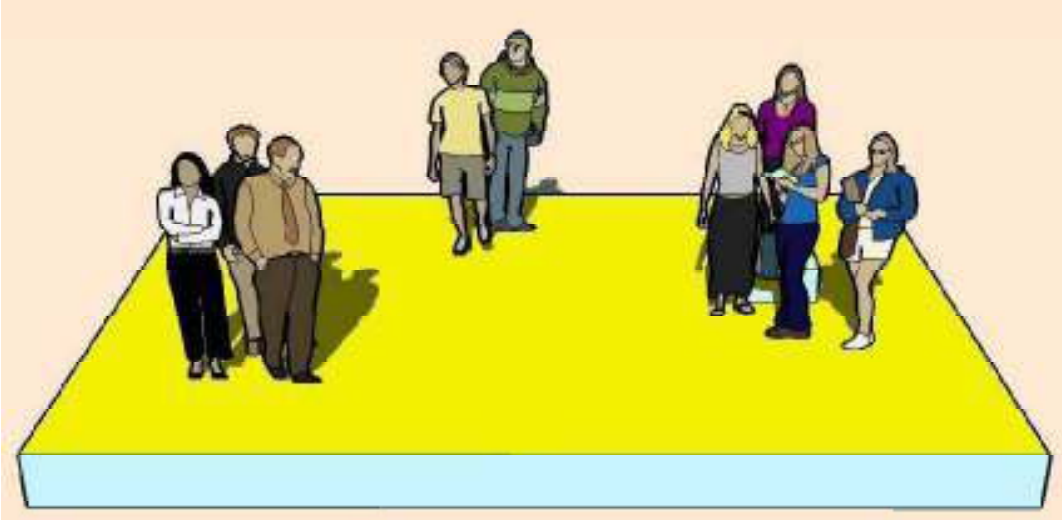

Teknik segitiga

MOBILITAS PEMAIN

Selain mengatur dan menempatkan posisi pemain di atas pentas, blocking juga mengatur mobilitas atau perpindahan pemain dari titik satu ke titik yang lain. Jika perpindahan para pemain tidak diatur dengan baik maka lalulintas pemain akan menjadi semrawut sehingga fokus pertunjukan menjadi kabur yang akibatnya makna lakon tidak sampai.

Untuk menghindari hal tersebut perlu diatur mobilitas pemain dengan pertimbangan peristiwa, fokus, dinamika lakon, dan pengaturan arah gerak.

- Peristiwa memberikan gambaran watak kejadian yang ada di atas panggung. Watak kejadian ini bisa digunakan sebagai acuan untuk mengatur mobilitas pemain. Misalnya, dalam peristiwa duka, perpindahan pemain dari titik satu ke titik dilakukan dengan tenang. Pergerakan antarpemain dibatasi. 
Sebaliknya dalam peristiwa kekacauan, perpindahan para pemain dapat dilangsungkan dengan cepat.

- Fokus yang telah ditetapkan pada pemain tertentu dalam situasi tertentu harus didukung oleh mobilitas pemain lainnya. Artinya, gerak, posisi, dan ekspresi pemain lain harus menguatkan gerak, posisi, dan ekspresi pemain yang menjadi fokus. Jika intensitas gerak semua pemain sama, maka fokus tidak akan tercipta dan makna adegan yang dimaksudkan melalui laku aksi pemain yang menjadi fokus menjadi kabur. Hal ini mempengaruhi dinamika lakon secara keseluruhan.

- Dinamika lakon mempengaruhi pergerakan pemain di atas pentas. Perubahan situasi dalam jalinan peristiwa lakon harus dibarengi dengan perubahan laku aksi setiap pemain yang terlibat di dalamnya. Oleh karena itu, mobilitas pemain perlu diatur dan disesuaikan dengan dinamika laku lakon di atas pentas.

- Pengaturan arah gerak ditetapkan untuk mengatur pergerakan dan perpindahan pemain secara teknis. Dengan mengatur arah gerak setiap pemain, laku aksi menjadi kelihatan kaku dan mekanis tetapi perpindahan pemain menjadi teratur sehingga setiap laku aksi dapat ditangkap oleh mata penonton.

Pengaturan mobilitas pemain seperti tersebut di atas merupakan hal penting yang harus dipahami oleh sutradara. Tidak ada artinya seorang pemain bermain dengan sangat baik jika pola gerak dan perpindahan pemain lain tidak mendukung. Dalam teater, semua pemain, semua peran memegang kedudukan yang sama karena saling mendukung untuk menciptakan harmoni lakon. Oleh karena itu, mobilitas semua pemain yang terlibat dalam pertunjukan harus diatur dengan baik sehingga makna lakon yang hendak disampaikan dapat diterima dengan baik oleh penonton dan pertunjukan berjalan menarik. 


\section{BAB III}

\section{OLAH TUBUH}

DESKRIPSI

Materi olah tubuh berisi penjelasan praktikal untuk melatih tubuh aktor oratoris. Latihan tubuh bertujuan agar aktor oratoris memiliki kelenturan tubuh yang baik sehingga dapat mendukung gerak tubuhnya selama memainkan perannya di depan publik audien.

\section{MANFAAT}

Dengan memahami materi praktikal ini mahasiswa dapat melaksanakan praktik latihan olah tubuh dengan baik dan dengan arahan yang jelas.

\section{TUJUAN INSTRUKSIONAL KHUSUS}

Setelah memahami materi ini, mahasiswa dapat 1) memahami tata kegiatan olah tubuh yang baik, 2) melaksanakan kegiatan olah tubuh, dan 3) menyusun dan mengembangkan langkah kegiatan olah tubuh.

\section{OLAH TUBUH}

Pemeran atau aktor adalah salah satu elemen pokok dalam pertunjukan teater. Sebelum memainkan karakter, pemeran harus menguasai tubunhya. Oleh karena itu, seorang pemeran harus ikhlas belajar demi pencapaian kualitas tubuh agar enak ditonton. Proses belajar penguasaan tubuh memerlukan waktu yang panjang dan secara kontinu serta tidak bisa dilakukan secara terburu-buru. Pemeran harus bersabar dan tidak boleh ada rasa jenuh dalam melakasanakannya. 
Penampilan fisik pemeran dalam pentas berhubungan dengan penampilan watak, sikap, gesture, dan umur peran yang digambarkan. Hal ini juga sangat berhubungan dengan penampilan laku fisik yang digariskan pengarang, sutradara, dan tuntutan peran. Tampilan fisik seorang pemeran adalah tanggungjawab pribadi pemeran.

Seorang pemeran adalah seorang seniman yang memainkan peran yang digariskan oleh penulis naskah dan sutradara. Untuk mewujudkan laku peran di atas pentas, pemeran harus mengetahui, memahami, dan memfungsikan dengan baik alat dan sarana yang akan dipergunakan. Alat dan sarana tersebut adalah tubuh dan jiwanya sendiri.Tidak ubahnya seorang pelukis yang memahami fungsi dan manfaat dari kuas, palet, pensil, cat, kanvas, dan figura. Begitu juga dengan seorang pemeran, dia harus tahu betul cara berjalan yang gagah, jalannya orang yang sudah sangat tua, cara membungkuk, cara menengok, cara melambai, bagaimana posisi punggungnya, dan lain-lain. Oleh karena tubuh pemeran sangat dominan di atas pentas, maka penguasaan tubuh menjadi kewajiban.

Tubuh manusia terdiri dari tulang, urat, dan otot-otot sebagai penghubungnya. Tulang manusia terdiri dari ratusan jenis, mulai tulang tengkorak, tulang leher, tulang badan, tulang tangan, tulang pinggul, dan tulang kaki. Bagian yang paling penting dari tubuh manusia adalah tulang belakang atau tulang punggung. Tulang punggung terdiri dari dua puluh empat buah ruas asli dan sembilan buah ruas palsu (semu).

Ruas asli dipisahkan satu dengan yang lain melalui tulang rawan (cartilago) yang berbentuk piringan dan berfungsi untuk memudahkan gerakan tulang satu dengan yang lain. Sedangkan 9 buah ruas palsu menyatu dalam satu kesatuan sehingga tidak memungkinkan untuk menimbulkan gerak. Tulang punggung juga berfungsi sebagai tangkai dari jalinan urat saraf. Pusat saraf terdiri dari otak dan jaringan urat saraf tulang belakang. Tulang yang berhubungan langsung dengan tulang belakang adalah tulang belikat (Scapula), dan tulang pinggul (Coxae). Cara berbaring, duduk, berdiri, berjalan, berlari, melompat, dan jatuh sangat dipengaruhi oleh tulang belakang. Elastisitas atau kelenturan tulang belakang berfungsi sebagai peredam goncangan atau shock breaker tubuh.

Dalam pemeranan, posisi tulang belakang dapat menyampaikan pesan atau gambaran pada penonton berbagai kondisi yang dialami. Gambaran ketika sedang 
tegang atau tenang, letih atau segar, tua atau muda sangat dipengaruhi oleh posisi tulang belakang. Tulang belakang juga membantu keberlangsungan perubahan sikap tubuh dan bunyi suara. Secara anatomis bagian-bagian tulang terdiri dari beberapa bagian, yaitu:

- Kelompok tulang kepala atau tengkorak (cranium).

- Tujuh buah ruas tulang tengkuk atau leher (vertebra cervicalis).

- Dua belas buah ruas tulang belakang atau punggung (vertebra horacalis).

- Lima buah ruas tulang pinggang (vertebra lubalis).

- Lima buah ruas yang bersatu tulang kelangkang (os sacrum).

- Empat buah ruas yang bersatu tulang ekor (os coccygis).

- Kelompok tulang tangan(extremitas superior).

- Kelompok tulang kaki (extremitas inferior).

- Kelompok tulang dada.

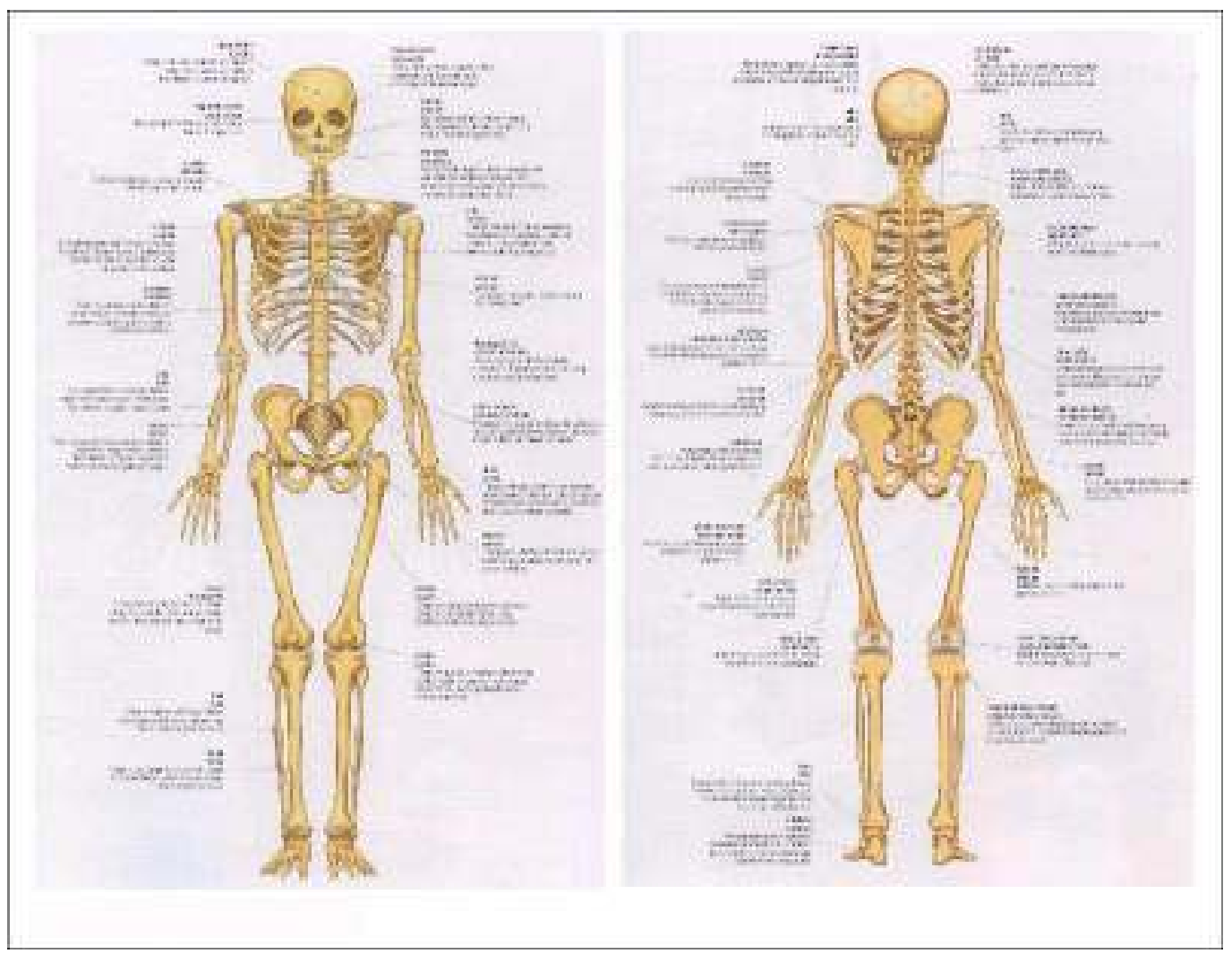

Gambar tulang rangka manusia

Rangkaian yang dihubungkan dengan tulang belakang adalah pengikat bahu (gelang bahu) yang terdiri dari dua buah tulang selangka dan dua buah tulang belikat (bagian atas), rongga dada, dan gelang panggul atau biasa disebut pinggul (bagian bawah). Tulang punggung atau tulang belakang sangat mempengaruhi 
pembentukan seluruh tubuh. Apabila tulang punggung ditegangkan, maka koordinasi dan aliran gerak tubuh terhalang (terganggu).

Gerak tubuh manusia juga dipengaruhi sendi-sendi tubuh yang ada. Sendi adalah hubungan yang terbentuk antara dua tulang. Sendi dapat dikelompokkan menjadi tiga bagian, yaitu sendi fibrus, sendi tulang rawan, dan sendi sinovil. Sendi fibrus adalah sendi yang tidak dapat bergerak, maka tidak mungkin terjadi pergerakan antara tulangtulangnya. Contoh sendi ini adalah sendi tulang pipih tengkorak.

Sendi tulang rawan yaitu sendi dengan sedikit gerakan dan persendiannya dipisahkan oleh tulang rawan. Contoh sendi ini adalah sendi yang terdapat pada simfilis dan pubis, untuk mempersatukan tulang pubis. Sedangkan sendi sinovil atau diartroses adalah sendi yang dapat bergerak bebas.

Sendi sinovil dibagi menjadi enam jenis, yaitu sendi datar, sendi putar, sendi engsel, sendi condiloid, sendi poros, dan sendi pelana. Sendi datar atau geser adalah sendi yang memiliki dua permukaan datar dari tulang dan saling meluncur antara satu tulang dengan yang lain. Contoh sendi sinovil adalah sendi carpus dan sendi tarsus. Sendi putar, yaitu sendi yang memiliki ujung bulat tepat masuk ke dalam rongga cawan atau mangkuk tulang lainnya yang dapat bergerak ke segala jurusan. Contoh sendi bahu, sendi pinggul. Sendi engsel yaitu sendi yang memiliki satu permukaan yang diterima oleh tulang lainnya sedemikian rupa sehingga hanya memberi kemungkinan gerakan dalam satu bidang saja. Contoh sendi siku. Sendi Condiloid yaitu sendi yang mirip dengan sendi engsel tetapi dapat bergerak dalam dua bidang, ke belakang dan ke depan, ke samping dan ke tengah tetapi tidak rotasi. Contoh sendi pergelangan tangan. Sendi poros atau putar yaitu sendi yang hanya mungkin melakukan putaran seperti pada gerakan kepala. Sendi Pelana yaitu sendi yang timbal balik menerima. Contoh antara trapezium dan tulang metacarpal pertama dari ibu jari yang memberi kebebasan bergerak.

Latihan olah tubuh melatih kesadaran tubuh dan cara mendayagunakan tubuh. Olah tubuh dilakukan dalam tiga tahap, yaitu latihan pemanasan, latihan inti, dan latihan pendinginan. Latihan pemanasan (warm-up), yaitu serial latihan gerakan tubuh untuk meningkatkan sirkulasi dan meregangkan otot dengan cara bertahap. Latihan inti, yaitu serial pokok dari inti gerakan yang akan dilatihkan. 
Latihan pendinginan atau peredaan (warm-down), yaitu serial pendek gerakan tubuh untuk mengembalikan kesegaran tubuh setelah menjalani latihan inti.

\section{PERSIAPAN}

Sebelum melakukan latihan harus memperhatikan denyut nadi. Mengetahui denyut nadi sebelum latihan fisik dianjurkan karena berhubungan dengan kerja jantung. Cara untuk menghitung denyut nadi, yaitu dengan menghitung denyut nadi yang ada di leher atau denyut nadi yang ada di pergelangan tangan dalam. Penghitungan denyut nadi yang ada dipergelangan tangan lebih dianjurkan untuk menghasilkan perhitungan yang tepat. Cara penghitungan denyut nada yang ada di pergelangan tangan, yaitu dengan meletakkan jari tengah di atas pergelangan tangan dalam segaris dengan ibu jari atau jari jempol. Selama menghitung denyut nadi mata selalu melihat jam (jam tangan maupun jam dinding yang ada di dalam ruangan). Penghitungan dilakukan selama enam detik dan hasilnya dikalikan sepuluh, atau penghitungan dilakukan selama sepuluh detik dan hasilnya dikalikan enam. Untuk memudahkan perhitungan dan perkaliannya dapat menggunakan tabel perhitungan perhitungan denyut nadi di bawah ini.

TABEL PENGHITUNGAN DENYUT NADI

\begin{tabular}{|c|c|}
\hline 6 Detik Hitungan & Denyut Nadi per Menit \\
\hline 5 & 50 \\
\hline 6 & 60 \\
\hline 7 & 70 \\
\hline 8 & 80 \\
\hline 9 & 90 \\
\hline 10 & 10 \\
\hline 11 & 110 \\
\hline 12 & 120 \\
\hline 13 & 130 \\
\hline 14 & 140 \\
\hline 15 & 150 \\
\hline 16 & 160 \\
\hline 17 & 170 \\
\hline 18 & 180 \\
\hline 19 & 190 \\
\hline 20 & 200 \\
\hline Dan Seterusnya & Dan Seterusnya \\
\hline
\end{tabular}

Gambar perhitungan denyut nadi 
Perhitungan denyut nadi tersebut juga harus disesuaikan dengan umur peserta latihan. Hal ini berkaitan dengan kemampuan dan ketahanan kerja jantung dalam memompakan darah ke seluruh tubuh. Perhitungan denyut nadi ini disebut dengan perhitungan denyut nadi sesuai umur peserta latihan. Untuk mengetahui denyut nadi maksimal yang dapat diacapai adalah dengan mengurangi angka 220 dengan jumlah umur. Setelah mengetahui denyut nadi maksimal terkait umur, maka perlu diketahui rentang denyut nadi yang diperbolehkan untuk melakukan latihan olah tubuh. Di bawah ini adalah rentang denyut nadi yang diperbolehkan untuk melakukan latihan olah tubuh sesuai dengan umur peserta.

TABEL DENYUT NADI LATIHAN SESUAI UMUR
\begin{tabular}{|c|c|c|}
\hline Umur (Tahun) & $\begin{array}{c}\text { Denyut Nadi } \\
\text { Maksimal }\end{array}$ & $\begin{array}{c}\text { Donyut Nadi } \\
\text { Latihan }\end{array}$ \\
\hline 10 & 210 & $137-180$ \\
\hline 15 & 205 & $133-174$ \\
20 & 200 & $130-170$ \\
\hline 25 & 195 & $127-166$ \\
\hline 30 & 190 & $123-162$ \\
\hline 35 & 185 & $120-157$ \\
\hline 40 & 180 & $117-153$ \\
\hline 45 & 175 & $114-149$ \\
\hline 50 & 170 & $110-145$ \\
\hline 55 & 165 & $107-140$ \\
\hline 60 & 100 & $104-130$ \\
\hline 65 & 155 & $101-132$ \\
\hline & & \\
\hline & \multicolumn{2}{|c}{} \\
\hline
\end{tabular}

Gambar denyut nadi latihan sesuai umur

Dalam mempersiapkan latihan olah tubuh dapat dimulai dengan pemeriksaan denyut nadi. Apabila denyut nadi kurang dari 100 denyut per menit maka sebaiknya melakukan jalan cepat atau loncat-loncat selama lima menit sampai mencapai denyut nadi 100 denyut per menit yang merupakan batas terendah denyut nadi yang aman untuk melakukan latihan. Setelah mencapai denyut nadi latihan, maka latihan olah tubuh siap dilaksanakan dengan latihan pemanasan. 
Peregangan atau pemanasan (warm-up) yaitu serial dari gerakan tubuh untuk meningkatkan sirkulasi dan meregangkan otot dengan cara bertahap. Pedoman sebelum melakukan pemanasan dan latihan tubuh adalah sebagai berikut.

a. Cobalah untuk selalu konsentrasi dan santai, jangan menahan nafas, dan bernafaslah secara normal.

b. Mulailah dengan tingkat hitungan yang sedikit kemudian meningkat kehitungan yang banyak sesuai dengan tahapan. Misalnya dalam satu seri latihan dimulai dengan 8 hitungan kemudian pada tahap berikutnya ditingkatkan $2 \times 8$ hitungan sampai banyak hitungan.

c. Konsentrasi pada latihan, jangan biarkan pikiran yang lain memecah konsentrasi. Rasakan setiap pergerakan otot dan tulang-tulang kita selama latihan.

d. Lakukanlah pemanasan ini dengan cara yang halus dan jangan melakukan latihan-latihan dengan gerakan yang disentak-sentak.

e. Usahakan latihan- secara berurut, bisa dimulai dari bagian bawah tubuh menuju ke atas, bisa juga dimulai dari atas menuju ke bagian bawah tubuh.

\section{PEMANASAN JARI DAN PERGELANGAN TANGAN}

a. Patutkan jari-jari tangan satu sama yang lain, putar telapak tangan menjauhi tubuh, luruskan lengan-lengan dan regangkan selama 8 hitungan.

b. Tekan telapak tangan bersamaan dan regangkan pergelangan tangan, pertahankan selama 8 hitungan.

c. Tekan punggung tangan bersamaan dan regangkan pergelangan tangan, pertahankan selama 8 hitungan. 


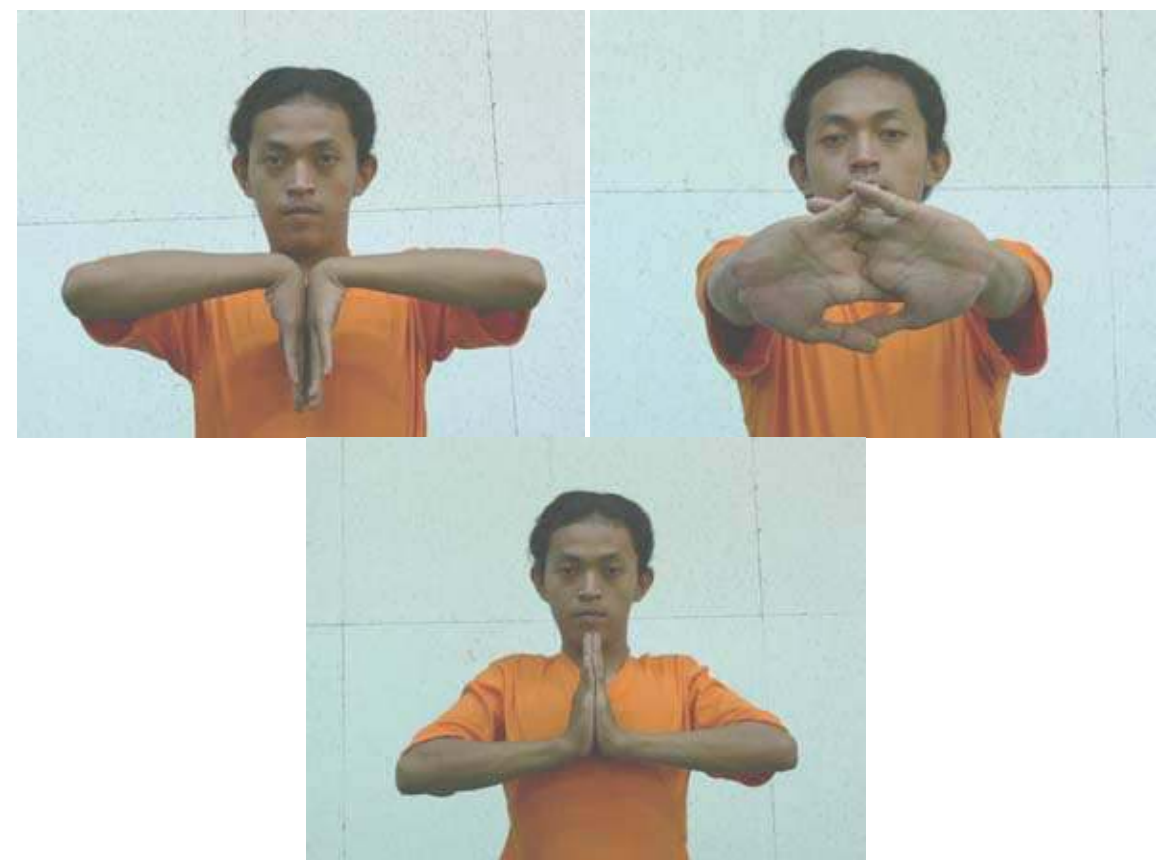

Gambar Pemanasan jari dan pergelangan tangan

\section{PEMANASAN SIKU}

a. Fleksi siku dengan cara tangan kiri memegang pergelangan tangan kanan dan melipat tangan kanan sampai jari tangan kanan menyentuh pundak, pertahankan sampai 8 hitungan. Lakukan bergantian dengan tangan kanan yang memegang pergelangan tangan kiri.

b. Ekstensi siku dengan cara menjulurkan tangan kanan ke depan lurus dan tangan kiri menyangga siku tangan kanan, pertahankan selama 8 hitungan. Lakukan bergantian dengan tangan kiri.

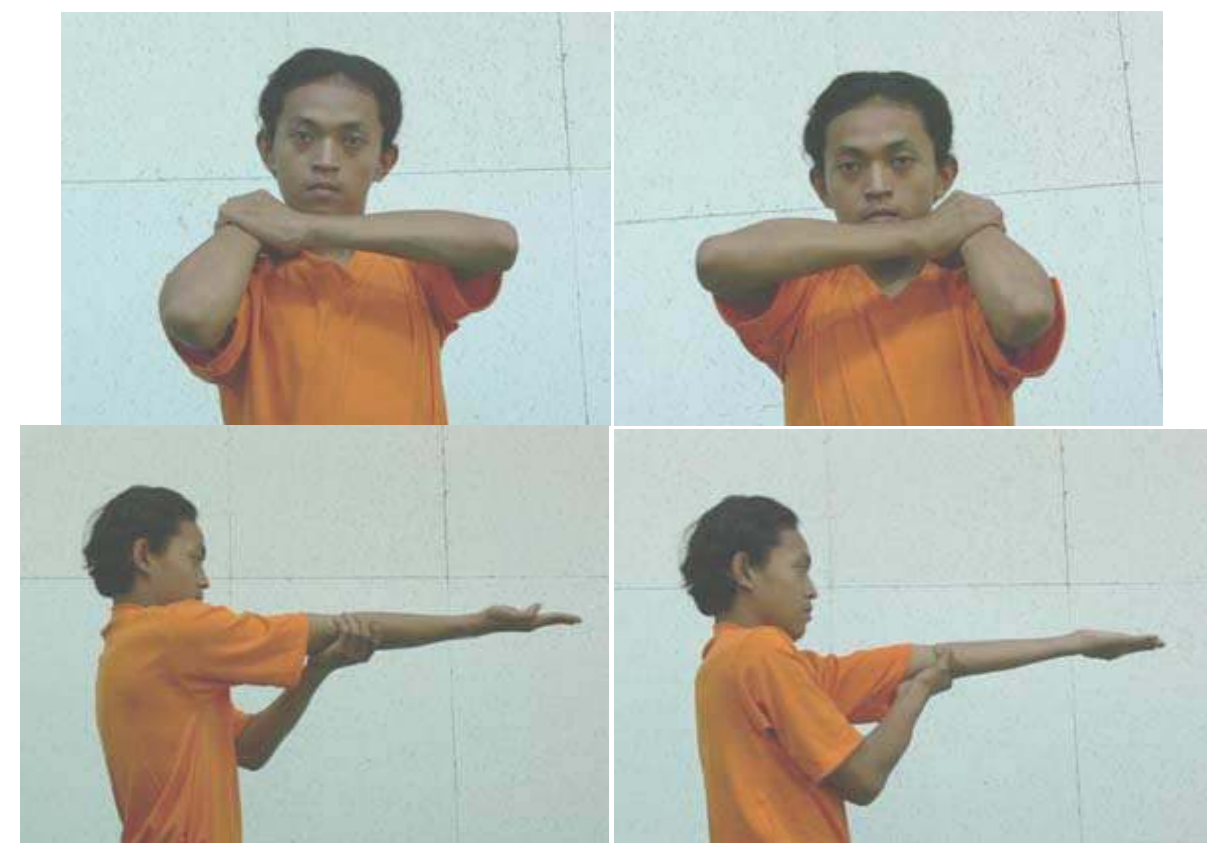

Gambar Pemanasan siku 
a. Silangkan lengan-lengan di depan tubuh dan genggamlah bahu-bahu yang berlawanan, pertahankan selama 8 hitungan.

b. Letakkan siku kanan di belakang kepala dan gunakan tangan kiri untuk membuat topangan regangan, pertahankan selama 8 hitungan.

c. Letakkan siku kiri di belakang kepala dan gunakan tangan kanan untuk membuat topangan regangan, pertahankan selama 8 hitungan.

d. Letakkan satu tangan di atas kepala dan di belakang punggung. Cobalah untuk mempertemukan jari-jari tangan, buatlah regangan dan tahan selama 8 hitungan dan lakukan bergantian.

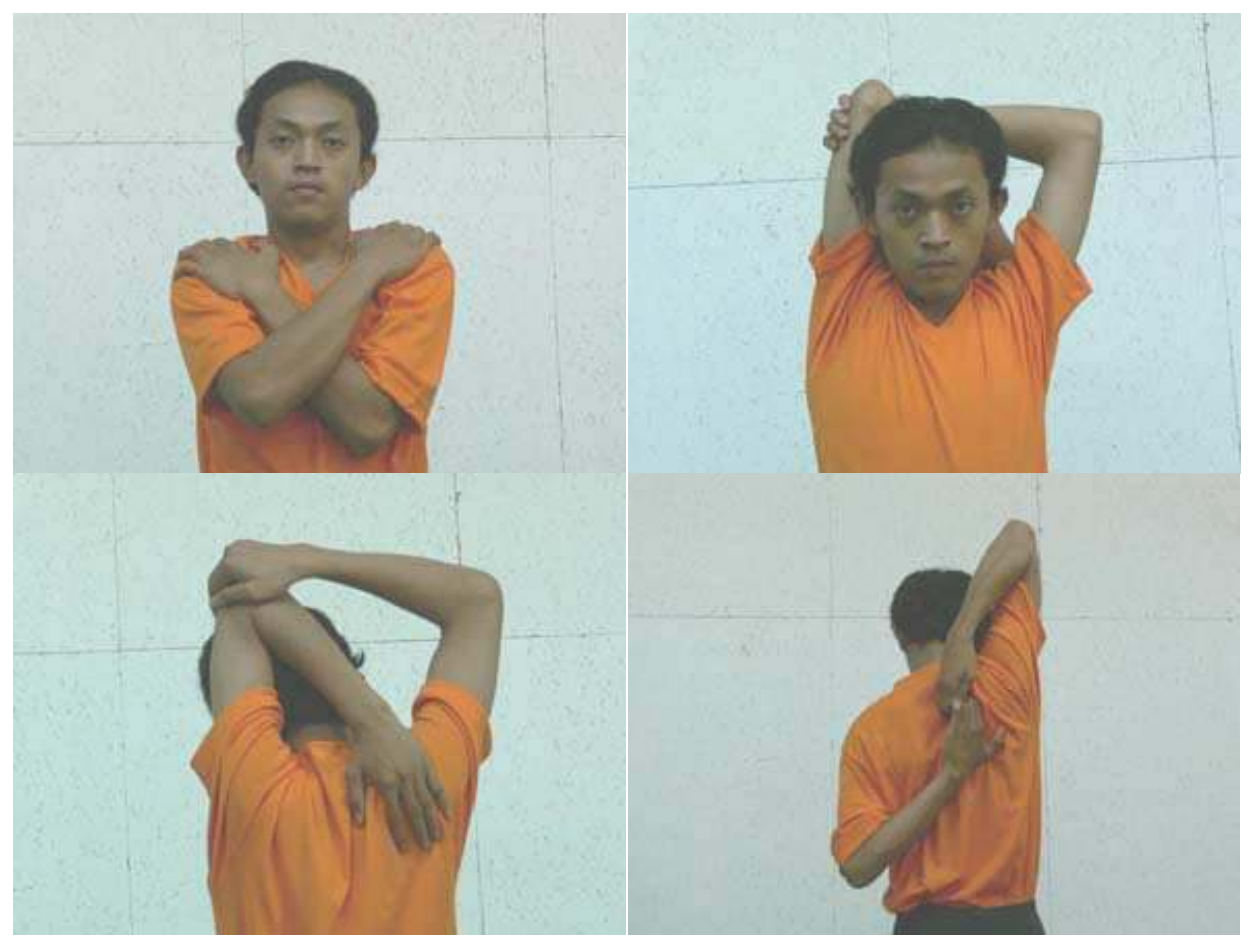

Gambar Pemanasan bahu

\section{PEMANASAN LEHER}

a. Letakkan kepala di atas bahu kiri dan tahan selama 8 hitungan.

b. Letakkan kepala di atas bahu kanan dan tahan selama 8 hitungan.

C. Putar dagu atau tengok ke bahu kiri dan tahan selama 8 hitungan.

d. Putar dagu atau tengok ke bahu kanan dan tahan selama 8 hitungan. 
e. Tarik kepala sejauh mungkin ke depan dan letakkan dagu di atas dada dan tahan selama 8 hitungan.

f. Tarik kepala sejauh mungkin ke belakang, sentuhkan belakang kepala ke bahu dan tahan selama 8 hitungan.

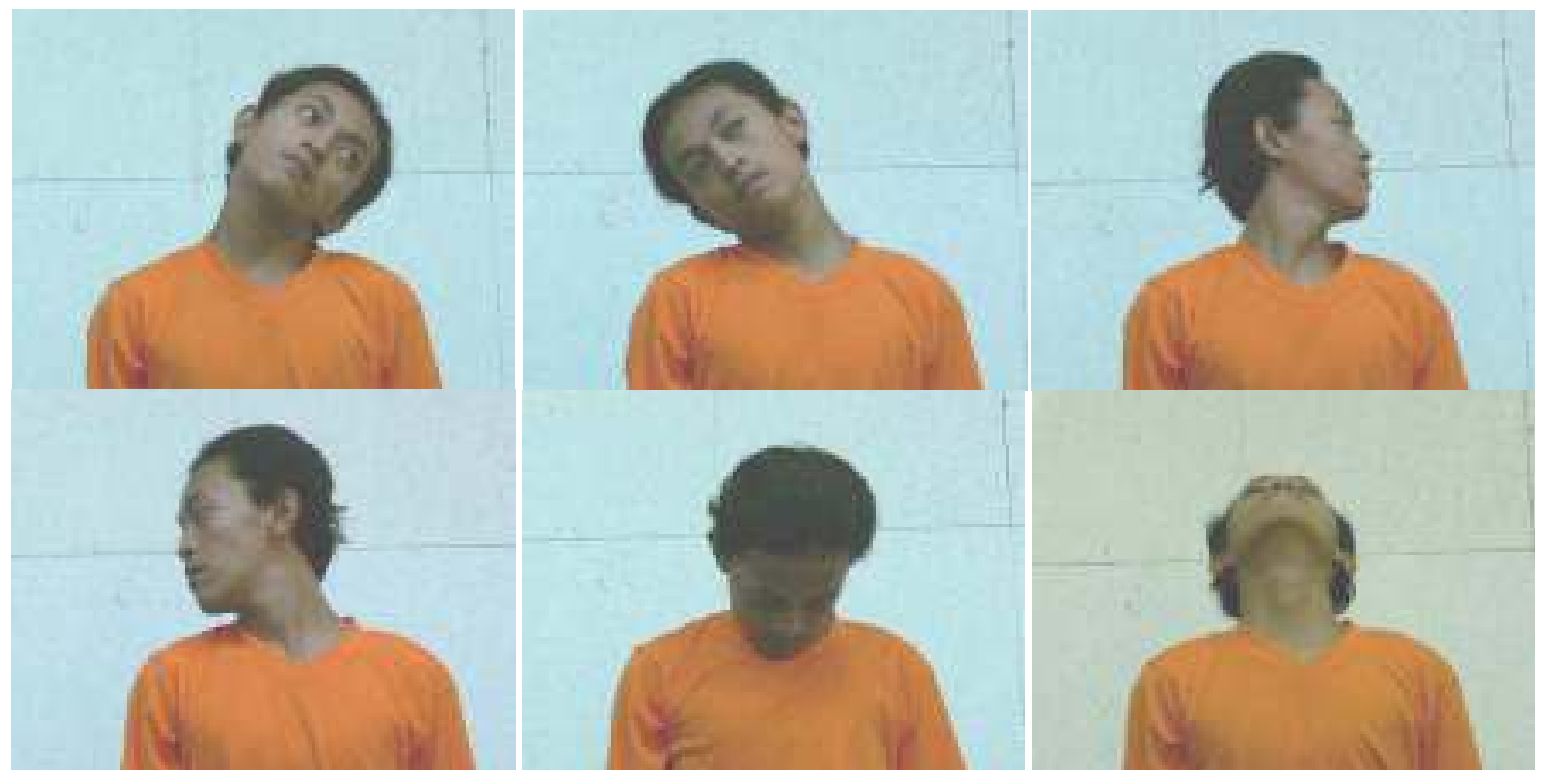

Gambar Pemanasan leher

\section{PEMANASAN BATANG TUBUH}

a. Kedua tangan di pinggang dan bengkokkan badan ke samping kanan, tahan selama 8 hitungan.

b. Kedua tangan di pinggang dan bengkokkan badan ke samping kiri, tahan selama 8 hitungan.

c. Kedua tangan di pinggang dan bengkokkan badan ke belakang, tahan selama 8 hitungan.

d. Kedua tangan di pinggang dan bengkokkan ke depan, tahan selama 8 hitungan. 


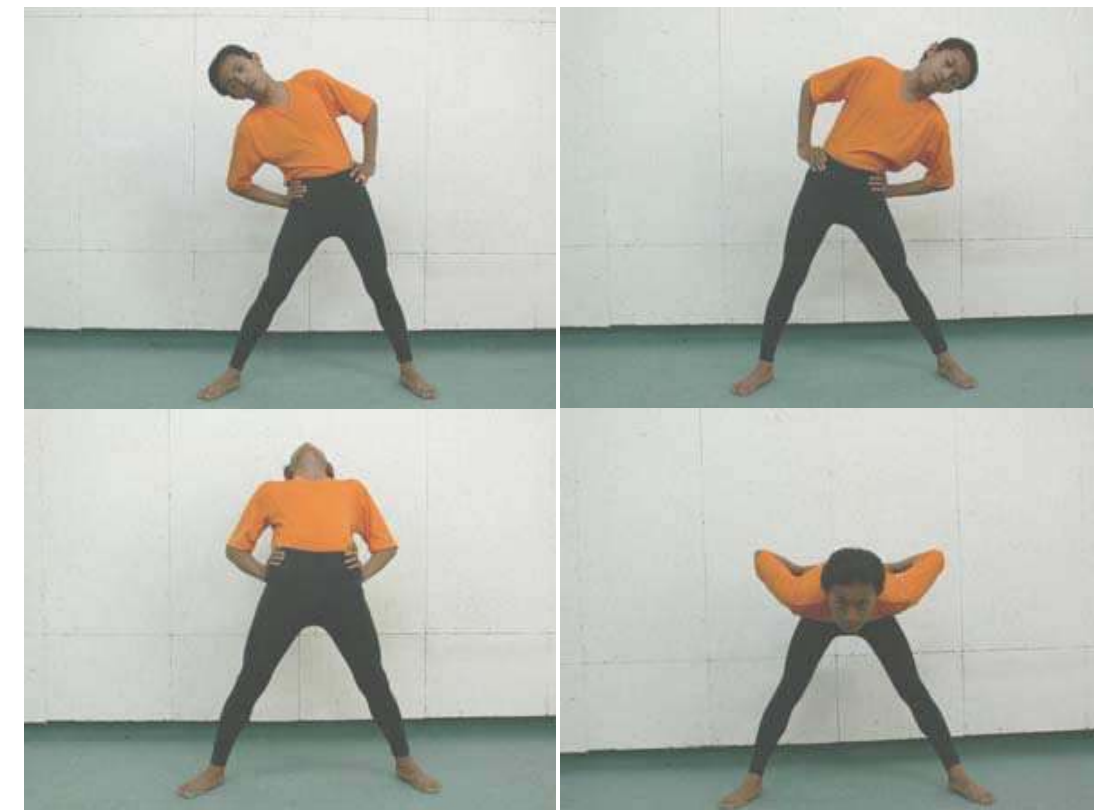

Gambar Pemanasan batang tubuh

\section{PEMANASAN TUNGKAI KAKI DAN PUNGGUNG}

a. Berdiri mengangkang sejauh $+80-100 \mathrm{Cm}$, capailah tungkai kaki kanan, tahan selama 8 hitungan.

b. Berdiri mengangkang sejauh $+80-100 \mathrm{Cm}$, capailah tungkai kaki kiri, tahan selama 8 hitungan.

c. Berdiri mengangkang sejauh $+80-100 \mathrm{Cm}$, capailah bagian tengah dengan membungkukan badan ke depan, tahan selama 8 hitungan.
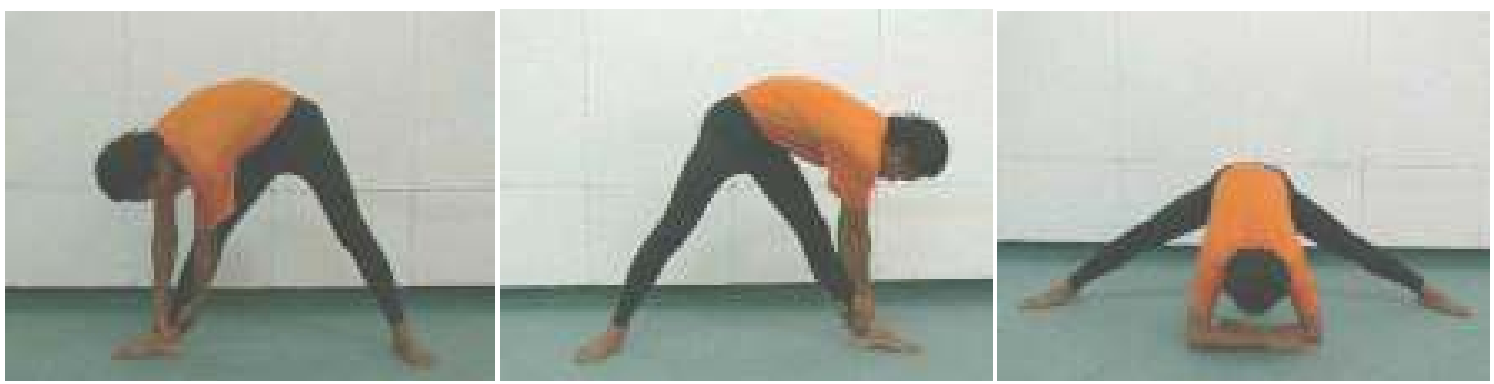

Gambar Pemanasan tungkai kaki dan punggung 1

d. Kedudukan jongkok dengan bertumpu pada ujung telapak kaki, telapak tangan menempel alas dan tangan lurus di sisi luar kanan dan kiri tubuh, tahan selama 8 hitungan. 
e. Kedudukan duduk, telapak kaki menapak sempurna pada alas, dan telapak tangan menempel atau menyentuh pada alas, tahan selama 8 hitungan.

f. Telapak kaki menapak sempurna pada alas, badan membungkuk, jari tangan memegang erat pergelangan kaki dan kepala mencium lutut, tahan selama 8 hitungan.
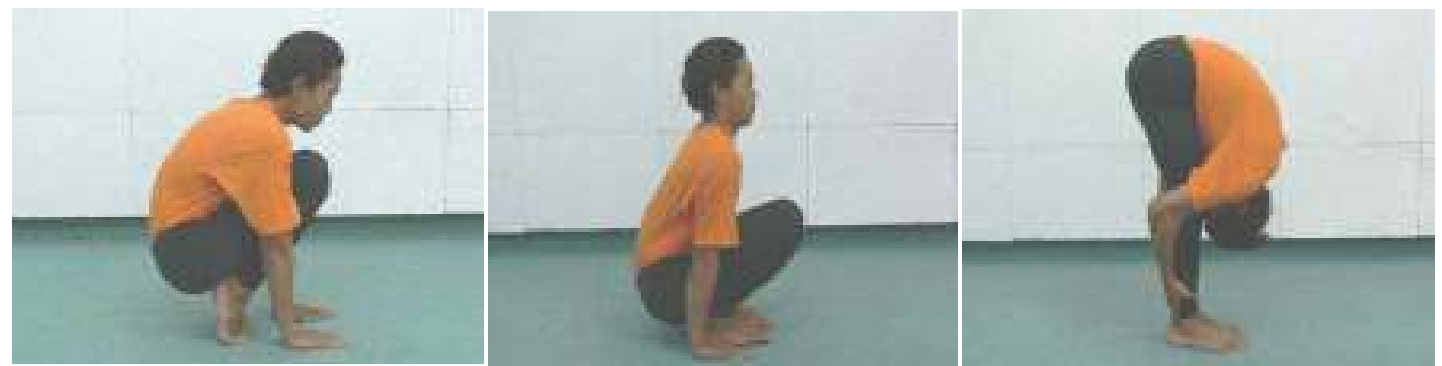

Gambar Pemanasan tungkai dan punggung 2

PEMANASAN PERGELANGAN KAKI, TUNGKAI, DAN PUNGGUNG

a. Fleksikan pergelangan kaki kanan, gunakan kedua tangan untuk memberikan tekanan regangan, tahan selama 8 hitungan.

b. Ekstensikan pergelangan kaki kanan, gunakan kedua tangan untuk melemaskan, tahan selama 8 hitungan.

c. Fleksikan pergelangan kaki kiri, gunakan kedua tangan untuk memberikan tekanan regangan, tahan selama 8 hitungan.

d. Ekstensikan pergelangan kaki kiri, gunakan kedua tangan untuk melemaskan, tahan selama 8 hitungan.

e. Fleksikan lutut tungkai kanan, gunakan kedua tangan untuk menarik lutut ke dada, dan tahan selama 8 hitungan.

f. Ekstensikan lutut tungkai kanan, gunakan kedua tangan untuk menjauhkan lutut dari dada, dan tahan selama 8 hitungan.

g. Fleksikan lutut tungkai kiri, gunakan kedua tangan untuk menarik lutut ke dada, dan tahan selama 8 hitungan.

h. Ekstensikan lutut tungkai kiri, gunakan kedua tangan untuk menjauhkan lutut dari dada, dan tahan selama 8 hitungan. 

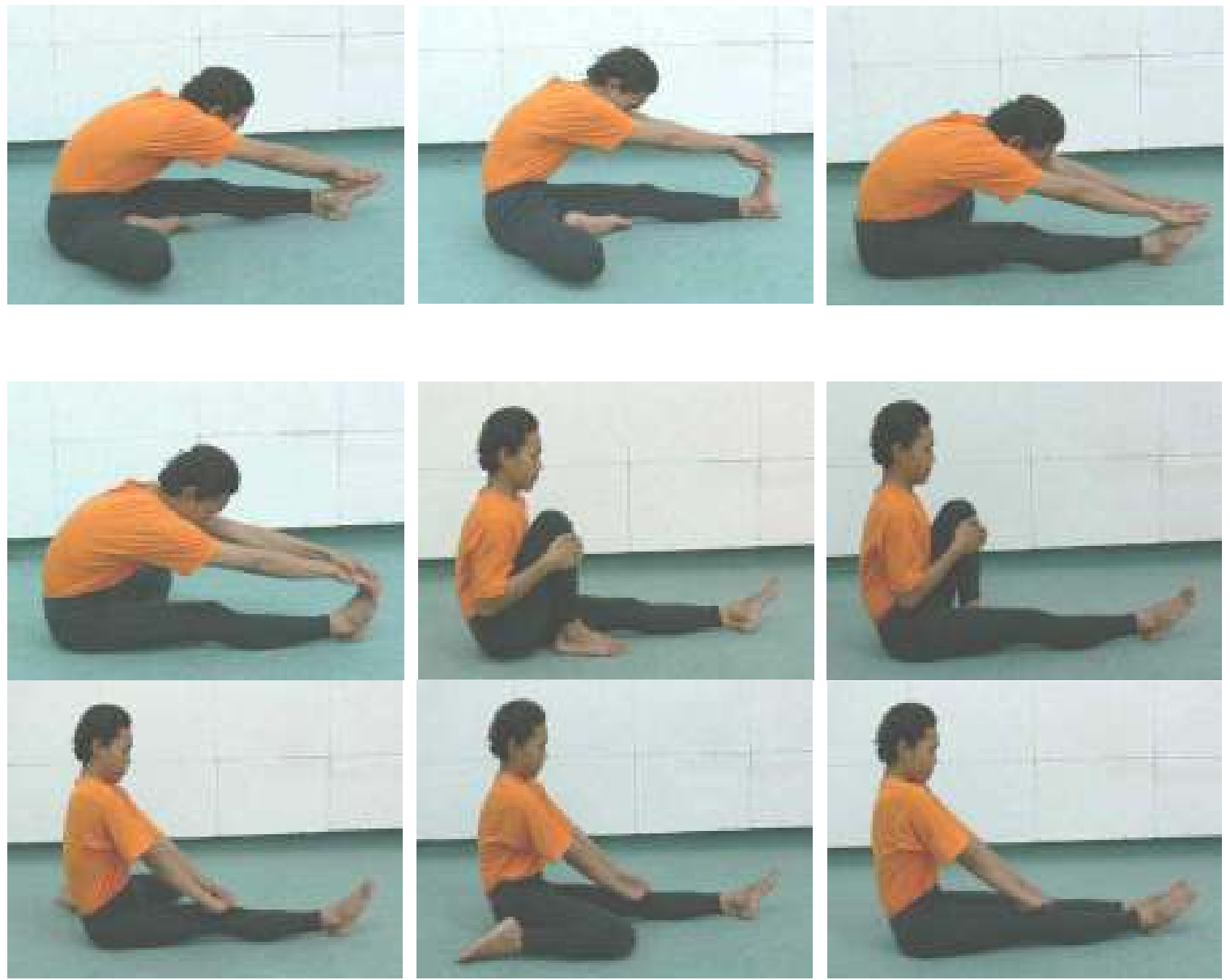

Gambar Pemanasan pergelangan kaki, tungkai, punggung

\section{LATIHAN INTI}

Latihan Olah tubuh inti yaitu serial pokok dari gerakan yang akan dilatih sesuai dengan tujuan membentuk ketahanan tubuh, kelenturan tubuh, dan ketangkasan fisik.

\section{KETAHANAN}

Ketahanan adalah toleransi suatu otot terhadap stress dimana suatu otot dapat mempertahankan penampilannya pada beban kerja tertentu. Latihan ini bertujuan untuk mengembangkan kekuatan bagi respon otot. Dalam latihan olah tubuh ketahanan ini difokuskan pada kekuatan otot perut, tangan, dan kaki.

Pedoman dalam melakukan latihan olah tubuh ketahanan adalah sebagai berikut. 
a. Coba untuk konsentrasi dan konsekuen dalam latihan ini.

b. Ajaklah teman sebagai patner ataupun sebagai pengawas dalam latihan.

C. Untuk latihan gerak tertentu, pergunakan matras sebagai pelindung maupun sebagai alas latihan.

d. Lakukan dengan rileks dan jangan terburu-buru. Prinsip dari dasar dari latihan ini adalah pengulangan-pengulangan secara rutin.

\section{KETAHANAN OTOT PERUT}

a. Posisi telungkup dan naikkan badan bagian atas, lakukan 8 hitungan

b. Posisi telungkup dan naikkan badan bagian bawah, lakukan 8 hitungan

c. Posisi terlentang dan lakukan kayang dengan topangan bahu dan kepala

d. Posisi terlentang dan lakukan kayang dengan topangan kaki dan tangan, lakukan 8 hitungan

e. Posisi terlentang dan lakukan kayang dengan topangan kaki dan tangan, angkat salah satu kaki, lakukan 8 hitungan secara bergantian.

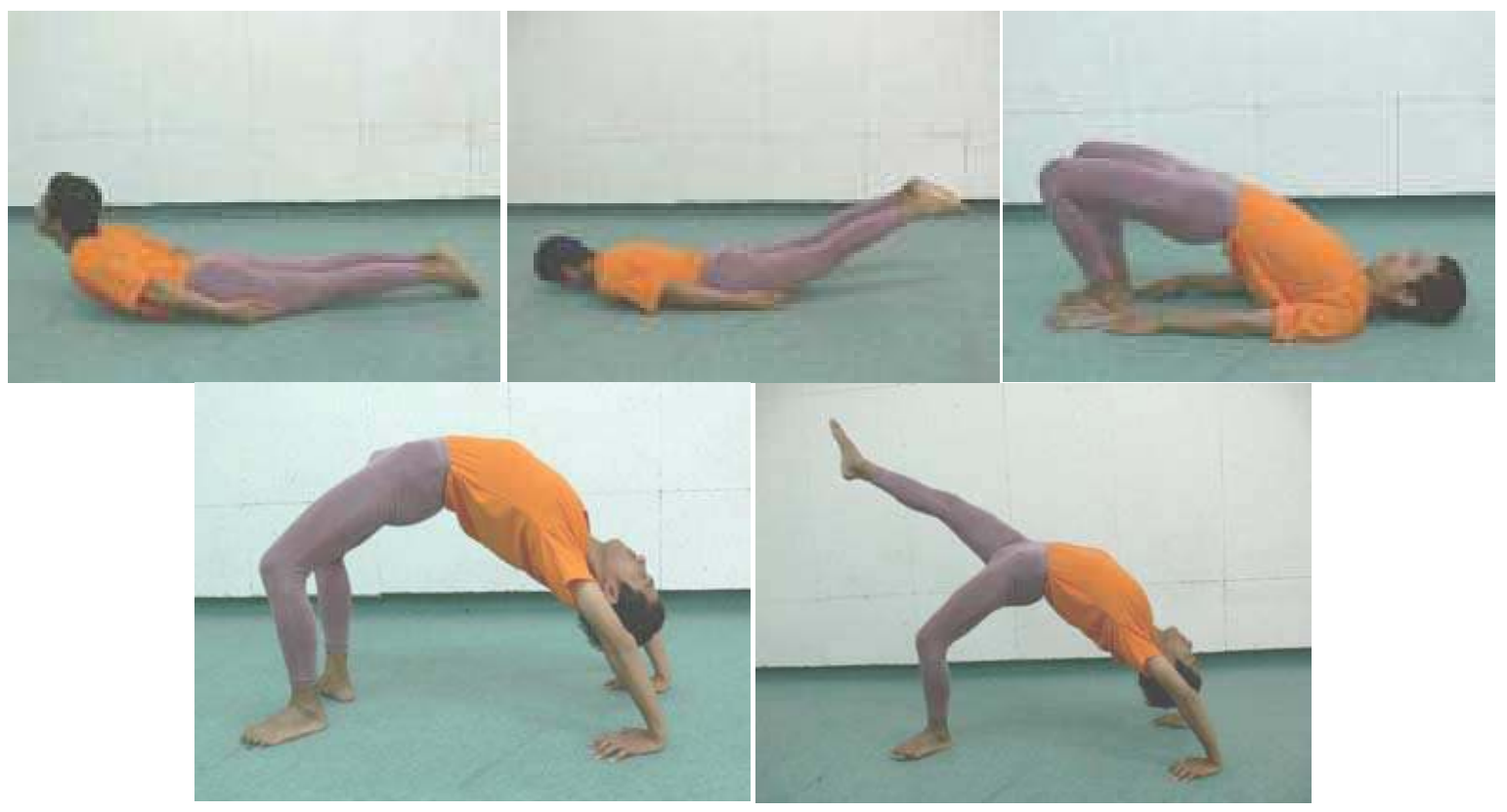

Gambar Latihan otot perut 


\section{KETAHANAN OTOT PERUT DAN PINGGANG}

a. Posisi terlentang dan lakukan sit-up, lakukan 8 hitungan

b. Posisi terlentang dan angkat kaki tegak lurus, tangan terbuka di samping badan, turun kaki ke samping kanan dan kiri bergantian, lakukan 8 hitungan.

c. Posisi terlentang dan cium lutut dalam-dalam, lakukan 8 hitungan

d. Posisi terlentang dan cium lutut dalam-dalam dengan tungkai diangkat melampaui kepala, lakukan 8 hitungan

e. Posisi terlentang dan tungkai diangkat terbuka melampaui kepala, lakukan 8 hitungan.
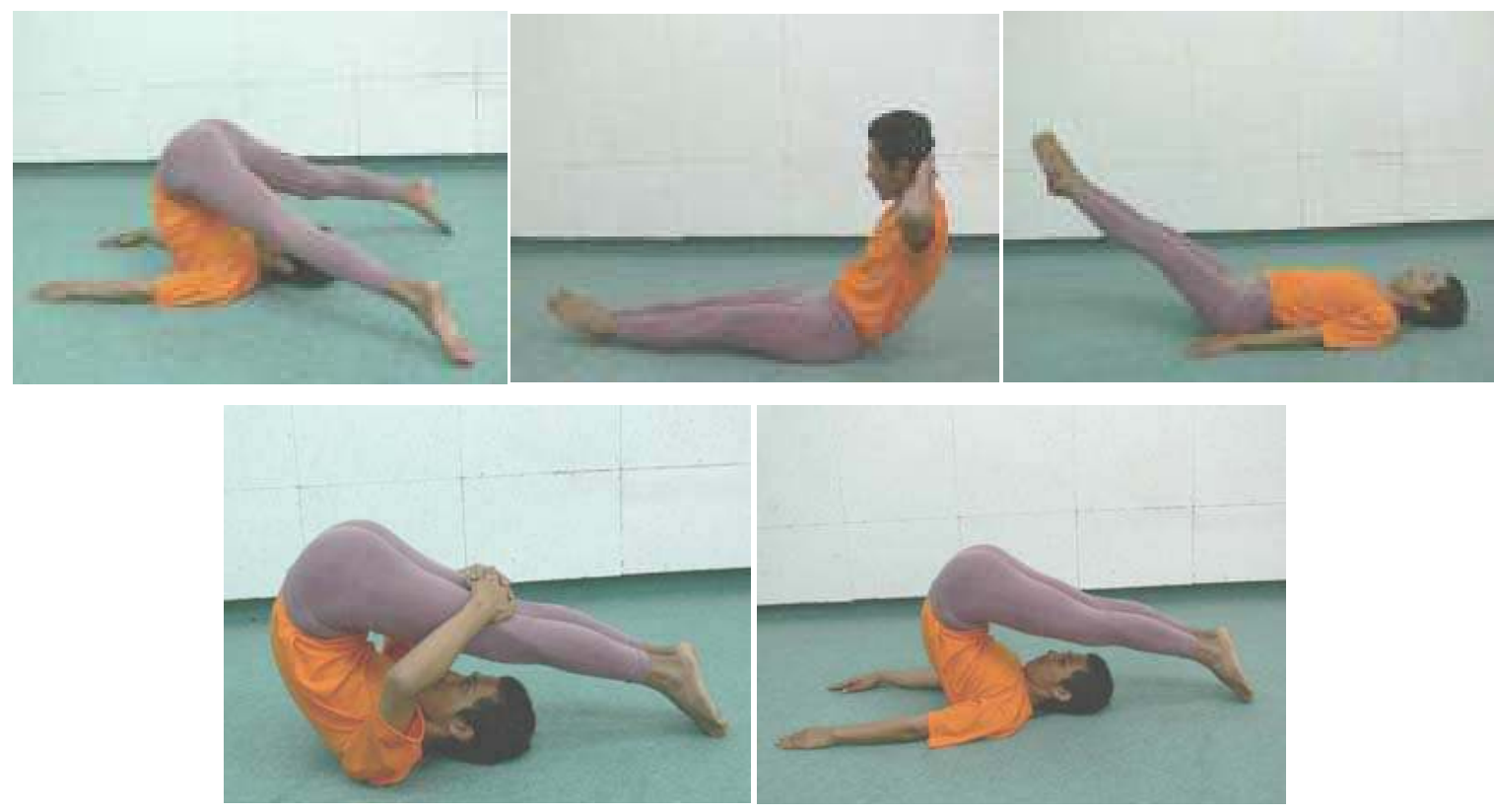

Gambar Latihan otot perut dan pinggang

\section{KETAHANAN KAKI, LUTUT, DAN TANGAN}

a. Posisi duduk satu kaki diangkat tahan 2 detik, lakukan 8 hitungan dan kaki bergantian.

b. Posisi duduk, kaki dan tangan dibuka dan ditutup, lakukan 8 hitungan dan bergantian.

C. Posisi terlentang, kaki dan tangan dibuka dan ditutup, lakukan 8 hitungan dan bergantian. 
d. Posisi berdiri pada lutut, badan tegap dan condongkan ke belakang tahan 2 detik dan kembali tegap, lakukan 8 hitungan.

e. Posisi tidur miring topang badan dengan satu tangan, angkat dan turunkan badan, lakukan 8 hitungan dan bergantian.

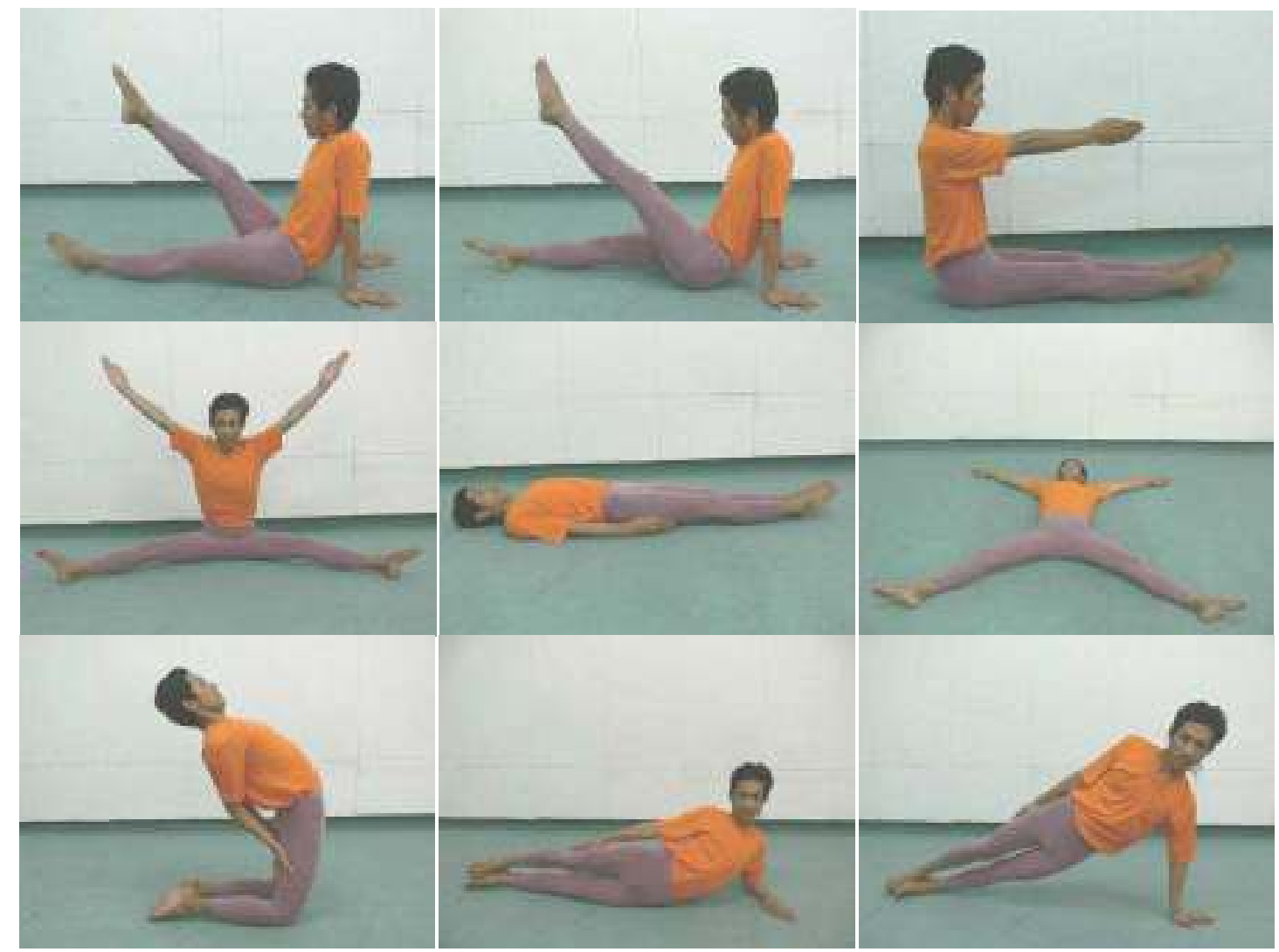

Gambar Latihan kaki, lutut, dan tangan

\section{KETAHANAN LENGAN, BAHU, DAN DADA}

a. Push up dengan kaki rapat di lantai 8 hitungan

b. Push up dengan kaki terbuka di lantai 8 hitungan

C. Push up kedua lengan lurus ke atas dan kedua tungkai kaki jinjit.

d. Push up kedua lengan lurus ke atas dan salah satu kaki ditekuk turun naik 8 hitungan 


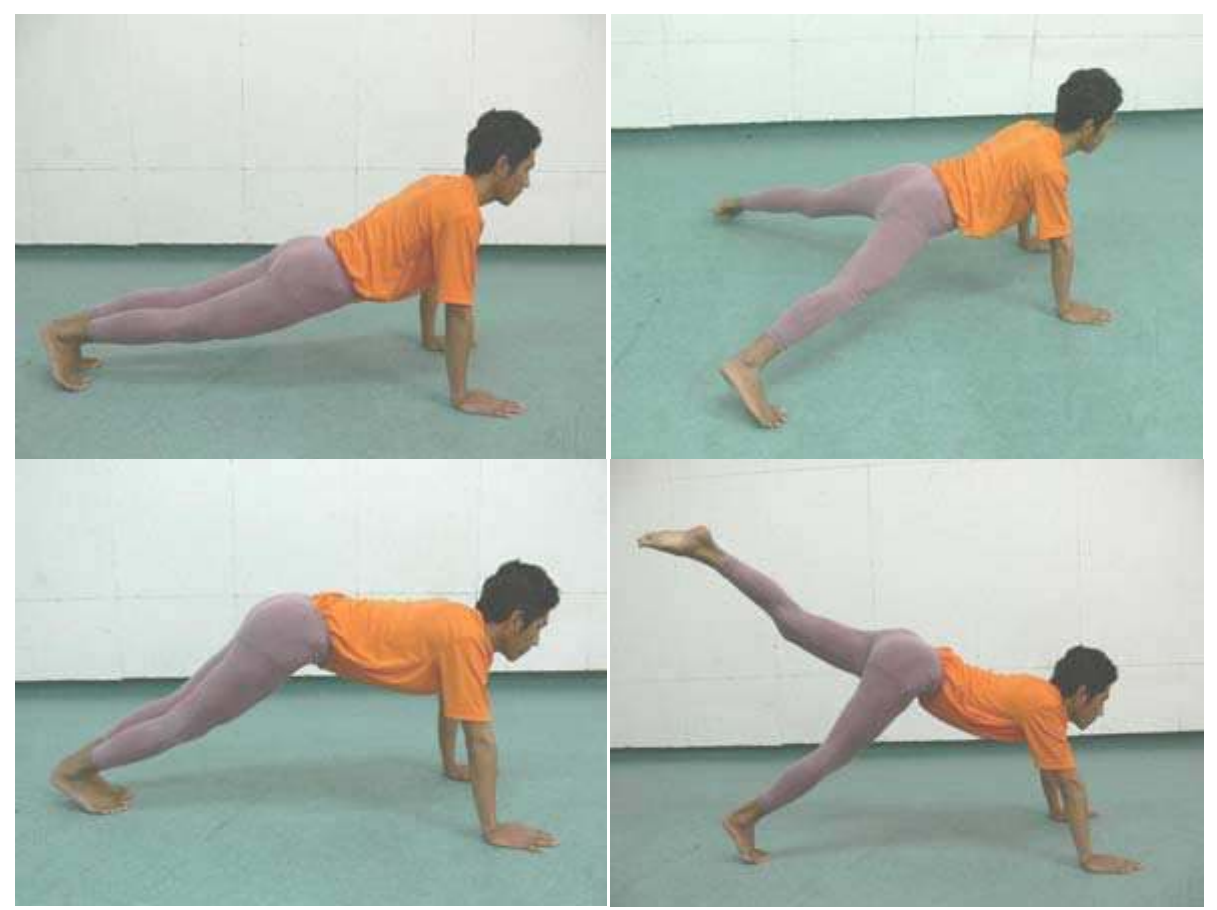

Gambar Latihan lengan, bahu, dan Dada

\section{KELENTURAN}

Kelenturan adalah kelemah-lembutan atau kekenyalan dari otot dan kemampuannya untuk meregang cukup jauh agar memungkinkan persendian dapat beraksi dengan lengkap dalam jarak normal dan dari gerakan ini tidak menyebabkan cedera. Kelenturan tubuh manusia sangat dipengaruhi oleh kelenturan tulang punggung, kaki dan tangan. Latihan ini difokuskan pada latihan tulang punggung, kaki, dan tangan. Pedoman dalam melakukan latihan olah tubuh kelenturan ini adalah sebagai berikut.

a. Lakukan latihan ini dalam tempo yang lambat pada tahap permulaan, dan yang terpenting adalah dapat merasakan pergerakan ruas demi ruas tulang punggung. Setelah dapat merasakan dengan betul tingkatkan kecepatannya dan secara bertahap melambat kembali sampai diam.

b. Latihan ini tidak ada patokan waktu dan hitungan, tetapi lebih pada pencapaian hasil. 
c. Latihlah setiap sesi latihan dengan benar, jangan terburu-buru pindah ke sesi selanjutnya.

d. Bila anda melakukan gerakan menunduk, usahakan kepala lebih dahulu merendah. Sedangkan kalau gerakan menaik usahakan gerakkan itu berawal dari bagian dasar tulang punggung.

\section{KELENTURAN CEMBUNG, CEKUNG, DAN DATAR TULANG PUNGGUNG}

a. Posisi rukuk tangan di lutut dan bungkukkan punggung. Bengkokkan tulang ekor anda turun dan ke dalam, bulatkan tulang punggung dibagian dada dan bahu serta turunkan kepala dan leher. Bentuklah punggung anda ke dalam posisi secembung-cembungnya.

b. Angkat bagian tulang ekor, kosongkan tulang punggung bagian dada dan bahu, dan tegakkan leher serta kepala anda. Bentuklah punggung ke dalam posisi secekung-cekungnya.

c. Turunkan pinggul, luruskan tulang punggung bagian dada dan bahu sehingga membentuk garis lurus dan tulang ekor.

d. Turunkan leher secukupnya agar berada dalam satu garis lurus dengan tulang punggung di bagian bahu.
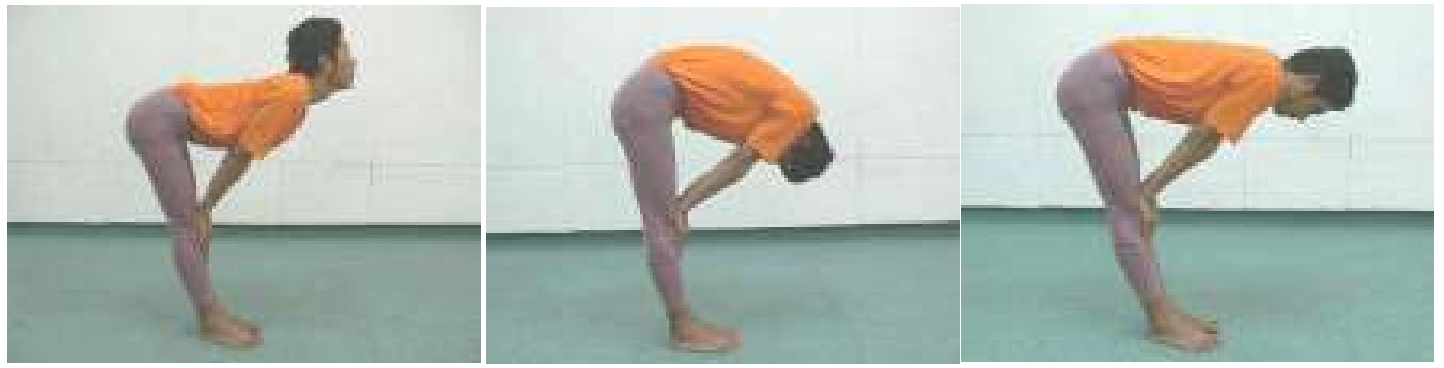

Gambar Latihan cembung, cekung, dan datar tulang punggung

\section{KELENTURAN MEMBULAT, MENCEKUNG, DAN MELURUS}

a. Berdiri dengan dua kaki saling berjauhan $+30 \mathrm{~cm}$. Bengkokkan kaki pelanpelan dan letakkan tangan di atas lutut. Tundukkan kepala, lengkungkan seluruh tulang punggung dan turunkan bagian ekor sehingga posisi tulang punggung membulat. 
b. Posisi badan masih sama, naikkan bagian ekor, kosongkan bagian tengah tulang punggung, dan tegakkan kepala.

c. Ulangi gerakan di atas secara bergantian dari tempo yang lambat sampai cepat kemudian melambat lagi.

d. Ulurkan ruas demi ruas tulang punggung sehingga terasa tulang punggung tegak dan lurus.

e. Pinggul harus kembali pada posisi awal, leher harus berada dalam satu garis lurus dengan ekor dan tulang punggung. Arahkan pandangan mata lurus ke depan. Rasakan posisi telapak kaki dan lutut serta rasakan kemampuan berdiri tubuh anda mulai dari bawah hingga ke atas.

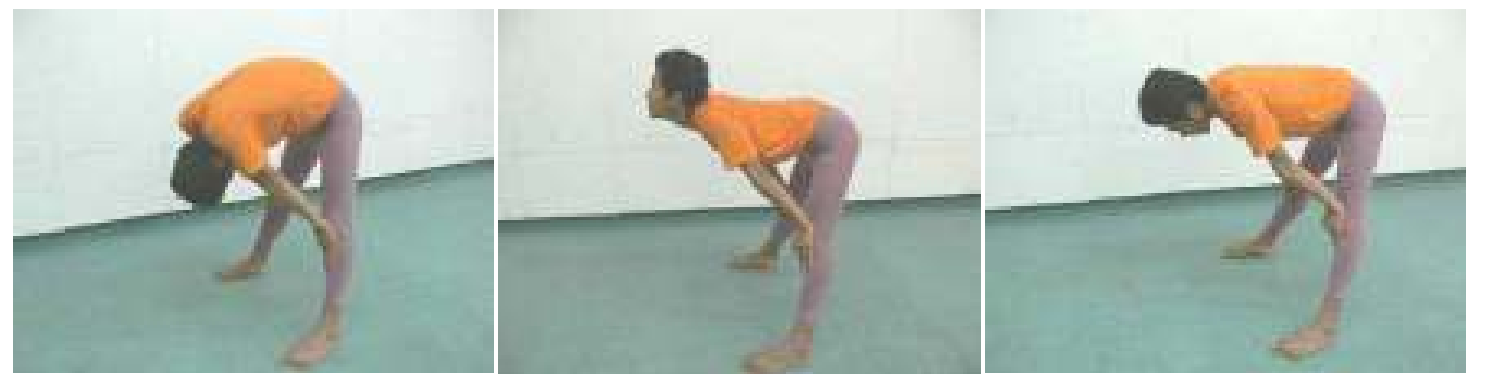

Gambar Latihan membulat, mencekung, dan melurus

\section{KELENTURAN MENGGULUNG DAN MELEPAS}

a. Berdiri dengan kedua kaki direnggangkan, turunkan pinggul dan merendahlah sampai jongkok dengan bertumpukan kekuatan daya dukung lutut.

b. Bungkukkan tubuh bagian atas, tarik tulang ekor masuk ke arah dalam lalu pelan-pelan duduklah dilantai.

c. Luruskan kedua kaki dan gerakkan tulang punggung ke belakang sehingga seluruh punggung terletak di lantai dengan tenang.

d. Gulung seluruh tulang punggung ke depan mulai dari kepala, leher, tulang punggung, dan ekor sehingga membungkuk di atas kaki dan regangkan ke depan.

e. Pelan-pelan berdiri sampai tegak dan mulai jalan dalam gaya lamban.

f. Ulangi latihan ini sampai dapat merasakan fungsi ruas-ruas tulang belakang. 


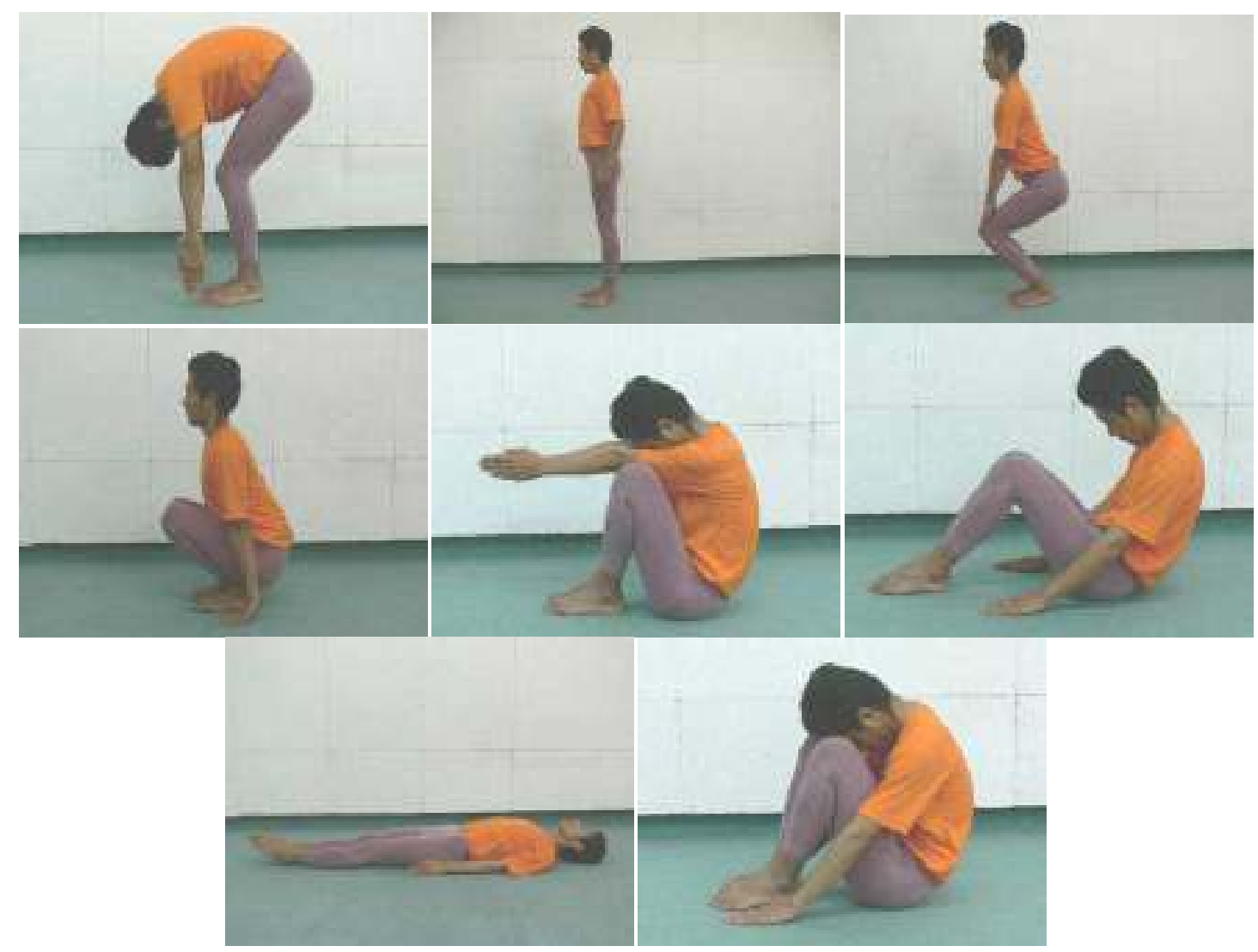

Gambar Latihan menggulung dan melepas

\section{KELENTURAN AYUNAN BANDUL TUBUH ATAS}

a. Berdiri dengan posisi melangkah dan angkatlah kedua lengan tinggi di atas kepala.

b. Bengkokkan tubuh bagian atas yang lurus itu sehingga membentuk sudut yang tepat dengan kaki anda. Pertahankan posisi dan rasakan ketegangan yang terjadi.

c. Lutut-lutut dibengkokkan sedikit, biarkan tubuh bagian atas terjatuh memberat dari bagian tengah tulang punggung dan kemudian hayunkan mendekati dan menjauhi kaki.

d. Lengan-lengan harus mengikuti tubuh bagian atas dan ikut terayun maju dan mundur. Jangan naikkan tubuh bagian atas. Ayunan ini akan mampu menaikkan tulang punggung hanya sejauh sudut membengkoknya yang tepat dari ayunan itu bermula. 
e. Panjang ayunan harus tetap sama dan harus mampu membulat dan meluruskan tulang punggung. Membulat, ketika batang tubuh bagian atas menjauh, dan melurus, ketika tulang punggung mengayun ke depan dan menjauh kalau kedua lengan berada di belakang. Membulat lagi ketika batang tubuh bagian atas jatuh lagi, dan melurus, ketika tulang punggung mengayun ke luar dan menjauh lagi ketika kedua lengan berada di depan.

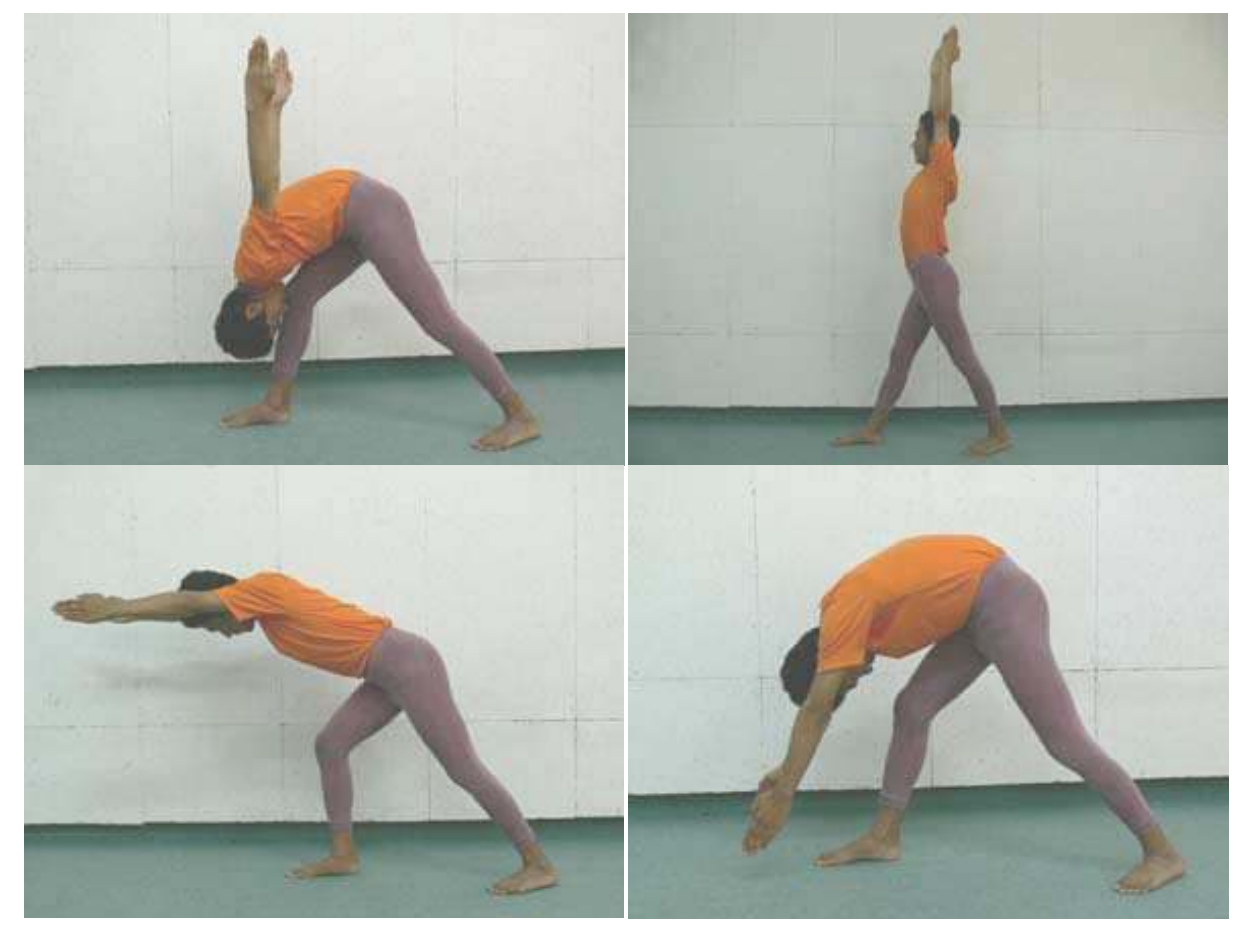

Gambar Latihan ayunan bandul tubuh atas

\section{KETANGKASAN}

Ketangkasan merupakan suatu bentuk latihan olah tubuh yang difokuskan pada keterampilan, kecepatan, dan kegesitan. Ketangkasan sebenarnya hasil pertumbuhan alami dari latihan kelenturan dan ketahanan. Latihan ini akan difokuskan pada konsentrasi gerak.

Pedoman sebelum melakukan latihan olah tubuh ketangkasan ini adalah sebagai berikut. 
a. Menemukan pasangan berlatih untuk melatih teknik-teknik yang ada dengan penuh ketelitian dan kesabaran, sehingga posisi-posisi dan gerak yang dilaksanakan benar-benar tepat.

b. Latihlah pada tiap-tiap teknik dalam suatu rangkaian gerak mulai dari gerak lambat menuju gerak yang cepat.

c. Teknik yang dilatih harus dilakukan dari kanan maupun dari kiri, sehingga benar-benar dapat dikuasai dari semua sudut.

d. Lakukan pergantian posisi.

e. Lakukan dengan tangan dan kaki yang sebaliknya.

\section{LATIHAN CERMIN}

a. Berpasangan dan berhadapan serta ditentukan siapa sebagai cermin dan siapa yang bercermin.

b. Latihan dimulai dari gerak sederhana dan lambat, semakin lama semakin bervariasi dan cepat.

c. Lakukan pergantian, antara cermin dan yang bercermin.
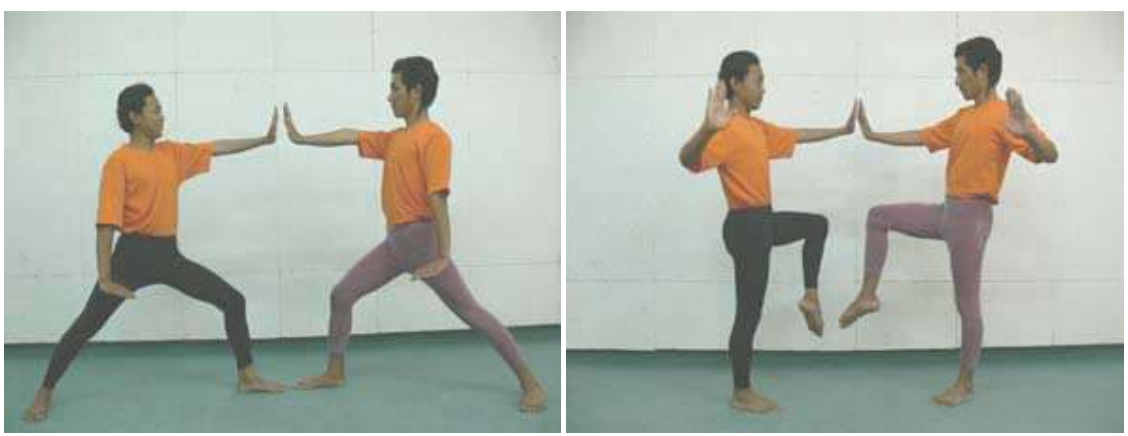

Gambar Latihan cermin

\section{LATIHAN KUDA-KUDA}

a. Lompat terus jongkok dan lakukan sebanyak 8 kali

b. Lompat terus mengangkang dan lakukan sebanyak 8 kali. 


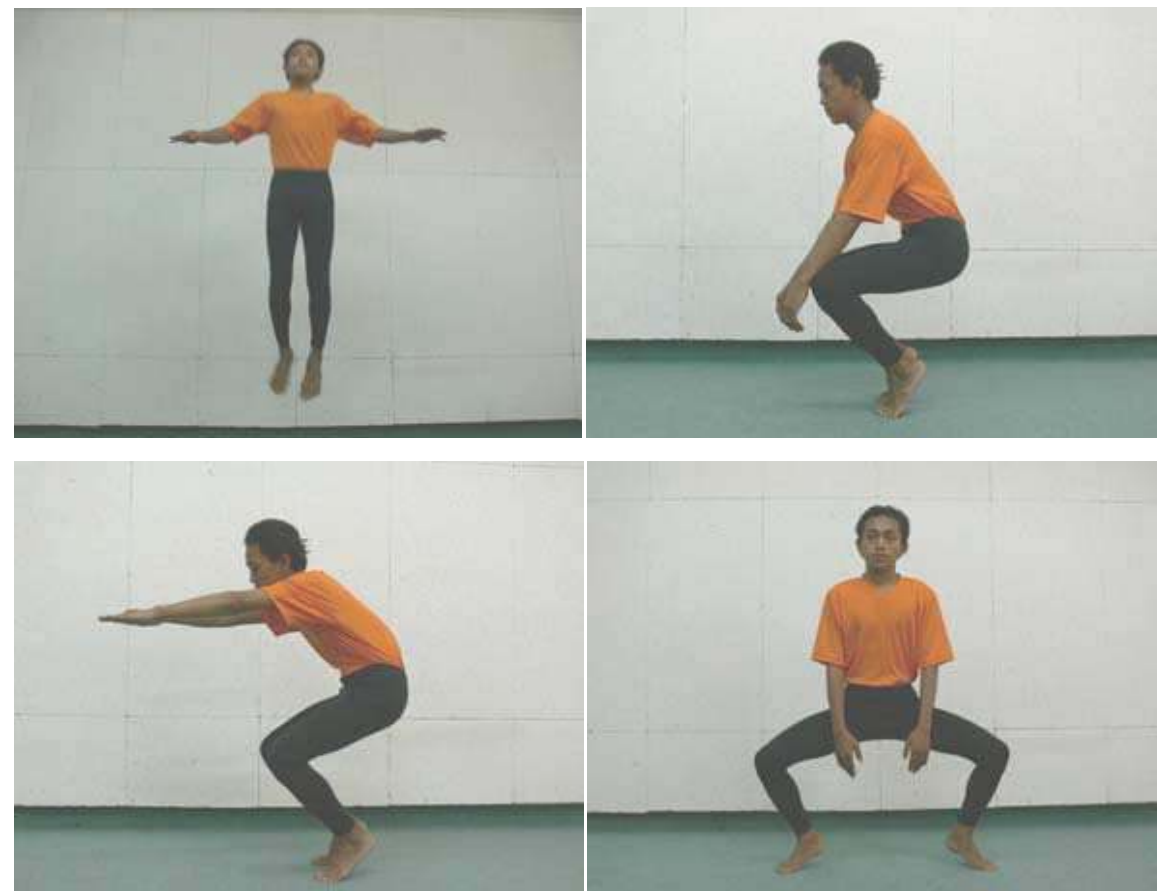

Gambar Latihan kuda-Kuda

\section{PENDINGINAN}

Pendinginan atau peredaan (warm-down) yaitu serial pendek gerakan latihan yang bertujuan untuk menyegarkan kembali kondisi tubuh. Pengenduran otot-otot dilakukan untuk memperbaiki kelenturan tubuh yang menegang akibat latihan inti. Sasaran dari latihan ini adalah sebagai berikut.

a. Mengakhiri setiap latihan dalam suasana yang menyenangkan.

b. Menetapkan suatu serial gerakan dengan maksud untuk mempertahankan penambahan sirkulasi yang ringan, meregangkan otot-otot dan melancarkan peredaran darah, serta menstabilkan pernafasan.

c. Memperbaiki kesadaran diri dari kebutuhan-kebutuhan otot.

Program latihan pendinginan atau peredaan itu adalah sebagai berikut.

a. Berdiri tegak, kaki dibuka $+60 \mathrm{~cm}$, badan condong ke kiri, kaki kanan lurus dan kaki kiri agak ditekuk ke bawah, tangan kanan lurus ke atas di samping kepala dan tangan kiri ditempelkan pada paha kaki kiri, tahan sampai 8 hitungan. Ganti badan condong ke kanan. 

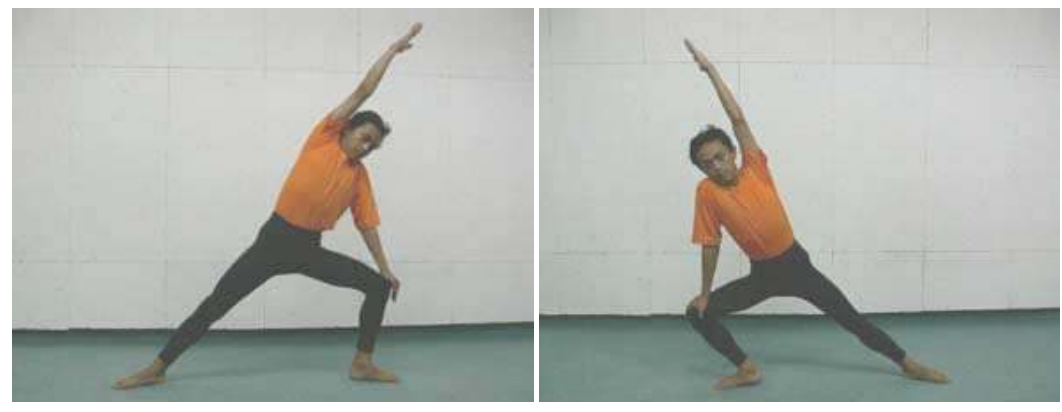

Gambar Pendinginan kaki dan sisi luar badan

b. Posisi berdiri masih sama tetapi badan tegak di tengah dan kedua lengan direntangkan ke kiri dan ke kanan lurus bahu, kaki agak ditekuk ke bawah dan lakukan gerakan mengeper ke atas dan bawah, lakukan selama 8 hitungan.

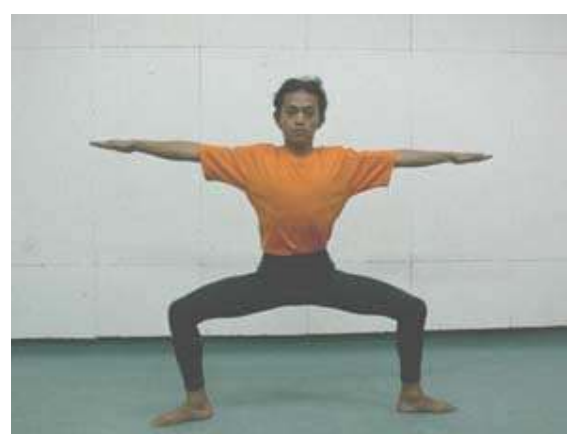

Gambar Pendinginan kaki dan tangan

c. Posisi berdiri masih sama, kedua tangan lurus ke atas kepala dan condongkan badan ke kiri, tahan sampai 8 hitungan. Ganti badan condong ke kanan dengan hitungan yang sama.
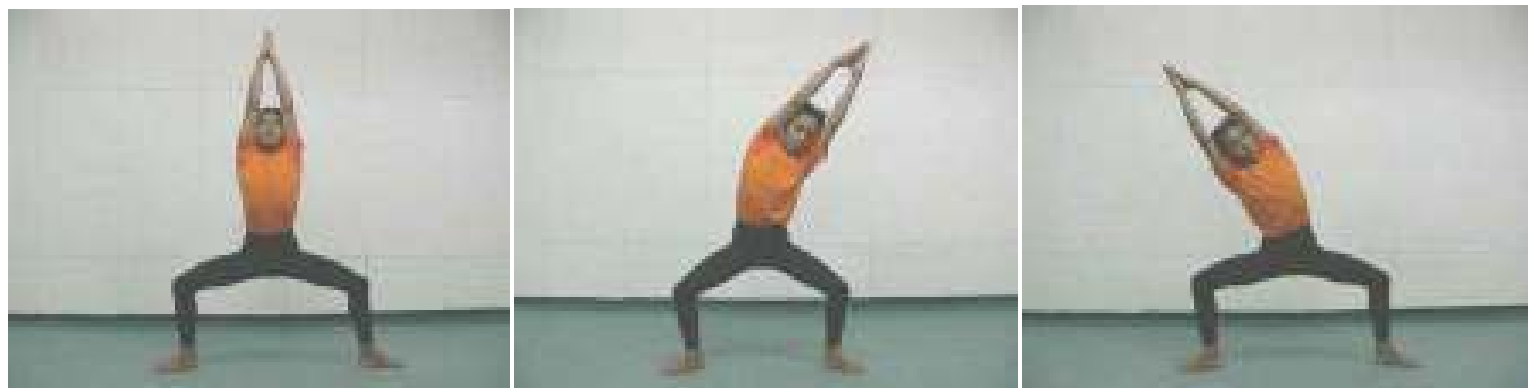

Gambar Pendinginan tangan dan sisi luar badan 
d. Posisi berdiri masih sama, silangkan tangan kanan sejajar bahu di depan dada ke arah kiri dan tangan kiri membantu peregangan tepat pada siku, tahan sampai 8 hitungan. Ganti tangan kiri sejajar bahu di depan dada ke arah kanan dan tangan kanan membantu peregangan tepat pada siku, tahan sampai 8 hitungan.
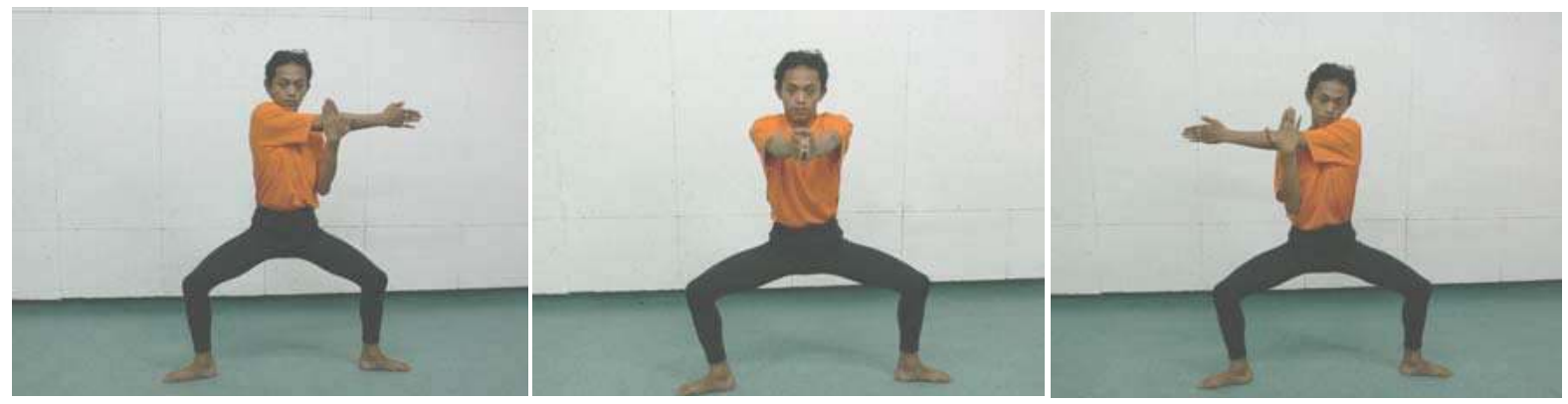

Gambar Pendinginan tangan

e. Posisi berdiri masih sama, tangan kanan lurus ke atas di samping kepala dan tangan kiri menekan kepala kearah kiri, tahan sampai 8 hitungan. Ganti tangan kiri lurus dan tangan kanan menekan kepala ke arah kanan dengan hitungan yang sama.
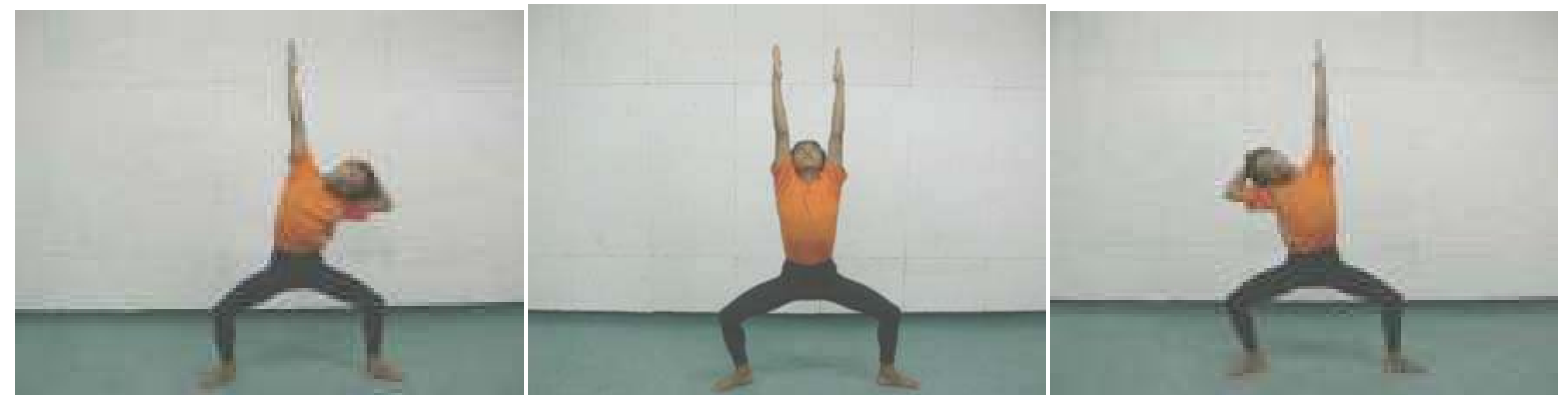

Gerakan Pendinginan leher

f. Posisi berdiri masih sama, langkahkan kaki kanan ke kanan, lutut kanan ditekuk serong kanan, kaki kiri bertumpu pada tumit, badan condong ke kanan, kedua telapak tangan menempel di atas kedua paha dan ayunkan ke bawah sampai 8 hitungan. Ganti dengan kaki kiri langkahkan ke kiri, lutut kiri ditekuk serong kiri, kaki kanan bertumpu pada tumit, badan 
condong ke kiri, kedua telapak tangan menempel di atas kedua paha dan ayunkan ke bawah sampai 8 hitungan.
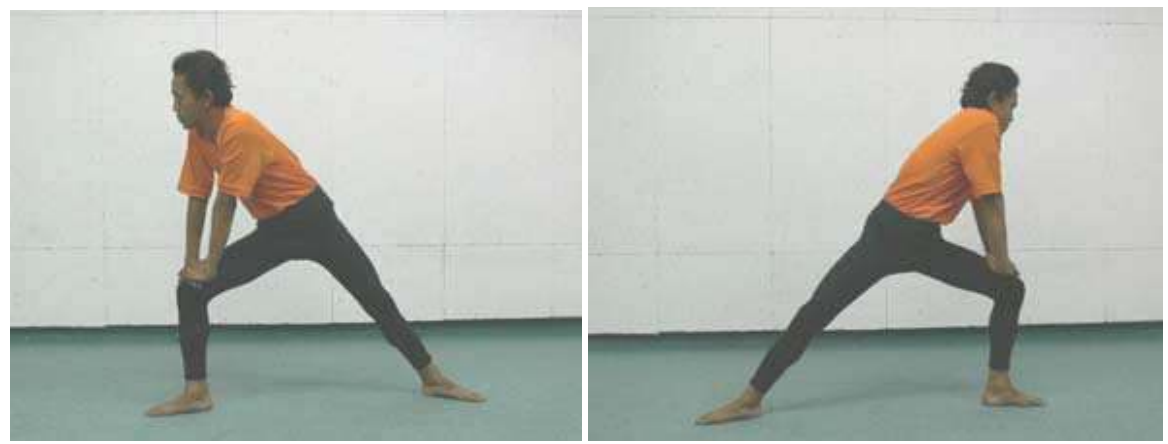

Gambar Pendinginan lutut dan tumit

g. Posisi berdiri masih sama, tangan di samping badan, mulai tangan diangkat lurus ke atas kepala sambil menghirup napas alam 4 hitungan dan menurunkan tangan sambil menghembuskan napas dalam 4 hitungan. Lakukan gerakan ini 4 kali dan gerakan yang terakhir dibarengi dengan menutup kaki.

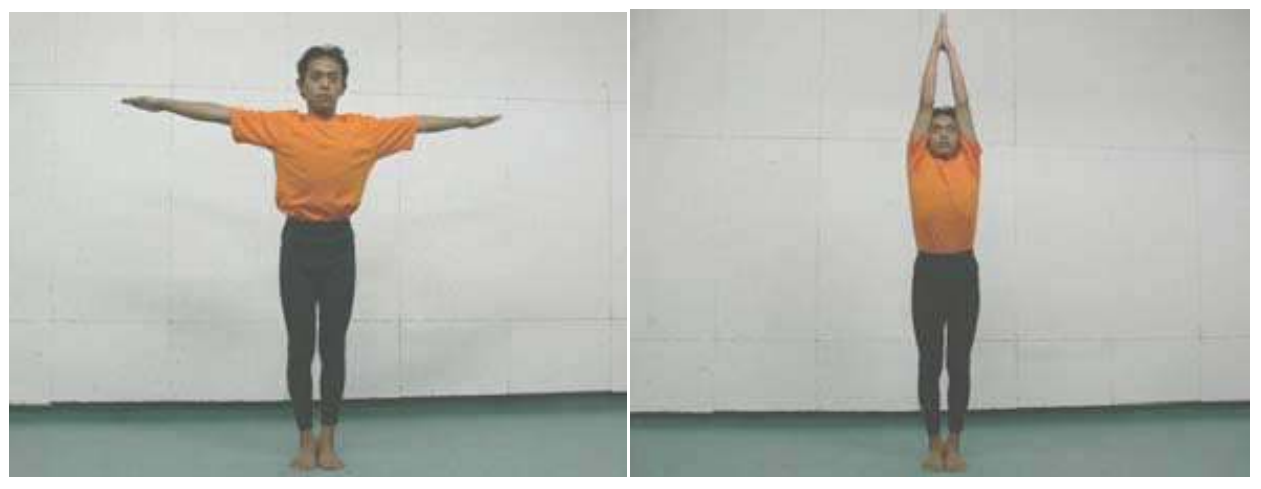

Gambar Pendinginan dengan pernafasan

\section{RELAKSASI}

Relaksasi adalah memposisikan tubuh dalam kondisi yang rileks, tanpa tegangan. Akan tetapi, meskipun tubuh rileks bukan berarti berada dalam keadaan pasif (tanpa bergerak). Relaksasi melepaskan kekangan yang ada dalam tubuh 
melalui gerakan-gerakan lembut yang teratur. Keteraturan gerak seirama dengan nafas sehingga ketegangan otot-otot tubuh kembali mengendur. Relaksasi merupakan hal yang penting bagi semua pemeran. Oto-otot tubuh yang menegang membawa dampak yang kurang baik bagi emosi sehingga mempengaruhi konsentrasi.

Pemeran pemula biasanya sulit bersikap rileks. Hal ini disebabkan ketidaksiapan fisik dan semosi saat berada di hadapan penonton. Dengan kata lain, dalam keadaan rileks, aktor akan menunggu dengan tenang dan sadar dalam mengambil tempat dan melakukan akting. Untuk mencapai relaksasi atau mencapai kondisi kontrol mental maupun fisik diatas panggung, konsentrasi adalah tujuan utama.

Ada bermacam-macam bentuk relaksasi, lakukan relaksasi yang sesuai dengan keadaan pikiran. Relaksasi bisa dilakukan dengan cara tai-chi, yoga. Pada sub bab ini akan dibahas relaksasi dalam bentuk yoga. Yoga sebenarnya adalah seni daya tubuh yang dilakukan melalui perpaduan antara pernafasan, pose tubuh dan konsentrasi sehingga jiwa atau pikiran kita menjadi relaks. Pose tubuh dalam yoga disebut dengan asana. Dasar-dasar dari yoga yang perlu diperhatikan, adalah cinta kasih, kejujuran, kesederhanaan, kesucian, dan tidak gila hormat. Yoga selain sebagai relaksasi juga dipercaya bisa menyembuhkan penyakit.

Pedoman melakukan relaksasi adalah sebagai berikut.

a. Konsentrasi pada nafas, bila perlu rasakan perjalanan udara mulai dari hidung, tenggorokan, dan paru-paru.

b. Santai dan kendorkan semua pikiran, otot-otot, dan jangan ada yang mengganggu atau terjadi ketegangan.

c. Gunakan nafas segitiga, yaitu menghirup, menahan, dan menghembuskan nafas dengan hitungan yang sama.

d. Pilihlah pose-pose yang sesuai dengan kemampuan, jangan memaksakan suatu pose tetapi tidak merasa nyaman.

Pose-pose yoga yang dapat digunakan untuk latihan relaksasi ini adalah sebagai berikut. 
a. Posisi badan telungkup kaki dilipat ke atas, nafas biasa.

b. Tangan menarik kaki yang dilipat tadi sehingga posisi badan seperti busur, goyang-goyangkan pada perut.

C. Ketika menarik dan mengoyangkan badan, nafas ditahan.

d. Pergunakanlah nafas segitiga, yaitu ketika menarik, menahan, dan menghembuskan nafas hitungannya sama. Misalnya menarik nafas dengan 10 hitungan, berarti menahan dan menghembuskan 10 hitungan dan seterusnya.

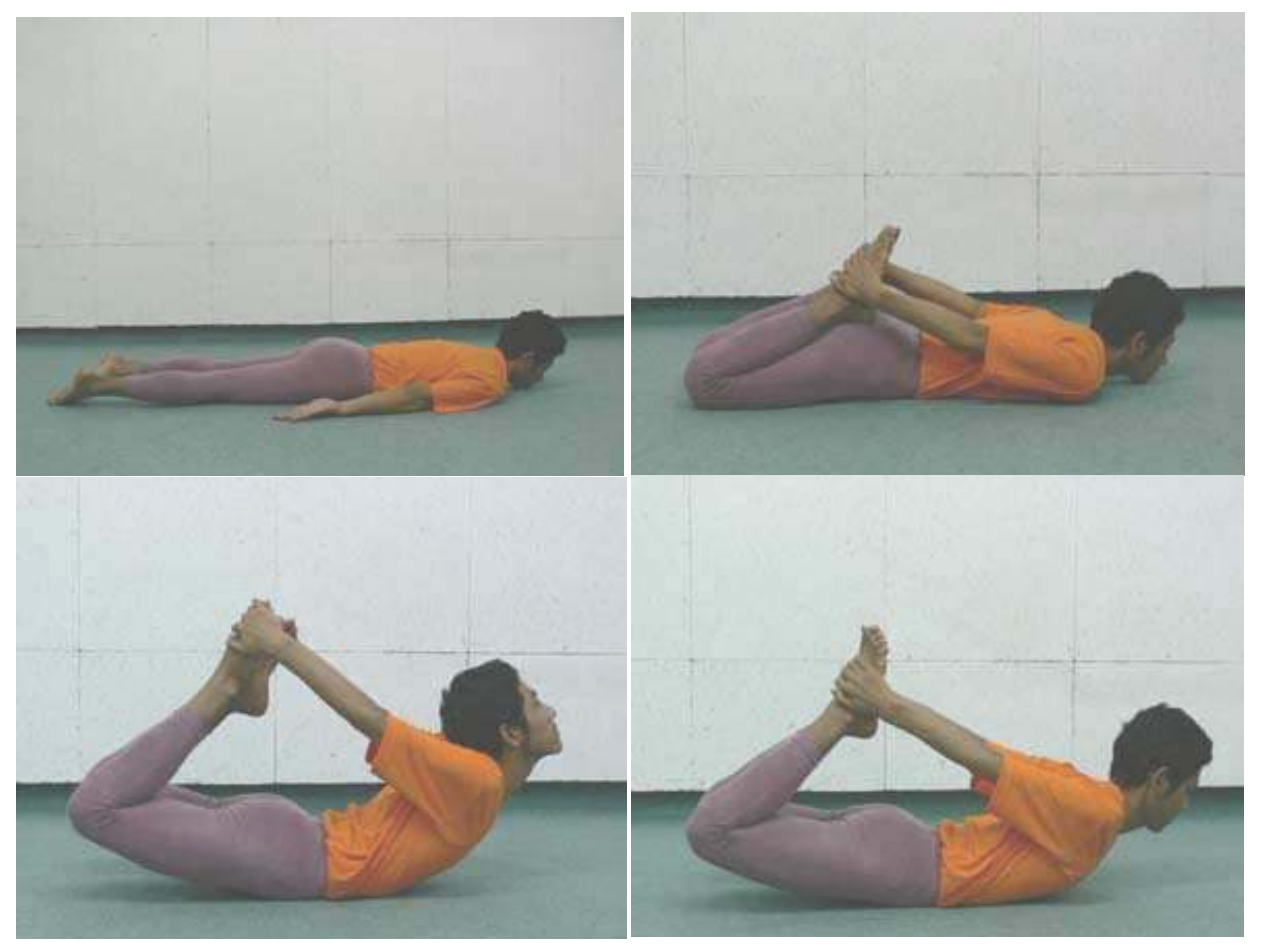

Gambar Pose busur

\section{GARUDASANA (POSE GARUDA)}

a. Posisi duduk kaki dilipat saling menumpuk, tarik nafas diiringi dengan dengan posisi tangan membentang lurus di kanan dan kiri tubuh.

b. Tahan nafas, terus menarik tangan dalam posisi menyembah sambil menghembuskan nafas. Lakukan paling sedikit 8 kali. 


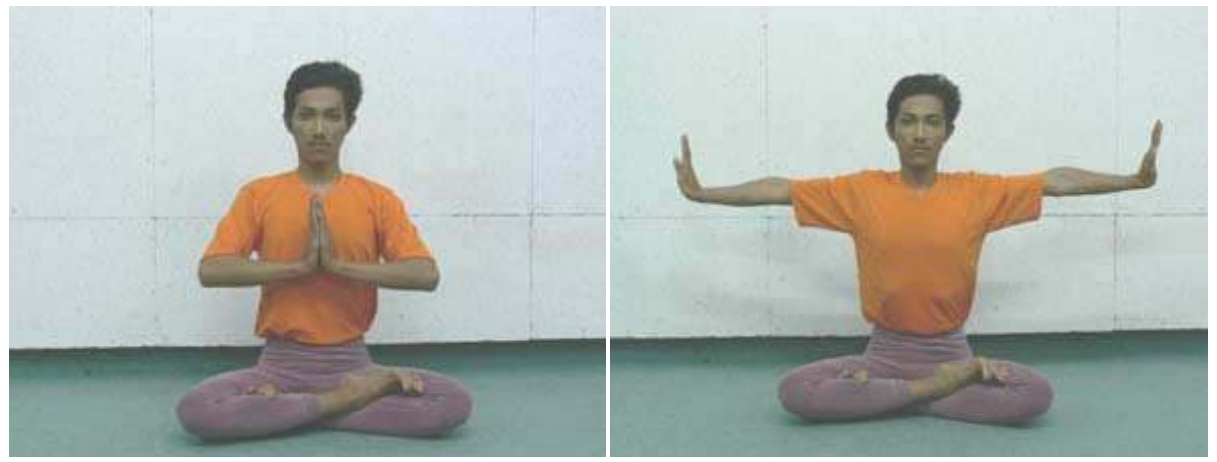

Gambar Pose garuda

PAVARTASANA (POSE GUNUNG)

a. Posisi duduk kaki dilipat saling menumpuk, tangan diangkat lurus di atas kepala. Ketika mengangkat tangan diiringi dengan menarik nafas.

b. Condongkan badan ke kanan sambil menahan nafas.

C. Posisi tubuh lurus kembali dan menurunkan tangan sambil menghembuskan nafas.

d. Ulangi lagi posisi dan gerak tersebut tetapi sekarang badan condong ke kiri. Lakukan secara bergantian sebanyak 8 kali ke kanan dan kiri.

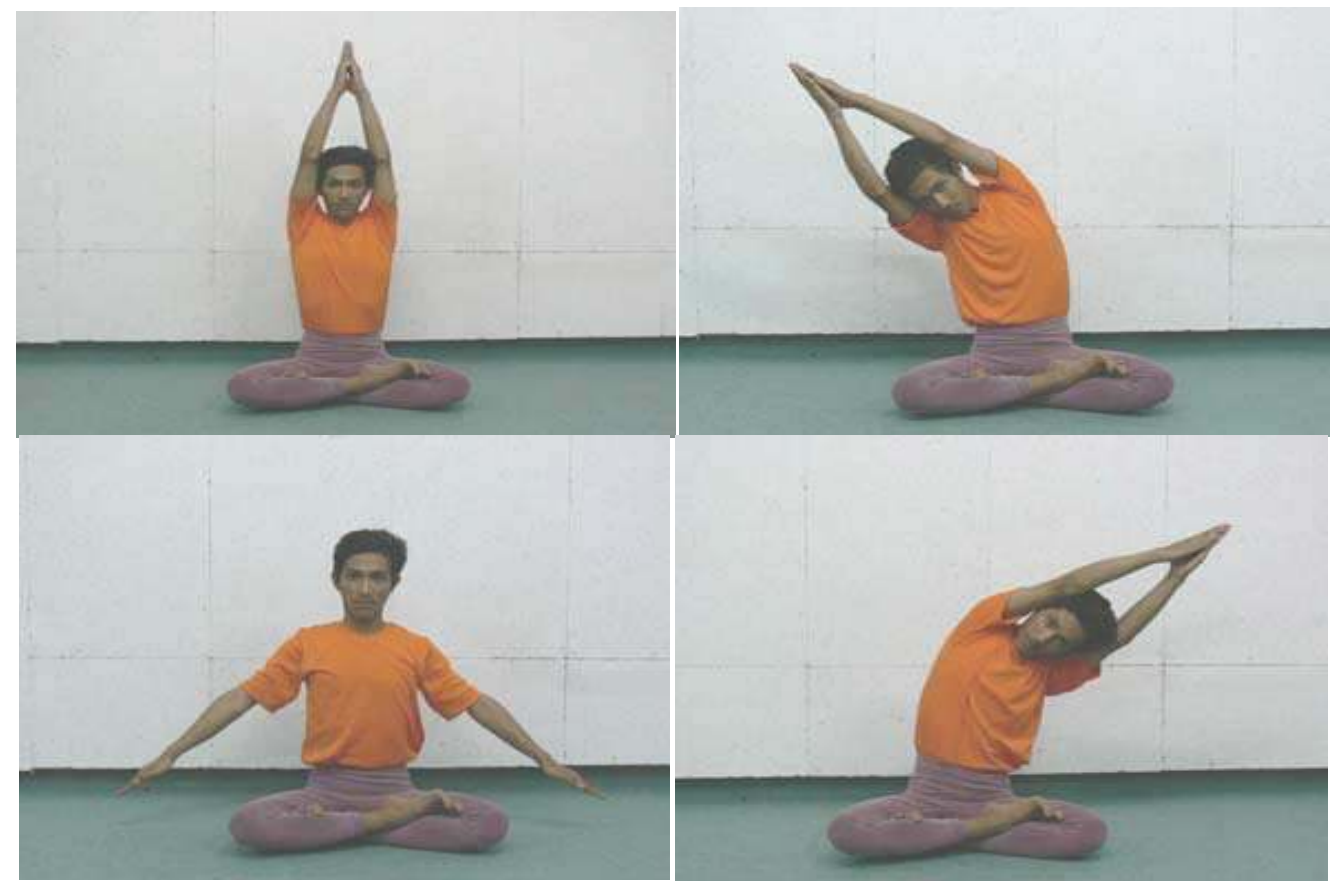

Gambar Pose gunung 
a. Posisi duduk dengan kaki sebagai alas, tarik nafas, dan tahan.

b. Posisi sujud dengan tangan membentuk segi tiga di samping kepala, pelanpelan angkat badan dan kaki ke atas sampai lurus.

c. Posisi terbalik (kepala di bawah dan kaki di atas) hembuskan nafas. Pada posisi ini kita bernafas segi tiga yaitu tarik, tahan, hembuskan.

d. Pada awalnya lakukan hanya beberapa menit tetapi semakin sering dilakukan, hitungan waktunya semakin ditambah.

e. Kalau belum ada keseimbangan minta bantuan teman untuk memegangi kaki.

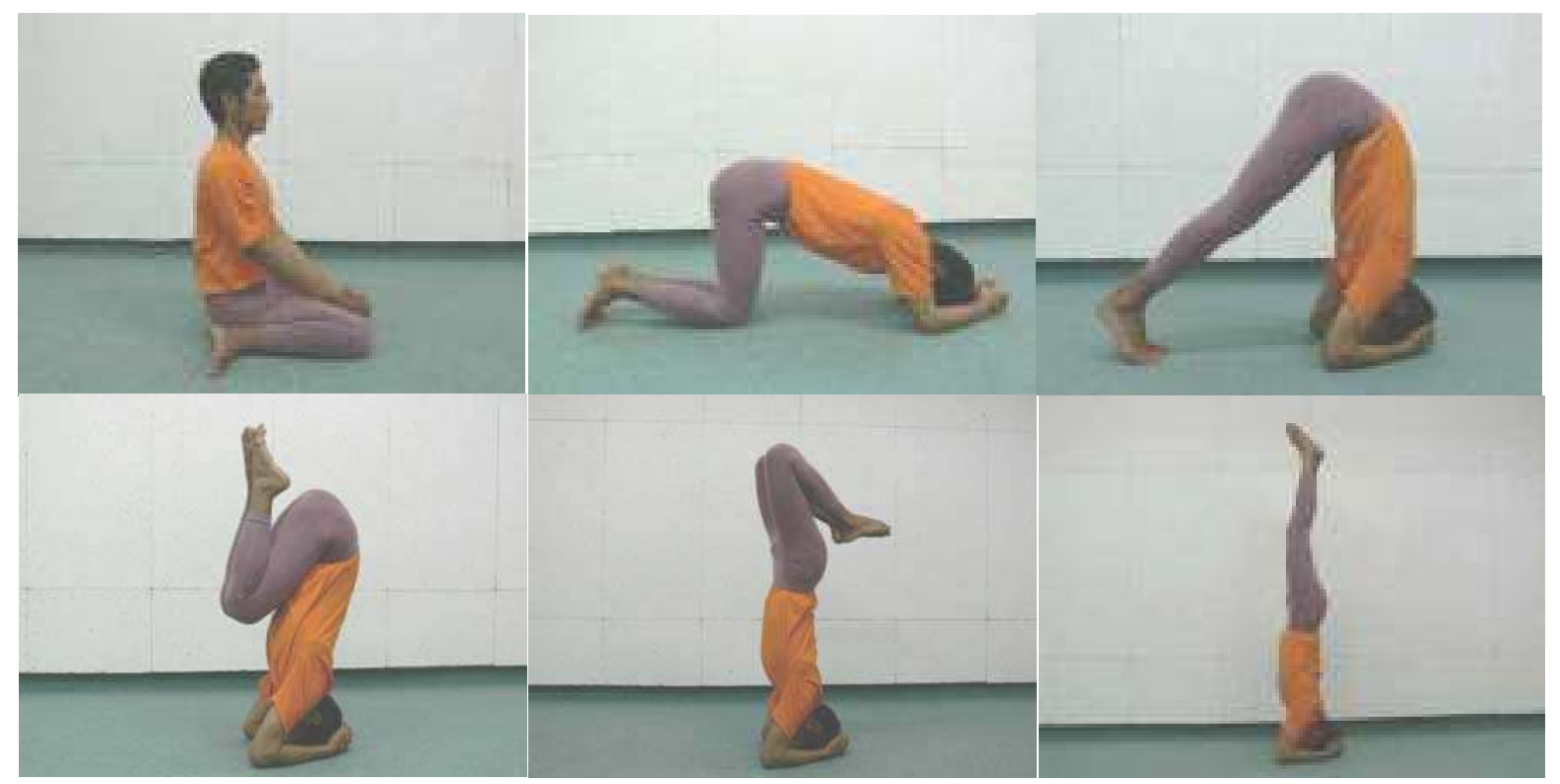

Gambar Pose sirshasana

\section{SARVANGASANA}

a. Posisi tidur terlentang dengan tangan di samping badan, terus angkat kaki ke atas sambil menghirup udara.

b. Posisi berdiri pada pundak dan leher. Nafas ditahan dan hembuskan. Pernafasan menggunakan pernafasan segitiga.

c. Lakukan yoga ini mulai dari waktu yang pendek sampai waktu yang panjang. 

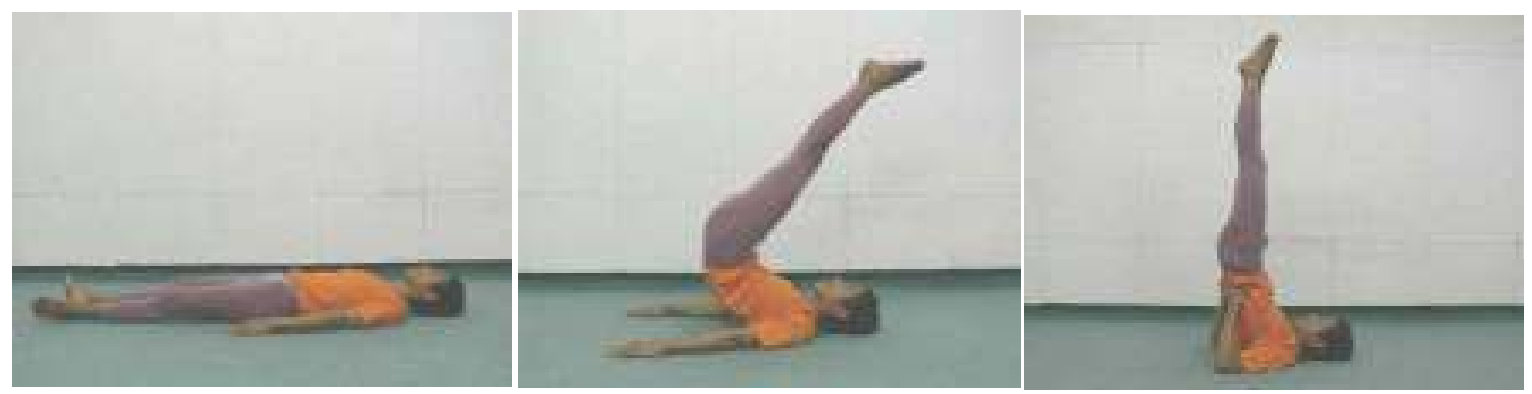

Gambar Pose sarvangasana

MATYASANA (POSE IKAN)

a. Posisi duduk dengan kaki dilipat saling menumpuk, tangan di samping badan, diteruskan merebahkan diri dengan kaki masih saling terkait.

b. Tangan yang di samping badan terus mengangkat pinggang agar kedudukan dada lebih tinggi. Tangan setelah mengangkat kemudian dipakai sebagai alas kepala.

c. Lakukan dengan pernafasan segitiga sebanyak 10 - 15 kali pernafasan.
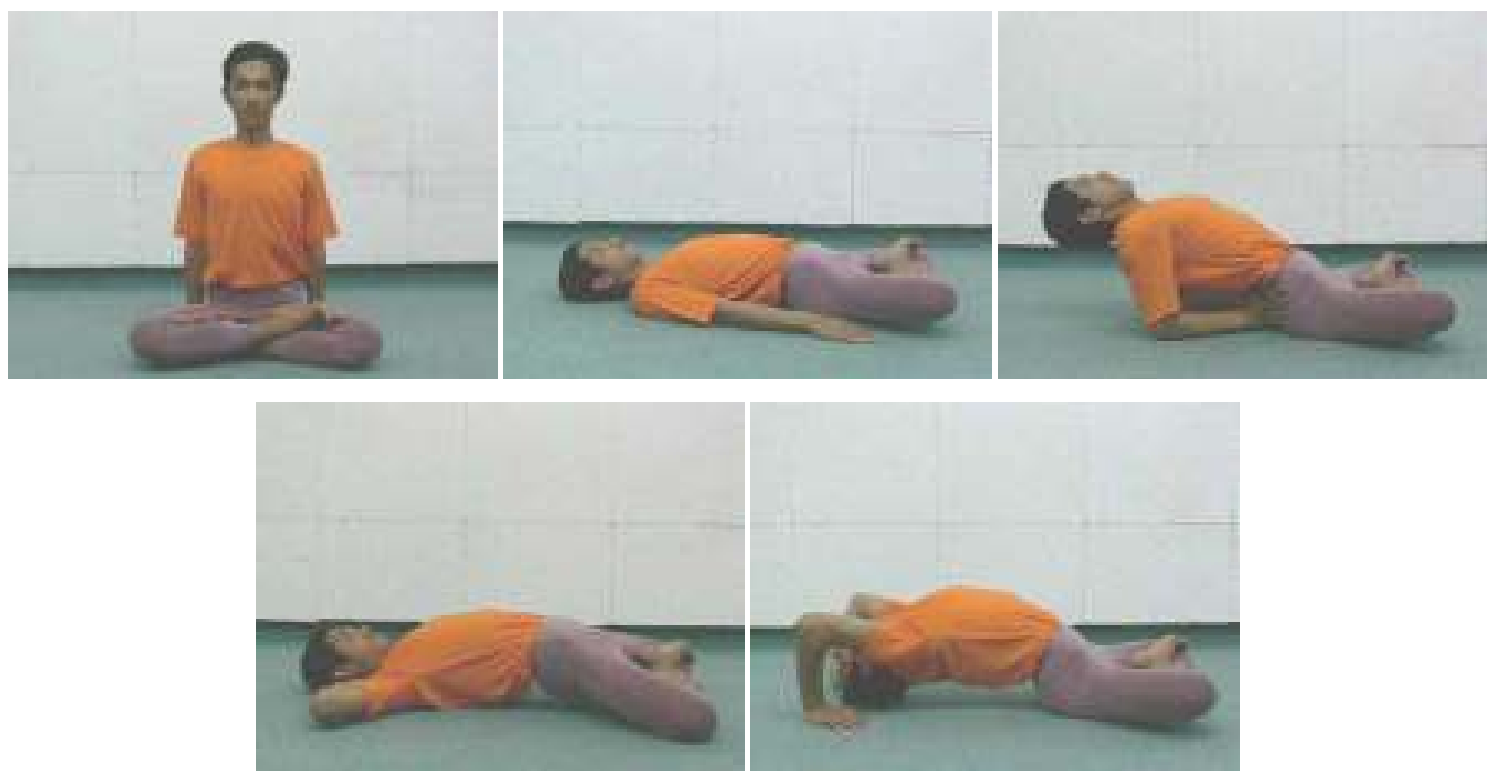

Gambar Pose ikan 
a. Posisi tubuh telungkup rata dengan lantai, kedua tangan santai di samping badan dan menghirup nafas.

b. Angkat kaki kanan ke atas dan nafas ditahan. Ketika kaki diturunkan maka nafas dihembuskan

c. Lakukan dengan kaki secara bergantian.

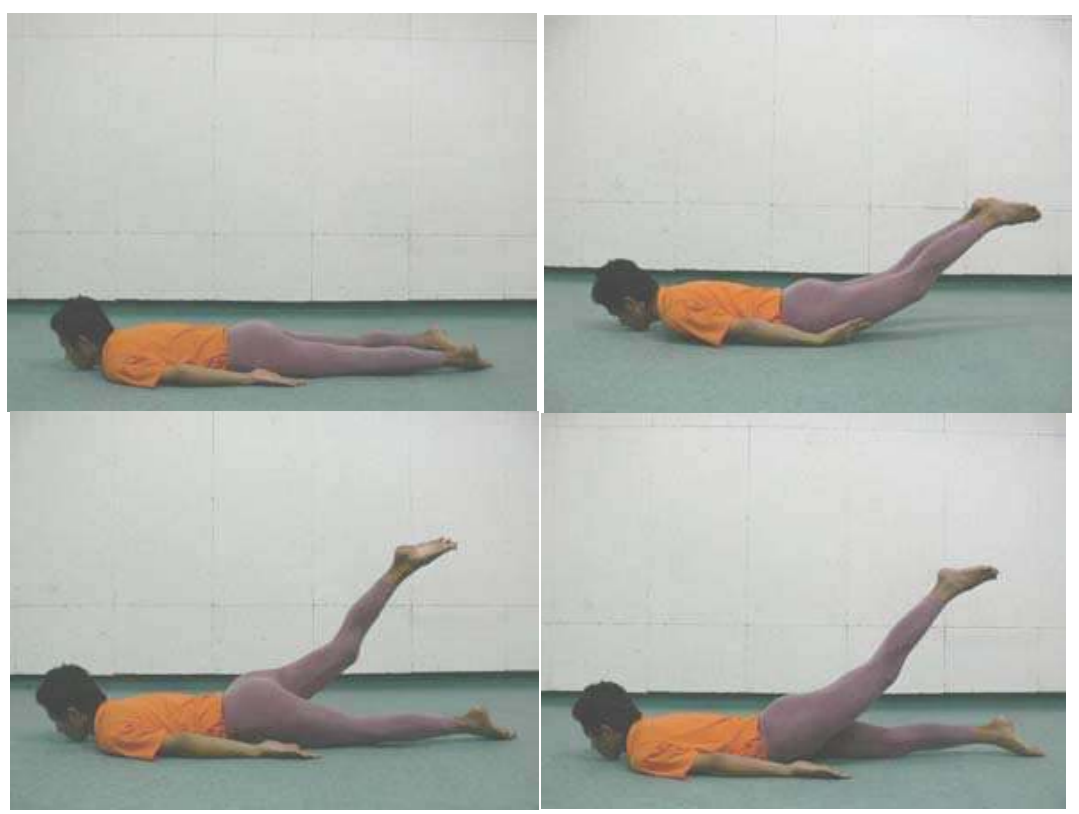

Gambar Pose belalang

\section{BHUJANGASANA (POSE COBRA)}

a. Posisi tubuh telungkup rata dengan lantai, tangan dilipat di samping badan.

b. Tangan mendorong dada dan kepala tegak. Dorongan ini diusahakan sampai tangan tegak lurus. Ketika tangan mendorong kita menghirup nafas terus ditahan. Ketika tangan diturunkan kita menghembuskan nafas.

c. Lakukan sampai 10 - 15 kali nafas. 

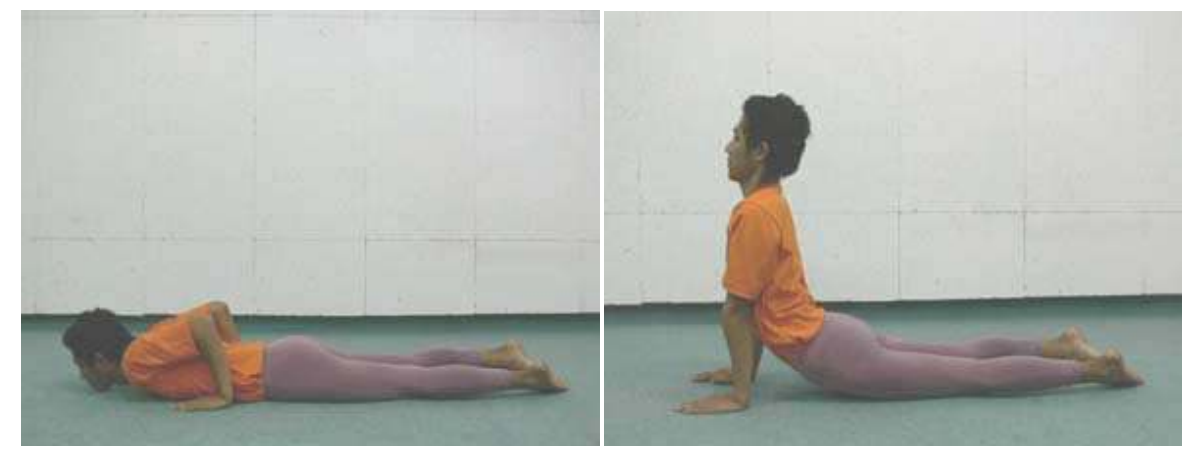

Gambar Pose cobra

\section{SURYANAMASKAR (POSE HORMAT PADA CAHAYA)}

a. Posisi berdiri, tangan posisi menyembah di dada, dan menghirup nafas panjang.

b. Tangan dibuka dan ayunkan ke belakang sambil menahan nafas.

c. Tangan diayunkan ke depan sampai menyentuh lantai sambil menghembuskan nafas.

d. Posisi jongkok dan kaki kiri ditarik ke belakang sedangkan kedua tangan menahan berat tubuh sambil menghirup nafas panjang.

e. Posisi push-up sambil menahan nafas.

f. Posisi push-up yang diturunkan hanya pada tangan sambil menghembuskan nafas.

g. Posisi tubuh diteruskan dengan pose kobra sambil menarik nafas panjang.

h. Pose kobra dan menarik pinggul ke atas sehingga tangan dan kaki dalam keadaan lurus sambil menahan nafas.

i. Kaki kanan dimajukan sampai tertekuk turun sambil menghembuskan nafas.

j. Bangkit sampai seperti posisi ketiga sambil menghirup nafas.

k. Posisi bangkit dan tangan diangkat ke atas sampai belakang sambil menahan nafas.

l. Posisi berdiri dan menurunkan tangan sammbil menghembuskan nafas. Lakukan latihan sebanyak 8 kali. 


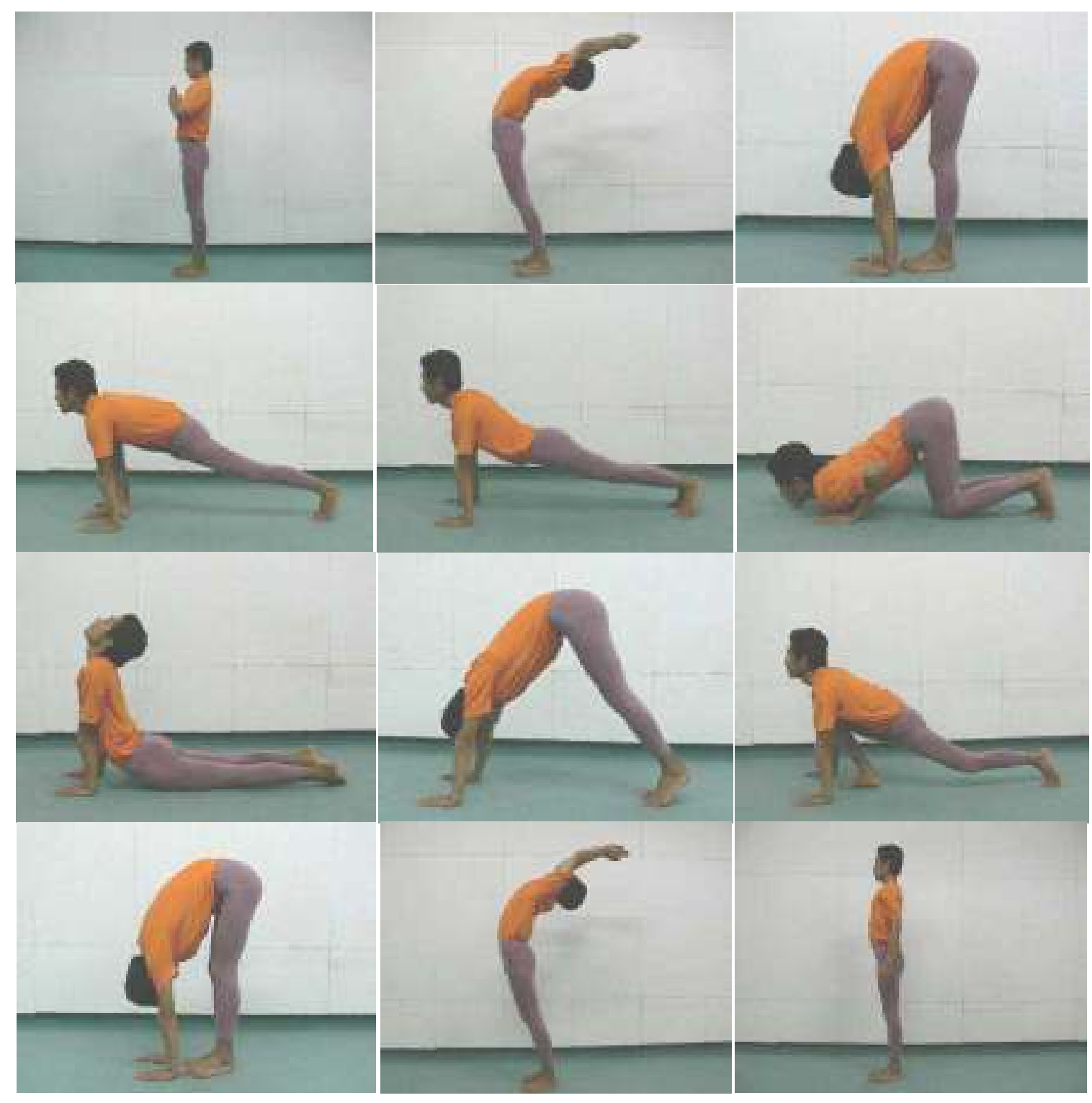

Gambar Pose suryanamaskar 